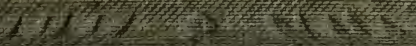

ist? (a) 251 g.
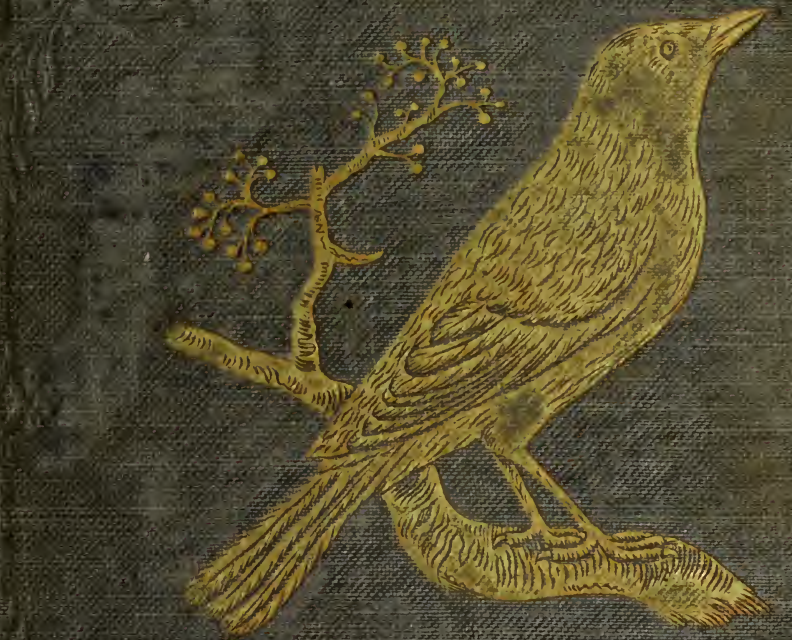

$\sqrt{10}$

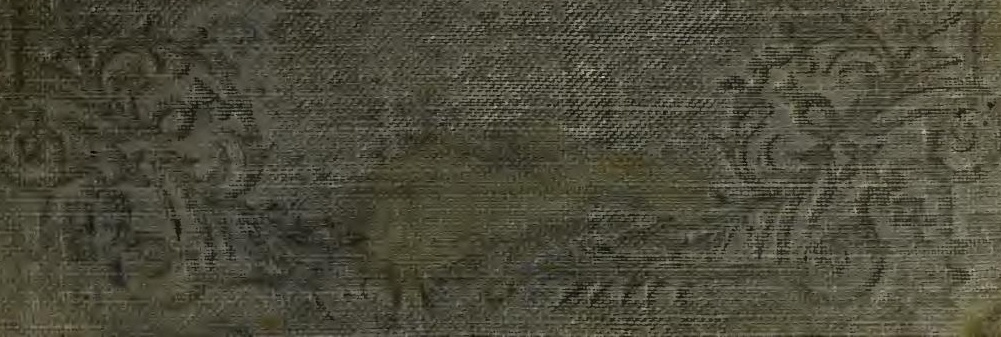




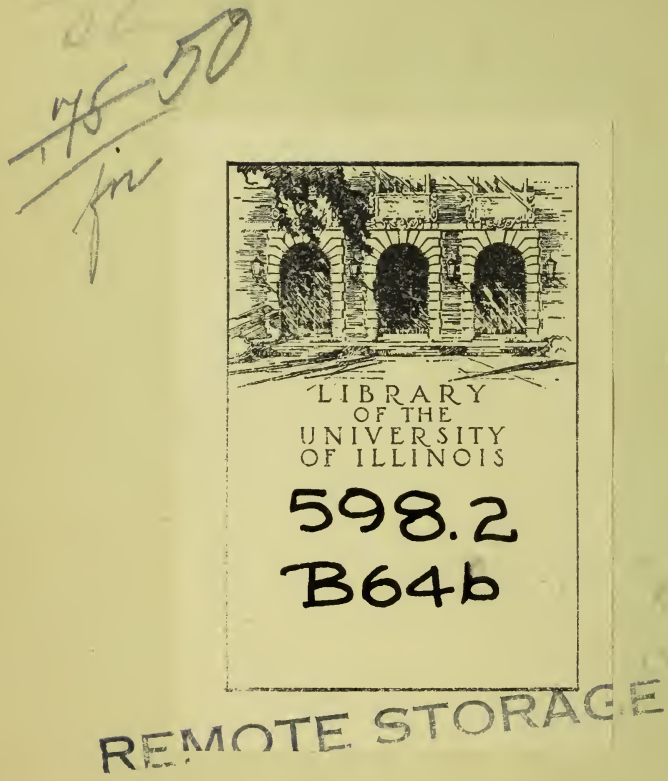




\section{Return this book on or before the Latest Date stamped below.}

COT 191958

MYY 14 


\section{Digitized by the Internet Archive in 2016 with funding from}

University of Illinois Urbana-Champaign Alternates 


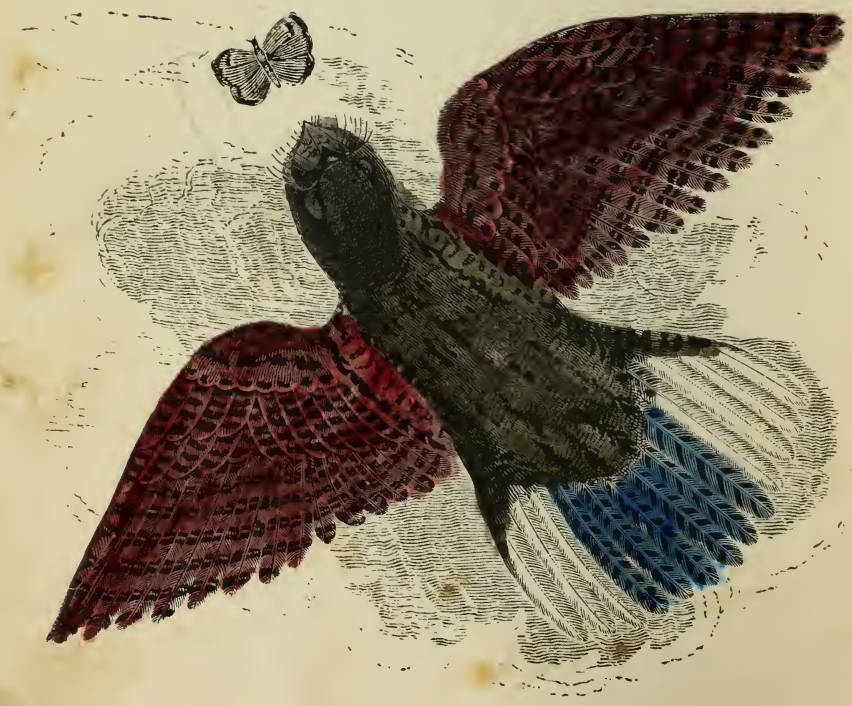


T Н $\mathbf{E}$

\title{
B00K OF BIRDS;
}

INTENDED FOR THE AMUSEMENT AND INSTRUOTION

\author{
or

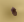 \\ YOUNG PEOPLE.
}

ILLUSTRATED WITH SIXTEEN ELEGANT PLATES,

PHILA D E P I I A :

GEORGE S. APPLETON, 164 CHESTNUT ST.

NEW YOR K :

D. APPLETON \& CO., 200 BROADWAY.

1850. 
Entered according to Act of Congress, in the yoar 1849, by

GEO. S. A P P LET ON,

in the Clerk's Office of the District Court of the United States, in and for the Fastern District of Pennsylvania. 


\section{2 \\ B646}

\section{OF BIRDS.}

No class of the animal kingdom is more interesting than BIRDs. Their infinite variety of form, habits, and manners ; their plumage, always beautiful, often rich and gorgeous; their powers of flight and grace of motion, their curious nests, their varied music ; the bittern's boom, the cawing of the busy rooks, the cock's shrill clarion, the capricious lay of the mocking-bird, or the sweet warbling of the oriolenay, even the hoarse cries of the sea-birds, and the garrulous clucking of the barn-fowls-these all combine to endear us to the feathered creation, since all are appropriate-all are the voice of Nature. The birds are associated with many delightful scenes dear to memory.

Who sees the swallow on his first return and dreams not 
vi

of spring in times long past? Who hears the song of the blue bird or the bob-o-link without a delightful reminiscence of school-boy days, ready to repeat with Wordsworth :

\section{"And I can listen to thee yet, And lie upon the plain; And listen till I do beget That golden time again."}

Hence it is that, although all birds are interesting, the birds of our own country are most attractive. We have marked their ways; we have watched them building their nests and rearing their young; we have listened to their ringing notes when "creeping like snail unwillingly to school," and longing for a ramble in the fields. They are associated with all our rural pleasures, all our holiday sports; and we love them for their being indissolubly linked in our memories with a happy past.

The characteristics which distinguish birds from the other classes of vertebrated animals, are that they lay eggs, from which their young are hatched by what is called incubation; their skins are covered with feathers, and their jaws are horny, without teeth. Their blood is warm and circulates 
like that of the Mammalia. The six orders of birds, are as follows :

1. Raptores, or birds of prey. These birds are distinguished by a very strong and sharp bill more or less curved, but always hooked at the extremity of the upper mandible, which is covered at the base with a kind of skin called the cere. The nostrils are usually open. The legs are very strong, and generally only partially covered with feathers; the feet are large, and the toes, which are four in number, are armed with very strong, sharp, curved, prehensile claws. The principal raptorial birds are the vultures, including the condor; the falcon family, including the eagles, hawks, kites, and buzzards; and the owls.

2. Insessores, or perching birds. These birds have all feet formed for perching, the hind toe springing from the same place as the other toes, which gives them great power of grasping. Their legs are of moderate length, and their claws not sharply curved. This order includes the thrushes, nightingales, and all the finest songsters of our groves, with the robin-redbreast, the sparrow, and other birds seen about dwellings, the swallows, the larks, the crow family, the kingfishers, the birds of paradise, and the humming birds. 
3. Scansores, or climbers. These birds have two toes before and two behind, or rather they have the power of throwing one of the fore toes back at pleasure. This construction gives them such great power of climbing, that they can ascend the perpendicular trunk of a tree. The principal birds in this order are the parrot family and the woodpeckers.

4. Rasores, or gallinaceous birds. These birds have the head small in proportion to the body. The bill is generally short, with the other mandible somewhat curved, and furnished with a cere. The nostrils have usually a protecting fleshy membrane. The tarsus, or lower part of the leg, is long and bare, and there are four toes, those in front being united by a slight membrane, while that behind is generally higher up the leg, and smaller than the others. This order comprises nearly all the birds used as food, and it includes the peacock, the turkey, the common cock and hen, the partridge, the pheasant, and the pigeon family.

5. Grallatores, or Waders. These birds are characterized by their long and slender legs, and generally bare thighs. Their feet have generally three toes, more or less united at the base by a web, and the central toe is often longer and 
stronger than the rest; the hind toe is sometimes wanting. This order contains the ostrich family, the bustards and plovers ; the cranes, herons, and storks ; and the snipes and woodcocks.

6. Palmipedes, or web-footed birds. These birds have the legs and feet short, and placed behind, with their fore toes united by a thick and strong membrane. The neck is much longer than the legs, and their bodies are covered with a dense layer of down, beneath the outer plumage, which is close, and imbued with an oily fluid that repels the water. The principal birds in this order are the coots and grebes, the auks and penguins, the petrels, the pelican and cormorant, and the swans, ducks, and geese.

Not only does the form of the bird fit it for flying, but its lungs are extended by means of air-cells extending among the muscles; and its bones are hollow, and not filled with marrow, but with air. Other circumstances in their internal structure serve to fäcilitate the flight of birds, and to make them quite at ease when on the wing.

In variety birds far exceed quadrupeds. There are many thousand species, distinguished from each other by differ- 
ences of configuration, colour, and habits; but the grand distinctions are so few that a tolerably correct idea of this part of the animal kingdom may be formed, even by such a general and succinct view as that which we propose to give to the reader; and we hope, by enlivening our descriptions with occasional illustrative anecdotes, to render our account interesting as well as instructive. 


\section{CONTENTS.}

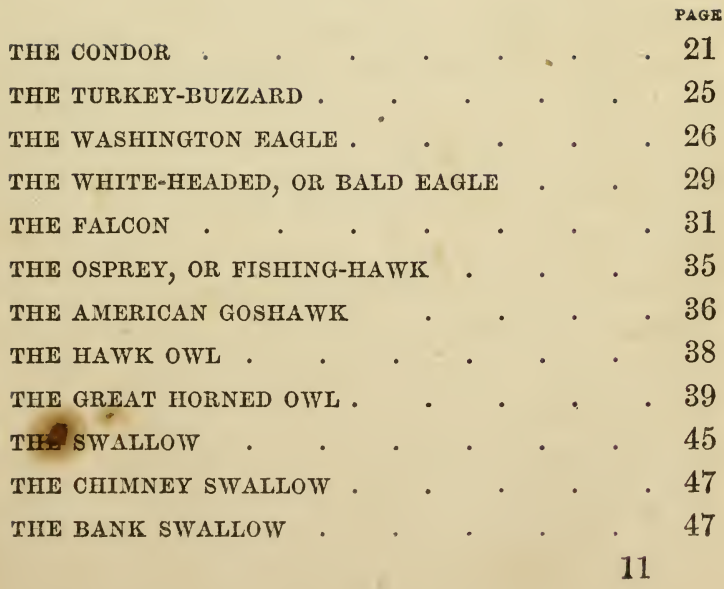


THE BALTIMORE ORIOLE . . . . 48

THE ROBIN • . . . . . . . 52

THE NIGHTINGALE • • • . - . 55

THE RED-WINGED BLACKBIRD, OR TROOPIAL . 58

THE SKYLARK . • . . . • • 62

THE CARDINAL BIRD . . . . . 64

THE MOCKING-BIRD . . . . . 67

THE CROW . . . . . . . 70

THE WHIP-POOR-WILL . . . . 74

THE CUCKOO

THE KINGFISHER . . . . . . 78

THE GREEN WOODPECKER . . . . 79

THE TOUCAN . $\quad . \quad$. $\quad . \quad$. $\quad$. 79

THE CAROLINA PARROT. . . . . 80

THE PEACOCK . . . . . . . 85

THE TURKEY .

THE PINTADO, OR GUINEA HEN . • • . 87

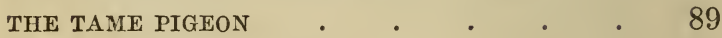

THE OSTRICH • . . . . . . 90

THE CASSOWARY . . . . . . . 93

THE WHOOPING CRANE . . . . . 94

THE BLACK-NECKED STILT . . . . 97 
THE FLAMINGO

WILSON'S STORMY PETREL,

THE PIED OYSTER-CATCHER . . . . 105

THE GREAT HERON

THE WOOD IBIS

THE SNOW GOOSE .

THE WANDERING ALBATROSS •

THE SWAN

THE CINEREOUS COOT

THE SUMMER, OR WOOD DUCK

THE COMMON DUCK, OR MALIARD

THE CANVASS-BACK DUCK

THE PELICAN .

THE CORMORANT .

THE BLACK AND WHITE GULL .

THE GREAT TERN .

THE PURPLE GALLINULE -
THE GREAT NORTHERN DIVER, OR LOON

THE BLACK-HEADED GULL

THE EIDER DUCK .

THE CANADA GOOSE .

THE SKUA GUIL . 


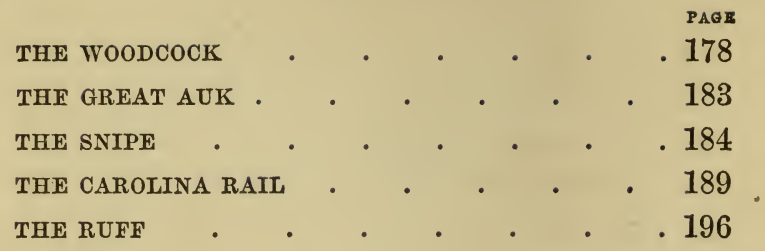





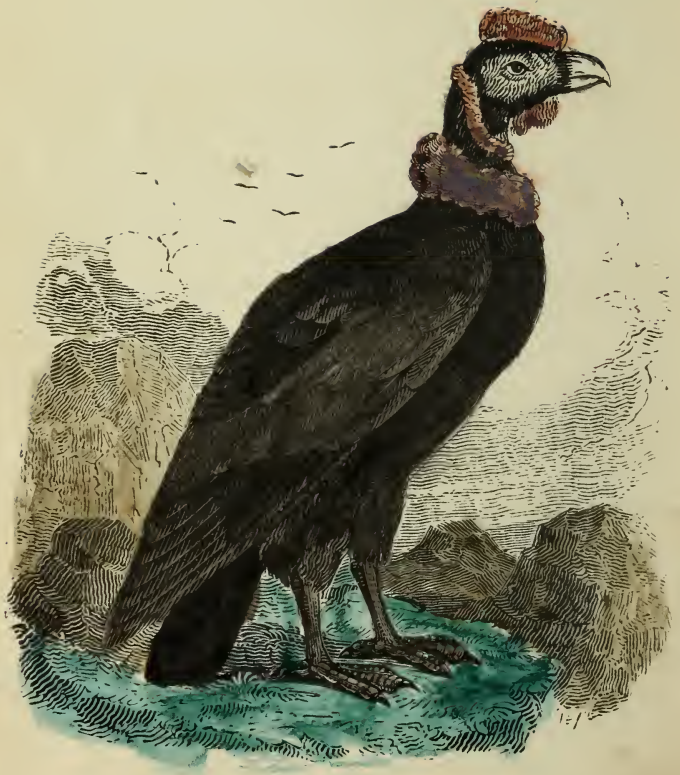


THE

\section{B00K 0F BIRDS.}

\section{THE CONDOR. (Sarcoramphus gryphus.)}

The first order of birds, Raptores, includes Vultures, Falcons, and Owls. They are distinguished by a strong curved bill, fitted for tearing flesh, having on each side towards the end a projection, like a tooth; the base is frequently covered with a naked membrane, called a cere; the legs are short, and the claws sharp-pointed and considerably curved. It is a remarkable fact that the females of birds of prey, unlike those of the other orders, are rather larger and more powerful than the males.

The Vultures generally have no feathers on the head and upper part of the neck, a peculiarity which enables them to feed more easily on carrion, which is their favourite food. Of these the most remarkable is the Condor. Mr. Nuttall says that the Condor derives its name from an Indian word which alludes to its supposed sagacious scent. 
It inhabits the whole chain of the Andes of Mexico, Peru, Chili, and Patagonia to the Straits of Magellan, and, on the authority of Lewis and Clarke, they are sometimes seen in the range of the Rocky Mountains, towards the sources of the Missouri. Their peculiar residence is the great chain of the high Andes, where they associate three or four together upon the points of cliffs without either fearing or injuring men, so that they may be approached within four yards without showing alarm, or making on their part any attempt at attack. Hardly an instance is really known of their even assaulting an infant, though some credulous naturalists, with the exaggerating privilege of travellers, have given accounts of their killing young persons of ten or twelve years of age. Their ability for such rapine is not to be doubted, but their natural cowardice forbids the attempt. At the same time, it is not uncommon to see them follow and hover around a young bull until they have torn out his eyes and tongue.

A pair of Condors will not only in this way attack the deer of the Andes, the puma or American lion (our panther), the vicogne, and the llama (or American camel), but also the wild heifer. They will pursue it for a long time, occasionally wounding it with their bill and claws, until the unfortunate animal, now stifled and overcome with fatigue, extends its tongue and groans; on which occasion the Condor seizes this member, being a very tender and favorite morsel, and tears out the eyes of his prey, which at 
length falls prostrate to the earth and slowly expires. The Condor then gorges himself, and rests in stupidity, and almost gluttonous inebriation, perched upon the highest neighbouring rocks. The formidable hunter, now loaded with his meal, may be driven about without his attempting to fly; and in this state the Indians sometimes pursue them with the lasso or noose, and easily take them captive. Thus restrained, the Condor makes extraordinary efforts to rise into the air; but fatigued by the attempt, he begins to disgorge himself freely, an effort he appears to assist by lengthening and shortening the neck, and bringing forward the sheath of his beak. They will approach dwellings when allured by the scent of food; and a dead animal will draw down a crowd of these gluttons, where none at the time are at all visible; they tear and eat with the greatest voracity, pushing sometimes with their feet, and flapping their wings.

They make no nest, but deposit their eggs upon the naked rock; these are two, wholly white, and three or four inches in length. It is said that the female remains with her young for the space of a year. The young Condor has no feathers. His body, for several months, is covered only with a very fine down or whitish frizzled hair, which resembles that of young owls. This down disfigures the young bird so much, that in this state it appears almost as large as an adult.

The size of the Condor has been greatly exaggerated. It 
seldom exceeds three feet in length and nine and a half feet in extent.* The tail one foot two inches. The bill is straight and hooked at the point; the plumage is white in front, everywhere else of a brownish gray; head bare of feathers and covered with hard wrinkled skin, scattered over with blackish hairs, and it has a collar of white silky down between the bare and the feathered part of the neck. The feet are stout, and the nails long and crooked.

\section{ILLUSTRATIVE ANECDOTES.}

Sir Francis Head, in his gallop across the Pampas, and his visit to the Andes, frequently encountered Condors. He relates the account of a struggle between one of his Cornish miners and a Condor gorged with food, and therefore not in the best state for a fray. The man began by grasping the bird round the neck, which he tried to break; but the bird, roused by the unceremonious attack, struggled so violently as to defeat the plan; nor, after an hour's struggling, though the miner brought away several of the wing-feathers in token of victory, does it appear that the bird was despatched.

The Condor is not only captured with the lasso, but he is taken by various traps and stratagems. According to Mr. Darwin, the Chilenos are in the habit of marking the trees

* The term extent, applied to the description of birds, means the distance from tip to tip of the extended wings. 
in which they roost, frequently to the number of five or six together, and then at night climbing up and noosing them. They are such heavy sleepers that this is not a difficult task. Lieutenant Maw saw the Condor's quill used as a pen in the Cordillera.

\section{THE TURKEY-BUZZARD. (Vultur aura.)}

THERE are many species of Vultures distributed over the various parts of the world, chiefly in the warmer countries, where they are considered very serviceable in consuming the carcasses of dead animals, which would otherwise taint the air. The King Vulture, found in South America and Mexico, and the California Vulture, found on our western coast, are among the American species; but of these the most common, and therefore the most interesting, is the Turkey-Buzzard, which abounds in our Southern States and in the West Indies, where they are commonly protected for their services as scavengers of carrion. In the winter they generally seek out warmth and shelter, hovering often like grim and boding spectres in the suburbs, and on the roofs and chimneys of the houses around the cities of the Southern States.

Mr. Nuttall describes the Turkey-Buzzard as follows:

The Turkey Vulture is about two and a half feet in 2 
length, and six in breadth. Eyes dark or reddish-hazel. The head and neck for about an inch and a half below the ears, furnished with a reddish wrinkled skin, and some tints of blue, sprinkled with short black hairs. From the hind-head to the neck-feathers the space is covered with a black down. The fore-part of the neck is bare to the breast-bone. The plumage of the neck is large and tumid, and, with that of the back and shoulders, nearly black; almost all the rest of the body is of the same colour, in parts inclining to brown. Third primary longest. The wings extend to the end of the tail. The upper plumage is generally glossed with green and bronze, having purplish reflections. Legs feathered to the knees; the feet somewhat webbed. The bill nearly white, often tipped with bright olive green. Weight from four and a half to five pounds.

\section{WASHINGTON EAGLE. (Falco Washingtonii.)}

THIS splendid bird is found in the mountain regions of Kentucky. It is the largest of all the Eagle tribe. Its length is three feet seven inches; extent of wings ten feet two inches; bill three inches and a quarter. Length of wing when folded thirty-two inches; length of tail fifteen inches; middle claw four inches and three-quarters; hind 


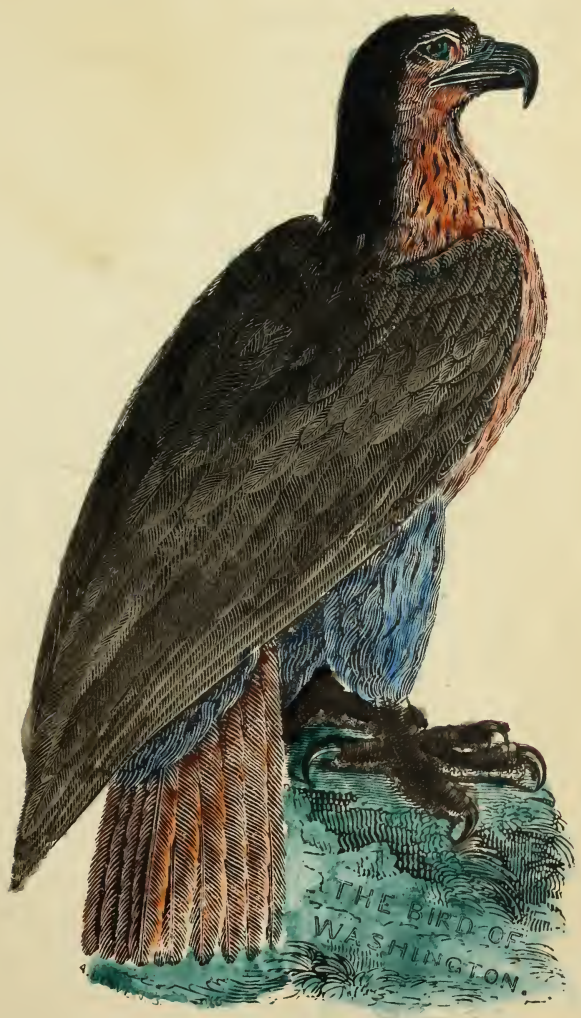


<smiles>CCCCCCC</smiles> 
claw two inches and a half. The upper parts of the body are dark, shining, coppery-brown; throat, front, and breast, rich bright cinnamon colour. The whole appearance of the bird grand and majestic.

\section{ILLUSTRATIVE ANECDOTES.}

Mr. Nuttall says, "It is to the indefatigable Audubon, that we owe the distinct notice and description of this noble Eagle, which first drew his attention while voyaging far up the Mississippi, in the month of February, 1814. At length, he had the satisfaction of discovering its eyry in the high cliffs of Green River in Kentucky, near to its junction with the Ohio; two young were discovered loudly hissing from a fissure in the rocks, on the approach of the male, from whom they received a fish. The female now also came, and with solicitous alarm for the safety of her young, gave a loud scream, dropped the food she had brought, and hovering over the molesting party, kept up a growling and threatening cry by way of intimidation; and, in fact, as our disappointed naturalist soon discovered, she from this time forsook the spot, and found means to convey away her young. The discoverer considers the species as rare ; indeed, its principal residence appears to be in the northern parts of the continent, particularly the rocky solitudes around the great north-western lakes, where it can at all times collect its finny prey, and rear its young without the dread of man. In the winter season, about January and February, as well 
as at a later period of the spring, these birds are occasionally seen in this vicinity,* rendered perhaps bolder and more familiar by want, as the prevalence of the ice and cold, at this season, drives them to the necessity of wandering further than usual in search of food. At this early period, Audubon observed indications of the approach of the breeding season. They are sometimes seen contending in the air, so that one of the antagonists will suddenly drop many feet downwards as if wounded or alarmed. My friend, Dr. Hayward of Boston, had in his possession one of these fine docile Eagles for a considerable time; but desirous of devoting it to the then Linnæum Museum, he attempted to poison it, by corrosive sublimate of mercury; several times, however, doses even of two drams were given to it concealed in fish, without producing any injurious effect on its health.

"The Washington Eagle, bold and vigorous, disdains the piratical habits of the Bald Eagle, and invariably obtains his own sustenance without molesting the osprey. The circles he describes in his flight are wider than those of the White-headed Eagle; he also flies nearer to the land or the surface of the water; and when about to dive for his prey, he descends in circuitous, spiral rounds, as if to check the retreat of the fish, on which he darts only when within the distance of a few yards. When his prey is obtained, 
he flies out at a low elevation to a considerable distance to enjoy his repast at leisure.

"The quantity of food consumed by this enormous bird is very great, according to the account of those who have had them in confinement. Mr. Audubon's male bird weighed fourteen and a half pounds avoirdupois. One in a small museum in Philadelphia (according to the account of my friend Mr. C. Pickering), also a male, weighed much more, by which difference it would appear that they are capable of becoming exceedingly fat; for the length of this bird was about the same as that of Audubon, three feet six or seven inches. The width, however, was only about seven feet, agreeing pretty nearly with a specimen now in the New England Museum. The male of the Golden Eagle, the largest hitherto known, is seldom more than three feet long."

\section{THE WHITE-HEADED, OR BALD EAGLE.}

(Haliætus leucocephalus.)

THIs bird is about three feet long, and seven feet broad from tip to tip of the wings. The bill resembles that of the golden eagle, and from the chin hang some small hairy feathers like a beard. As it is found alike in regions of excessive cold and in the torrid zone, it is provided for 
enduring rapid changes of temperament, and its whole body is clothed under the feathers with a kind of down, white and soft like that of the swan. This bird builds its nest on some romantic cliff by the sea-shore, or on the bank of some river or lake, and feeds almost entirely upon fish.

It is generally regarded by our countrymen with peculiar respect, as the chosen emblem of our native land. The great cataract of Niagara is mentioned as one of its favourite places of resort, not merely as a fishing station, where it is enabled to satiate its hunger upon its most congenial food, but also in consequence of the vast quantity of four-footed beasts, which unwarily venturing into the stream above, are borne array by the torrent, and precipitated down those tremendous falls.

High o'er the watery uproar silent seen,

Sailing sedate in majesty serene,

Now 'midst the pillar'd spray sublimely lost,

And now emerging, down the rapids toss'd,

Glides the Bald Eagle, gazing calm and slow

0 'er all the horrors of the scene below;

Intent alone to sate himself with blood,

From the torn victims of the raging flood.

The number of birds of prey of various kinds, which assemble at the foot of the rocks to glut themselves upon the banquet thus provided for them, is said to be incredibly great, but they are all compelled to give place to the Eagle when he deigns to feed on dead animals; and the crow and 
the vulture submit without a struggle to the exercise of that tyranny, which they know it would be in vain to resist.

\section{ILLUSTRATIVE ANECDOTES.}

"We have ourselves," says Wilson, "seen the Bald Eagle, while seated on the dead carcass of a horse, keep a whole flock of vultures at a respectful distance, until he had fully sated his own appetite :" and he adds another instance, in which many thousands of tree squirrels having been drowned, in one of their migrations, in attempting to pass the Ohio, and having furnished for some length of time a rich banquet to the vultures, the sudden appearance among them of the Bald Eagle at once put a stop to their festivities, and drove them to a distance from their prey, of which the Eagle kept sole possession for several successive days.

\section{THE FALCON. (F'alco communis.)}

THE Falcon is a predaceous bird, of which there are several species. The Gerfalcon is the largest, and it is found in the northern parts of Europe; and, next to the eagle, it is the most formidable, the most active, and the most intrepid of all voracious birds, and is the dearest and most esteemed for falconry. The bill is crooked and yel- 
low; the irides of the eye dusky; and the whole plumage of a whitish hue, marked with dark lines on the breast, and dusky spots on the back.

The Peregrine Falcon, which is the most common kind, is as large as the moor buzzard. The bill is blue at the base, and black at the point; the head, back, scapulars, and coverts of the wings are barred with deep black and blue; the throat, neck, and upper part of the breast are white, tinged with yellow; the bottom of the breast, belly, and thighs are of a grayish white; and the tail is black and blue.

Wilson enumerates no less than ten varieties, dependent chiefly upon age, sex, and country. It is found, more or less abundantly, throughout the whole of Europe, principally in the mountain districts in North, and probably South America, and in New Holland, dwelling in the clefts of rocks, especially such as are exposed to the mid-day sun. It breeds upon the cliffs in several parts of England, but appears to be more common in Scotland and Wales. Its food consists principally of small birds; but it scruples not to attack the larger species, and sometimes gives battle even to the kite.

Falcons rarely take their prey upon the ground, like the more ignoble birds of the class to which they belong; but pounce upon it from aloft, in a directly perpendicular descent as it flies through the air, bear it downwards by the united impulse of the strength and rapidity of their attack, 
and sticking their talons into its flesh, carry it off in triumph to the place of their retreat. Like most predatory animals, they are stimulated to action by the pressure of hunger alone, and remain inactive and almost motionless while the process of digestion is going on, and until the renewed cravings of their appetite stimulate them to further exertion.

In different stages of its growth, the Peregrine Falcon has been known by various English names. Its proper appellation among falconers is the Slight Falcon, the term Falcon Gentle being equally applicable to all the species when rendered manageable. In the immature state, this Falcon is also called a Red Hawk, from the prevailing colour of its plumage. The male is called a Tiercel, to distinguish it from the female, which, in the Falcon tribe, is most commonly one-third larger than the male.

\section{ILLUSTRATIVE ANECDOTES.}

In China there is said to be a variety which is mottled with brown and yellow. These birds are said to be used by the emperor of China in his sporting excursions, when he is usually attended by his great falconer, and a thousand of inferior rank. Every bird has a silver plate fastened to its foot, with the name of the falconer who has the charge of it, that, in case it should be lost, it may be restored to the proper person; but if it should not be found, the name is delivered to another officer, called the guardian of 


\section{4}

THE FALCON.

lost birds, who, to make his situation known, erects his standard in a conspicuous place among the army of hunters.

In Syria, also, there is a variety of the Gentle Falcon, which the inhabitants call Shaheen, and which is of so fierce and courageous a disposition, that it will attack any bird, however large or powerful, which presents itself. "Were there not," says Dr. Russel, in his account of Aleppo, "several gentlemen now in England to bear witness to the fact, I should hardly venture to assert that, with this bird, which is about the size of a pigeon, the inhabitants sometimes take large eagles.

"This Hawk was in former times taught to seize the eagle under the pinion, and thus depriving him of the use of one wing, both birds fell to the ground together; but the present mode is to teach the Hawk to fix on the back, between the wings, which has the same effect, only that the bird tumbling down more slowly, the falconer has more time to come to his Hawk's assistance; but in either case, if he be not very expeditious, the Falcon is inevitably destroyed.

"I never saw the Shaheen fly at eagles, that sport having been disused before my time; but I have often seen him take herons and storks. The Hawk, when thrown off, flies for some time in a horizontal line, not six feet from the ground; then mounting perpendicularly, with astonishing swiftness, he seizes his prey under the wing, and both together come tumbling to the ground." 


\section{THE OSPREY, OR FISHING HAWK. \\ (Falco, or Pandion Haliætus.)}

True to the season, o'er our sea-beat shore, The sailing Osprey high is seen to soar With broad unmoving wing; and circling slow, Marks each loose straggler in the deep below; Sweeps down like lightning, plunges with a roar, And bears his struggling victim to the shore.

THIs bird is always found on the sea-shore, or near rivers or lakes, as it feeds entirely on fish. It is common in Great Britain, and also in America, where large colonies are found of it, the birds living together like rooks. "When looking out for its prey," says Dr. Richardson, "it sails with great care and elegance, in undulating and curved lines" at a considerable height above the water, till it perceives its prey, when it pounces down upon it. It seizes the fish with its claws, sometimes scarcely appearing to dip its feet in the water, and at other times plunging entirely under the surface with force sufficient to throw up a considerable spray. It emerges again, however, so speedily, as to render it evident that it does not attack fish swimming at any great depth."

The Osprey builds a large nest either on trees or rocks, and lays two or three eggs, which have a reddish tinge, and are spotted with brown at the larger end. The old birds feed the young ones even after they have left the nest, and only rear one brood in the year. 


\section{AMERICAN GOSHAWK.-(Astur atricapillus.)}

AFTER the eagles and falcons, come the Hawks, which are similar in appearance, but smaller. They, as well as some of the falcons, are famous for having been trained to use in the chase. In the feudal times hawking was the favourite amusement of kings and nobles. We have never heard of its being practised in our country, although it is still common in Persia, and sometimes, though rarely, there are hawking parties on the continent of Europe.

The American Goshawk is twenty-one inches long; extent of wings thirty-seven inches. Its colour is dark ash, tinged with brown. Our species is related to a European one, which extends over the northern countries of the Old World. It is rare, migrating to the south in winter.

\section{ILLUSTRATIVE ANECDOTES.}

In Mr. Nuttall's Ornithology we find the following interesting particulars concerning this bird:

On the 26th of October, 1830, I received one of these birds from the proprietor of Fresh Pond Hotel, in the moult, having the stomach crammed with moles and mice, and it was shot in the act of devouring a pigeon.

The Goshawk was held in considerable esteem for falconry, and, according to Bell, was employed for this amusement by the emperor of China, who moved sometimes to these excursions in great state, often bearing a hawk on his 
hand, to let fly at any game that might be raised; which was usually pheasants, partridges, quails, or cranes. In 1269, Marco Paulo witnessed this diversion of the emperor, which probably had existed for many ages previous. The falconers distinguished these birds of sport into two classes, namely, those of falconry properly so called, and those of hawking; and in this second and inferior class were included the Goshawk, the Sparrow-hawk, Buzzard, and Harpy. This species does not soar so high as the longer-winged Hawks, and darts upon its quarry by a side glance, not by a direct descent, like the true falcon. They were caught in nets baited with live pigeons, and reduced to obedience by the same system of privation and discipline as the falcon.

A pair of these birds were kept for a long time in a cage by Buffon; he remarks, that the female was at least a third Iarger than the male, and the wings, when closed, did not reach within six inches of the end of the tail. The male, though smaller, was much more fierce and untameable. They often fought with their claws, but seldom used the bill for any other purpose than tearing their food. If this consisted of birds, they were plucked as neatly as by the hand of the poulterer; but mice were swallowed whole, and the hair and skin, and other indigestible parts, after the manner of the genus, were discharged from the mouth rolled up in little balls. Its cry was raucous, and terminated by sharp, reiterated, piercing notes, the more disagreeable the oftener they were repeated, and the cage could never be approached with- 
out exciting violent gestures and screams. Though of different sexes, and confined to the same cage, they contracted no friendship for each other which might soothe their imprisonment, and finally, to end the dismal picture, the female, in a fit of indiscriminate rage and violence, murdered her mate in the silence of the night, when all the other feathered race were wrapped in repose. Indeed their dispositions are so furious, that a Goshawk, left with any other falcons, soon effects the destruction of the whole. Their ordinary food is young rabbits, squirrels, mice, moles, young geese, pigeons, and small birds, and, with a cannibal appetite, they sometimes even prey upon the young of their own species. They construct their nests in the highest trees, and lay from two to four eggs of a bluish-white, marked with lines and spots of brown. The egg of our bird, according to Audubon, is without spots.

\section{THE HAWK OWL.-(Strix funerea.)}

THIs remarkable species, says Mr. Nuttall, forming a connecting link with the preceding genus of the Hawks, is nearly confined to the arctic wilds of both continents, being frequent in-Siberia and the fur countries from Hudson's Bay to the Pacific. A few stragglers, now and then, at distant intervals, and in the depths of winter, penetrate on the 


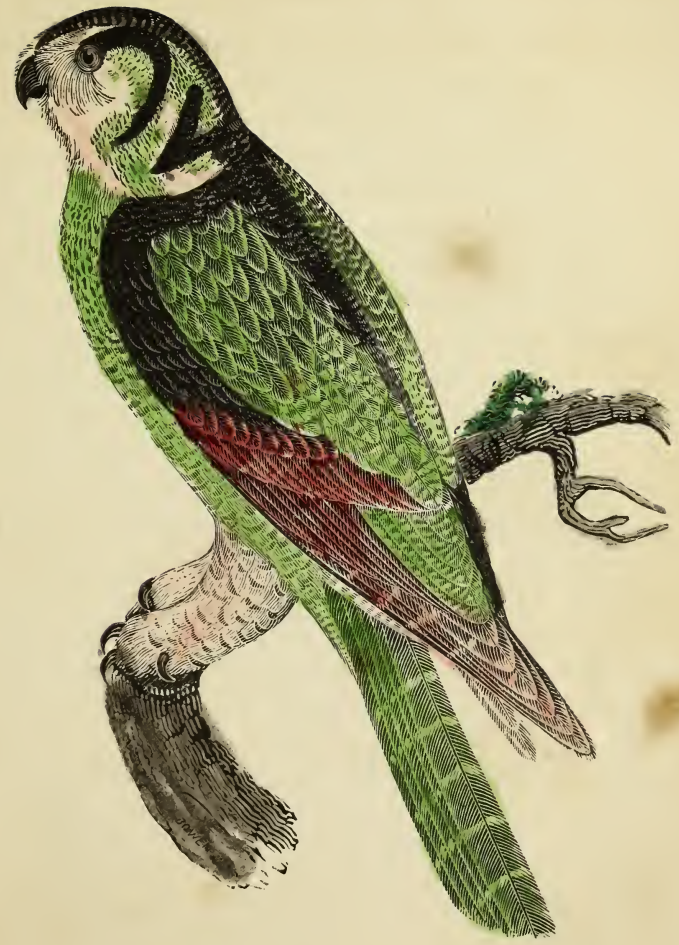



one side into the northern parts of the United States; and, on the other, they occasionally appear in Germany, and more rarely in France. At Hudson's Bay they are observed by day flying high, and preying on the white grouse and other birds, sometimes even attending the hunter like a falcon, and boldly taking up the wounded game as it flutters on the ground. They are also said to feed on mice and insects, and (according to Meyer) they nest upon trees, laying two white eggs. They are said to be constant attendants on the ptarmigans in their spring migrations towards the north; and are observed to hover round the camp-fires of the natives, in quest probably of any offal or rejected game.

\section{GREAT HORNED OWL.-(Bubo Virginiana.)}

THIs noted and formidable $\mathrm{Owl}$ is found in almost every quarter of the United States. His favourite residence, however, is in the dark solitudes of deep swamps, covered with a growth of gigantic timber; and here, as soon as evening draws on, and mankind retire to rest, he sends forth such sounds as seem scarcely to belong to this world, startling the solitary pilgrim as he slumbers by his forest fire,

\section{Making night hideous.}

Along the mountainous shores of the Ohio, and amidst the 
deep forests of Indiana, alone, and reposing in the woods, this ghostly watchman has frequently warned the traveller of the approach of morning, and amused him with his singular exclamations, sometimes sweeping down and around the fire, uttering a loud and sudden Waugh 0 ! Waugh 0 ! sufficient to have alarmed a whole garrison. He has other nocturnal solos, no less thelodious, one of which very strikingly resembles the half-suppressed screams of a person suffocating, or throttled, and cannot fail of being exceedingly entertaining to a lonely, benighted traveller, in the midst of an Indian wilderness!

This species inhabits the country round Hudson's Bay; and according to Pennant, who considers it a mere variety of the Eagle Owl (Strix bubo) of Europe, is found in Kamtschatka; extends even to the arctic regions, where it is often found white; and occurs as low as Astrakan. It has also been seen white in the United States; but this has doubtless been owing to disease or natural defect, and not to climate.

It preys on young rabbits, squirrels, rats, mice, partridges, and small birds of various kinds.

\section{ILLUSTRATIVE ANECDOTES.}

The Great Horned $\mathrm{Owl}$ is famous for his depredations on the poultry-yard. A very large one, who had his wing broken by a shot while on a foraging expedition of this 
kind about a farm-house, was captured and kept for several days, and at length disappeared, no one knew whither.

Almost every day after this, hens and chickens also disappeared, one by one, in an unaccountable manner, till in eight or ten days very few were left remaining. The fox, the minx, and weasel, were alternately the reputed authors of this mischief, until one morning, the old ady herself, rising before day to bake, in passing towards the oven, surprised her late prisoner, the $\mathrm{Owl}$, regaling himself on the body of a newly killed hen! The thief instantly made for his hole under the house, from whence the enraged matron soon dislodged him with the brush-handle, and without mercy despatched him. In this snug retreat were found the greater part of the feathers, and many large fragments, of her whole family of chickens.

There is something in the character of the $O \mathrm{wl}$ so recluse, solitary, and mysterious, something so discordant in the tones of its voice, heard only amid the silence and gloom of night, and in the most lonely and sequestered situations, as to have strongly impressed the minds of mankind in general with sensations of awe and abhorrence of the whole tribe. The poets have indulged freely in this general prejudice; and in their descriptions and delineations of midnight storms, and gloomy scenes of nature, the Owl is generally introduced to heighten the horror of the picture.

-Ignorance and superstition, in all ages, and in all countries, 
listen to the voiee of the $\mathrm{O} w \mathrm{l}$, and even contemplate its physiognomy with feelings of disgust, and a kind of fearful awe. The priests, or conjurers, among some of our Indian nations, have taken advantage of the reverential horror for this bird, and have adopted the Great Horned Owl, the subject of the present account, as the symbol or emblem of their office.

"Among the Creeks," says Mr. Bartram, in his Travels, p. 504, "the junior priests, or students, constantly wear a white mantle, and have a Great Owl skin cased and stuffed very ingeniously, so well executed as almost to appear like the living bird, having large, sparkling glass beads or buttons, fixed in the head for eyes. This insignia of wisdom and divination they wear sometimes as a crest on the top of the head; at other times the image sits on the arm, or is borne on the hand. These bachelors are also distin. guished from the other people by their taciturnity, grave and solemn countenance, dignified step, and singing to themselves songs or hymns in a low, sweet voice, as they stroll about the town."

Nothing is a more effectual cure for superstition than a knowledge of the general laws and productions of nature; nor more forcibly leads our reflections to the first, great, self-existent CAUSE of all, to whom our reverential awe is then humbly devoted, and not to any of his dependent creatures. With all the gloomy habits and ungracious tones of the $\mathrm{Owl}$, there is nothing in this bird supernatural 
or mysterious, or more than that of a simple bird of prey, formed for feeding by night, like many other animals, and of reposing by day. The harshness of its voice, occasioned by the width and capacity of its throat, may be intended by Heaven as an alarm and warning to the birds and animals on which it preys, to secure themselves from danger. The voices of all carnivorous birds and animals are also observed to be harsh and hideous, probably for this very purpose.

The Great Horned Owl is not migratory, but remains with us the whole year. During the day he slumbers in the thick evergreens of deep swamps, or seeks shelter in large hollow trees. He is very rarely seen abroad by day, and never but when disturbed. In the month of May they usually begin to build. The nest is generally placed in the fork of a tall tree, and is constructed of sticks piled in considerable quantities, lined with dry leaves and a few feathers. Sometimes they choose a hollow tree; and, in that case, carry in but few materials. The female lays four eggs, nearly as large as those of a hen; almost globular, and of a pure white. In one of these nests, after the young had flown, were found the heads and bones of two chickens, the legs and head of the golden-winged woodpecker, and part of the wings and feathers of several other birds. It is generally conjectured that they hatch but once in the season.

According to all authorities, Owls have been regarded as objects of superstition; and this has sometimes been taken 


\section{THE GREAT HORNE D OWL.}

advantage of by the well informed, for purposes far from what ought to be the duty of a better education to inculcate. None are more accessible to such superstitions than the primitive natives of Ireland, and the north of Scotland. Dr. Richardson thus relates an instance, which came to his own knowledge, of the consequences arising from a visit of this nocturnal wanderer :

"A party of Scottish Highlanders, in the service of the Hudson's Bay Company, happened, in a winter journey, to encamp after nightfall in a dense clump of trees, whose dark tops and lofty stems, the growth of more than one century, gave a solemnity to the scene that strongly tended to excite the superstitious feelings of the Highlanders. The effect was heightened by the discovery of a tomb, which, with a natural taste often exhibited by the Indians, had been placed in this secluded spot. Our travellers, having finished their supper, were trimming their fire preparatory to retiring to rest, when the slow and dismal notes of the Horned Owl fell on the ear with a startling nearness. None of them being acquainted with the sound, they at once concluded, that so unearthly a voice must be the moaning of the spirit of the departed, whose repose they supposed they had disturbed, by inadvertently making a fire of some of the wood of which his tomb had been constructed. They passed a tedious night of fear, and, with the first dawn of day, hastily quitted the ill-omened spot." 


\section{THE SWALLOW. (Hirundo rustica.)}

THe second order of birds, Insessores, or Perching Birds, includes an immense number of genera and species. We shall notice the more interesting, without troubling our readers with their numerous subdivisions. We commence with the Swallow, as one of the most common.

Swallows are easily distinguished from all other birds, not only by their general structure, but by their twittering: note and mode of flying, or rather darting from place to place.

They appear in the temperate regions in April, and building in some out-house, or in part of a human dwelling, they lay their eggs and hatch their young. About August they disappear, and do not return till the following spring. Swallows kept in a cage moult about Christmas, and seldom live till spring.

There are several species of the Swallow: the general characters, a small beak, but large wide mouth, for the purpose of swallowing flying insects, their natural food; and long forked tail and extensive wings, to enable them to pursue their prey, belong to all of them. The common house Swallow builds under the eaves of houses, or in chimneys, near their top: the Martin also builds under eaves, and very commonly against the upper corner or side of our very windows, and seems not afraid at the sight of man, yet it cannot be tamed, or even kept long in a cage. 
The nature of the Swallow's nest is worthy our serious observation : how the mud is extracted from the sea-shores, rivers, or other watery places; how masoned and formed into a solid building, strong enough to support a whole family, and to face the "pelting storm," are wonders which ought to raise our mind to Him who bestowed that instinct upon them.

\section{ILLUSTRATIVE ANECDOTE.}

It is related that a pair of Swallows built their nest for two successive years on the handle of a pair of garden shears, that were stuck up against the boards in an outhouse; and, therefore, must have had their nest spoiled whenever the implement was wanted. And what is still more strange, a bird of the same species built its nest on the wings and body of an owl that happened to hang dead and dry from the rafters of a barn, and so loose as to be moved by every gust of wind. This owl, with the nest on its wings, and with eggs in the nest, was taken to the museum of Sir Ashton Lever as a curiosity. That gentleman, struck with the singularity of the sight, furnished the person who brought it with a large shell, desiring him to fix it just where the owl had hung. The man did so; and in the following year a pair of Swallows, probably the same, built their nest in the shell, and laid eggs. 


\section{THE CHIMNEY SWALLOW.}

The Chimney Swallow is on the head, neck, back, and rump, of a shining black colour, with purple gloss and sometimes with a blue shade; the throat and neck are of the same colour; the breast and belly are white, with a dash of red. The tail is forked, and consists of twelve feathers. The wings are of the same colour with the back. Swallows feed upon flies, worms, and insects; and generally hunt their prey on the wing.

\section{THE BANK SWALLOW.}

THIs appears (says Mr. Wilson) to be the most sociable with its kind, and the least intimate with man, of all our Swallows; living together in large communities of sometimes three or four hundred. On the high sandy bank of a river, quarry, or gravel-pit, at a foot or two from the surface, they commonly scratch out holes for their nests, running them in a horizontal direction to the depth of two and sometimes three feet. Several of these holes are often within a few inches of each other, and extend in various strata along the front of the precipice, sometimes for eighty or one hundred yards. At the extremity of this hole, a 
little fine, dry grass, with a few large, downy feathers, form the bed on which their eggs, generally five in number, and pure white, are deposited.

The young are hatched late in May; and here I have taken notice of the common crow, in parties of four or five, watching at the entrance of these holes, to seize the first straggling young that should make its appearance. From the clouds of Swallows that usually play round these breeding-places, they remind one at a distance of a swarm of bees.

The Bank Swallow arrives here earlier than either of the preceding; begins to build in April, and has commonly two broods in the season. Their voice is a low mutter. They are particularly fond of the shores of rivers, and, in several places along the Ohio, they congregate in immense multitudes.

\section{BALTIMORE ORIOLE. (Oriolus Baltimore.)}

THIs is a bird of passage, arriving in Pennsylvania, from the south, about the beginning of May, and departing towards the latter end of August, or beginning of September. During migration, the flight of the Baltimore is high above all the trees, and is straight and continuous; it is mostly performed during the day, as they are usually observed alighting, always singly, about the setting of the sun, utter- 
ing a note or two, and darting into the lower branches to feed, and afterwards to rest.

From the singularity of its colours, the construction of its nest, and its preferring the apple-trees, weeping willows, walnut and tulip-trees, adjoining the farm-house, to build on, it is generally known, and, as usual, honoured with a variety of names, such as Hang-nest, Hanging-Bird, Golden Robin, Fire-Bird (from the bright orange seen through the green leaves, resembling a flash of fire), \&c., but more generally the Baltimore Bird, so named, as Catesby informs us, from its colours, which are black and orange, being those of the arms or livery of Lord Baltimore, formerly proprietary of Maryland.

Their principal food consists of caterpillars, beetles, and bugs, particularly one of a brilliant glossy green, fragments of which are almost always found in their stomach, and sometimes these only.

The Baltimore inhabits North America from Canada to Mexico, and is even found as far south as Brazil.

\section{ILLUSTRATIVE ANECDOTES.}

There is nothing more remarkable (says Mr. Nuttall) in the whole instinct of our Golden Robin, than the ingenuity displayed in the fabrication of its nest, which is, in fact, a pendulous cylindric pouch of five to seven inches in depth, usually suspended from near the extremities of the high, 
drooping branches of trees (such as the elm, the pear, or apple-tree, wild cherry, weeping willow, tulip-tree, or buttonwood). It is begun by firmly fastening natural strings of the flax of the silk weed, or swamp-hollyhock, or stout artificial threads, round two or more forked twigs, corresponding to the intended width and depth of the nest. With the same materials, willow down, or any accidental ravellings, strings, thread, sewing-silk, tow, or wool, that may be lying near the neighbouring houses, or round the grafts of trees, they interweave and fabricate a sort of coarse cloth into the form intended; towards the bottom of which they place the real nest, made chiefly of lint, wiry grass, horse and cow hair, sometimes, in defect of hair, lining the interior with a mixture of slender strips of smooth vine bark, and rarely with a few feathers, the whole being of a considerable thickness, and more or less attached to the external pouch. Over the top, the leaves, as they grow out, form a verdant and agreeable canopy, defending the young from the sun and rain. There is sometimes a considerable difference in the manufacture of these nests, as well as in the materials which enter into their composition. Both sexes seem to be equally adepts at this sort of labour, and I have seen the female alone perform the whole without any assistance, and the male also complete this laborious task nearly without the aid of his consort; who, however, in general, is the principal worker. I have observed a nest made almost wholly of tow, which was laid out for the convenience of a 


\section{THE BALTIMORE ORIOLE.}

male bird; who, with this aid, completed his labour in a very short time, and frequently sung in a very ludicrous manner, while his mouth was loaded with a mass larger than his head. So eager are they to obtain fibrous materials, that they will readily tug at, and even untie hard knots made of tow. In Audubon's magnificent plates, a nest is represented as formed outwardly of the long-moss; where this abounds, of course, the labour of obtaining materials must be greatly abridged. The author likewise remarks, that the whole fabric consists almost entirely of this material, loosely interwoven, without any warm lining, a labour which our ingenious artist seems aware would be superfluous in the warm forests of the lower Mississippi. A female, which I observed attentively, carried off to her nest a piece of lamp-wick ten or twelve feet long. This long string, and many other shorter ones, were left hanging out for about a week before both the ends were wattled into the sides of the nest. Some other little birds, making use of similar materials, at times twitched these flowing ends, and generally brought out the busy Baltimore from her occupation in great anger.

The haste and eagerness of one of these airy architects, which I accidentally observed on the banks of the Susquehanna, appeared likely to prove fatal to a busy female, who, in weaving, got a loop round her neck, and no sooner was she disengaged from this snare, than it was slipped round her feet, and thus held her fast beyond the power of escape! The male came frequently to the scene, now changed from 
that of joy and hope into despair, but seemed wholly incapable of comprehending or relieving the distress of his mate. In a second instance, I have been told that a female has been observed dead in the like predicament.

\section{THE ROBIN. (Turdus migratorius.)}

Thrs well-known bird, being familiar to almost everybody, will require but a short description. It measures nine inches and a half in length; the bill is strong, an inch long, and of a full yellow, though sometimes black, or dusky near the tip of the upper mandible; the head, back of the neck, and tail, is black; the back and rump, an ash colour; the wings are black, edged with light ash; the inner tips of the two exterior tail-feathers are white; three small spots of white border the eye; the throat and upper part of the breast is black, the former streaked with white; the whole of the rest of the breast, down as far as the thighs, is of a dark orange; belly and vent, white, slightly waved with dusky ash; legs, dark brown; claws, black and strong. The colours of the female are more of the light ash, less deepened with black; and the orange on the breast is much paler, and more broadly skirted with white.

The name of this bird bespeaks him a bird of passage, as 


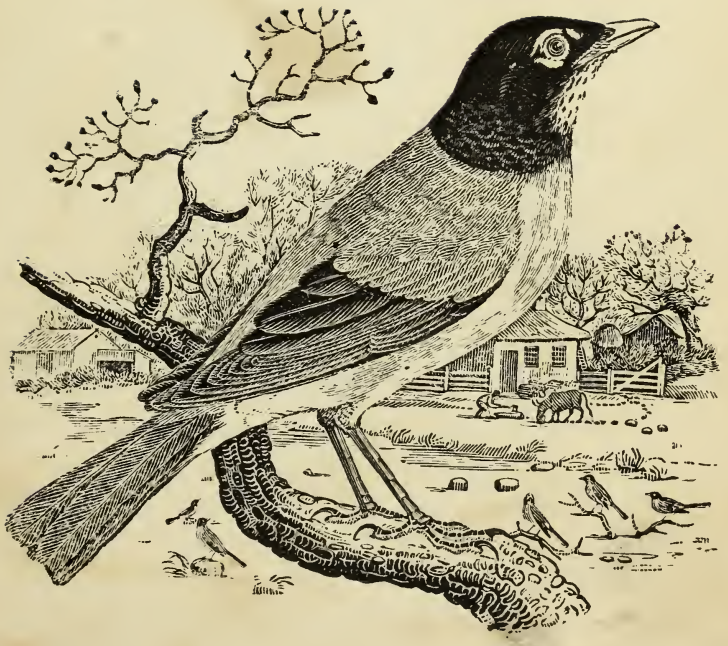



are all the different species of thrushes we have; but the one we are now describing, being more unsettled, and continually roving about from one region to another, during fall and winter, seems particularly entitled to the appellation. Scarce a winter passes but innumerable thousands of them are seen in the lower parts of the whole Atlantic states, from New Hampshire to Carolina, particularly in the neighbourhood of our towns; and, from the circumstance of their leaving, during that season, the country to the north-west of the great range of the Alleghany, from Maryland northward, it would appear that they not only migrate from north to south, but from west to east, to avoid the deep snows that generally prevail on these high regions for at least four months in the year.

The Robin builds a large nest, often on an apple-tree, plasters it in the inside with mud, and lines it with hay or fine grass. The female lays five eggs, of a beautiful seagreen. Their principal food is berries, worms, and caterpillars. Of the first he prefers those of the sour gum. So fond are they of gum-berries, that, wherever there is one of these trees covered with fruit, and flocks of Robins in the neighbourhood, the sportsman need only take his stand near it, load, take aim, and fire; one flock succeeding another, with little interruption, almost the whole day: by this method, prodigious slaughter has been made among them with little fatigue. When berries fail, they disperse themselves over the fields, and along the 
fences, in search of worms and other insects. Sometimes they will disappear for a week or two, and return again in greater numbers than before; at which time the cities pour out their sportsmen by scores, and the markets are plentifully supplied with them at a cheap rate.

\section{ILLUSTRATIVE ANECDOTES.}

In January, 1807, two young men, in one excursion, shot thirty dozen Robins. . In the midst of such devastation, which continued many weeks, and, by accounts, extended from Massachusetts to Maryland, some humane person took advantage of a circumstance common to these birds in winter, to stop the general slaughter. The fruit called poke-berries is a favourite repast with the Robin, after they are mellowed by the frost. The juice of the berries is of a beautiful crimson, and they are eaten in such quantities by these birds, that their whole stomachs are strongly tinged with the same red colour.

A paragraph appeared in the public news papers, intimating, that, from the great quantities of these berries which the Robins had fed on, they had become unwholesome, and even dangerous food; and that several persons had suffered by eating of them. The strange appearance of the bowels of the birds seemed to corroborate this account. The demand for, and use of them, ceased almost instantly; 
and motives of self-preservation produced at once what all the pleadings of humanity could not effect.

When fat, they are in considerable esteem for the table, and probably not inferior to the Turdi of the ancients, which they bestowed so much pains on in feeding and fattening. The young birds are frequently and easily raised, bear the confinement of the cage, feed on bread, fruits, \&c., sing well, readily learn to imitate parts of tunes, and are very pleasant and cheerful domestics. In these I have always observed (says Wilson) that the orange on the breast is of a much deeper tint, often a dark mahogany or chestnut colour owing, no doubt, to their food and confinement.

\section{THE NIGHTINGALE. (Sylvia Tuscinia.)}

Alc the birds we have hitherto described are American. We now come to a bird of the Old World, celebrated by the poets of all ages. It is thus described by an English writer :-

The Nightingale has little to boast, if we consider its plumage, which is of a pale tawny colour on the head and back, dashed with a little shade of olive; the breast and upper part of the belly incline to a grayish tint, and the lower part of the belly is almost white; the exterior web 
66 T H E N I GH T ING A L E.

of the quill-feathers is of a reddish brown; the tail of a dull red; the legs and feet ash-coloured; the irides hazel; and the eyes large, bright, and staring. It is hardly possible to give an idea of the extraordinary power which this small bird possesses in its throat, as to extension of sound, sweetness of tone, and versatility of notes. Its song is composed of several musical passages, each of which does not continue more than the third part of a minute; but they are so varied, the passing from one tone to another is so fanciful and so rapid, and the melody so sweet and so mellow, that the most consummate musician is pleasingly led to a deep sense of admiration at hearing it. Sometimes joyful and merry, it runs down the diapason with the velocity of lightning, touching the treble and the bass nearly at the same instant; at other times, mournful and plaintive, the unfortunate Philomela draws heavily her lengthened notes, and breathes a delightful melancholy around. These have the appearance of sorrowful sighs ; the other modulations resemble the laughter of the happy. Solitary on the twig of a small tree, and cautiously at a certain distance from the nest, where the pledges of his love are treasured under the fostering breast of his mate, the male fills constantly the silent woods with his harmonious strains; and during the whole night entertains and repays his female for the irksome duties of incubation. For the Nightingale not only sings at intervals during the day, but he waits till the blackbird and the thrush have uttered their evening call, 
eren till the stock and ring doves have, by their soft murmurings, lulled each other to rest, and then he pours forth his full tide of melody.

Listening Philomela deigns

To let them joy, and purposes, in thought

Elate, to make her night excel their day.

Thomson.

It is a great subject of astonishment that so small a bird should be endowed with such potent lungs. If the evening is calm, it is supposed that its song may be heard above half a mile. This bird, the ornament and charm of the spring and early summer evenings, as it arrives in April, and continues singing till June, disappears on a sudden about September or October, when it leaves England to pass the winter in the North of Africa and Syria. Its visits to England are limited to certain counties, mostly in the south and east; as, though it is plentiful in the neighbourhood of London, and along the south coast in Sussex, Hampshire, and Dorsetshire: it is not found in either Cornwall or Wales. As soon as the young are hatched, the song of the male bird ceases, and he only utters a harsh croak, by way of giving alarm when any one approaches the nest. Nightingales are sometimes reared up, and doomed to the prison of a cage; in this state they sing ten months in the year, though in their wild life they sing only as many weeks. Bingley says that a cajed Nightingale sings much more sweetly than those which we hear abroad in the spring. 
58 THE RED-WINGED BLACKBIRD.

THE RED-WINGED BLACKBIRD, OR TROOPIAL. (Sturnus predatorius.)

THIs bird is common in all parts of North America. He is nine inches in length and fourteen in extent. The general colour is glossy black, with a very splendid scarlet marking, like a broad epaulette, on his shoulders. His habits will be learned from the following

\section{ILLUSTRATIVE ANECDOTES.}

Mr. Wilson calls this bird the Red-winged Starling, and gives us from his own observation the following curious particulars of his winter habits :-

The Red-winged Starlings, though generally migratory in the states north of Maryland, are found during winter in immense flocks, sometimes associated with the purple grakles, and often by themselves, along the whole lower parts of Virginia, both Carolinas, Georgia, and Louisiana, particularly near the sea-coast, and in the vicinity of large rice and corn-fields.

In the months of January and February, while passing through the former of these countries, I was frequently entertained with the aerial evolutions of these great bodies of Starlings. Sometimes they appeared driving about like an enormous black cloud carried before the wind, varying its shape every moment; sometimes suddenly rising from 


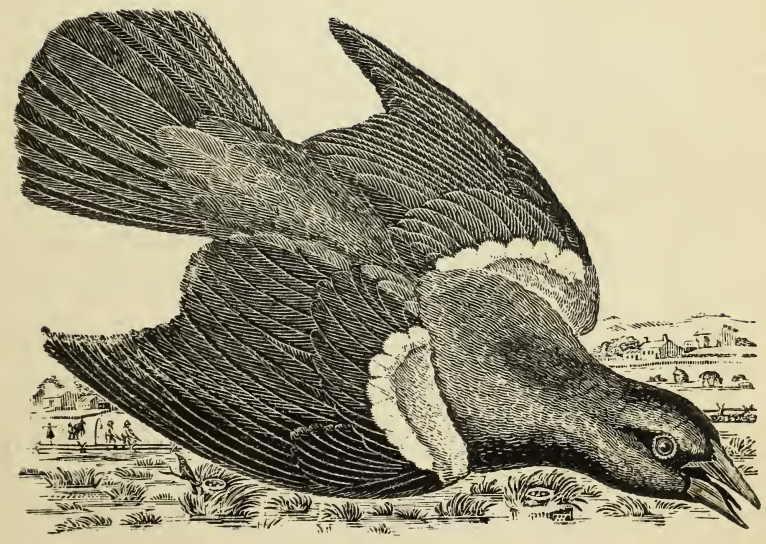



the fields around me with a noise like thunder; while the glittering of innumerable wings of the brightest vermillion amid the black cloud they formed, produced on these occasions a very striking and splendid effect. Then, desccnding like a torrent, and covering the branches of some detached grove, or clump of trees, the whole congregated multitude commenced one general concert or chorus, that I have plainly distinguished at the distance of more than two miles, and, when listened to at the intermediate space of about a quarter of a mile, with a slight breeze of wind to swell and soften the flow of its cadences, was to me grand, and even sublime.

The whole season of winter, that, with most birds, is passed in struggling to sustain life in silent melancholy, is, with the Red-wings, one continued carnival. The profuse gleanings of the old rice, corn, and buckwheat-fields, supply them with abundant food, at once ready and nutritious; and the intermediate time is spent either in aerial manouvres, or in grand vocal performances, as if solicitous to supply the absence of all the tuneful summer tribes, and to cheer the dejected face of nature with their whole combined powers of harmony.

From the same excellent authority we gather the following particulars of the Troopial's ravages in the corn-fields :-

Before the beginning of September, the flocks have become numerous and formidable; and the young ears of maize, or Indian corn, being then in their soft, succulent, milky, state, present a temptation that caunot be resisted. Rein- 
60 THE RED-WINGED BLACK BIRD.

forced by numerous and daily flocks from all parts of the interior, they pour down on the low countries in prodigious multitudes. Here they are seen, like vast clouds, wheeling and driving over the meadows and devoted corn-fields, darkening the air with their numbers. Then commences the work of destruction on the corn, the husks of which, though composed of numerous envelopments of closelywrapped leaves, are soon completely or partially torn off; while from all quarters myriads continue to pour down like a tempest, blackening half an acre at a time; and, if not disturbed, repeat their depredations, till little remains but the cob and the shrivelled skins of the grain; what little is left of the tender ear, being exposed to the rains and weather, is generally much injured.

All the attacks and havoc made at this time among them with the gun, and by the hawks, - several species of which are their constant attendants, - has little effect on the remainder. When the hawks make a sweep among them, they suddenly open on all sides, but rarely in time to disappoint them of their victims; and, though repeatedly fired at, with mortal effect, they only remove from one field to an adjoining one, or to another quarter of the same enclosure. From dawn to nearly sunset, this open and daring devastation is carried on, under the eye of the proprietor; and a farmer, who has any considerable extent of corn, would require half-a-dozen men at least, with guns, to guard it; and even then, all their vigilance and activity would not 
prevent a good tithe of it from becoming the prey of the Blackbirds. The Indians, who usually plant their corn in one general field, keep the whole young boys of the village all day patrolling round and among it; and each being furnished with bow and arrows, with which they are very expert, they generally contrive to destroy great numbers of them.

It must, however, be observed, that this scene of pillage is principally carried on in the low countries, not far from the sea-coast, or near the extensive flats that border our large rivers; and is also chiefly confined to the months of August and September. After this period, the corn having acquired its hard, shelly coat, and the seeds of the reeds or wild oats, with a profusion of other plants, that abound along the river shores, being now ripe, and in great abundance, they present a new and more extensive field for these marauding multitudes. The reeds also supply them with convenient roosting places, being often in almost unapproachable morasses; and thither they repair every evening, from all quarters of the country.

In some places, however, when the reeds become dry, advantage is taken of this circumstance, to destroy these birds, by a party secretly approaching the place, under cover of a dark night, setting fire to the reeds in several places at once, which being soon enveloped in one general flame, the uproar among the Blackbirds becomes universal; and, by the light of the conflagration, they are shot down 
in vast numbers, while hovering and screaming over the place. Sometimes straw is used for the same purpose, being previously strewed near the reeds and alder bushes, where they are known to roost, which being instantly set on fire, the consternation and havoc are prodigious; and the party return by day to pick up the slaughtered game. About the first of November, they begin to move off towards the south; though, near the sea-coast, in the states of New Jersey and Delaware they continue long after that period.

\section{THE SKYLARK. (Alauda arvensis.)}

ONE of the most celebrated of all the English birds is the Skylark. His music being associated with the rural employments and pleasures of that enlightened and refined nation, has occasicned his being described in rapturous terms by their poets and novelists.

The Skylark is generally distinguished from most other birds, by the long spur on his back toe, the earthy colour of his feathers, and by singing as he mounts up in the air. The common Skylark is not much bigger than the housesparrow. These birds generally make their nest in meadows among the high grass, and the tint of their plumage resembles so much that of the ground, that the body of the bird is hardly distinguishable as it hops along. 
The daisied lea he loves, where tufts of grass

Luxuriant crown the ridge: there, with his mate,

He founds their lonely house, of withered herbs,

And coarsest spear-grass; next the inner work,

With finer, and still finer fibres lays,

Rounding it curious with his speckled breast.

Grahame.

Larks breed thrice a year, in May, July, and August, rearing their young in a short space of time.

\section{ILLUSTRATIVE ANECDOTES.}

The instinctive warmth of attachment which the female Skylark bears towards her own species, even when not her nestling, is remarkable. "In the month of May," says Buffon, "a young hen bird was brought to me, which was not able to feed without assistance. I caused her to be reared; and she was hardly fledged, when I received from another place, a nest of three or four unfledged larks. She took a strong liking to these new comers, which were but little younger than herself; she tended them night and day, cherished them beneath her wings, and fed them with her bill. Nothing could interrupt her tender offices. If the young ones were torn from her she flew to them as soon as they were liberated, and would not think of effecting her own escape, which she might have done a hundred times. Her affection grew upon her; she neglected food and drink; she at length required the same support as her adopted offspring, and expired at last, consumed with maternal soli- 
citude. None of the young ones long survived her. They died one after another; so essential wcre her cares, which were equally tender and judicious."

The Lark mounts almost perpendicularly, and by successive springs, into the air; where it hovers at a vast height. Its descent is in an oblique direction, unless threatened by some ravenous bird of prey, or attracted by its mate; when it drops to the ground like a stone. On its first leaving the earth, its notes are feeble and interrupted; but, as it rises, these gradually swell to their full tone. As the Lark's flight is always at sun-rise, there is something in the scenery that renders the music of the lark peculiarly delightful: the opening morning, and the landscape just gilded by the rays of the returning sun, and the beauty of the surrounding objects, all contribute to heighten our relish for its pleasing song.

\section{TIIE CARDINAL BIRD. (Cardinalis Virginianus.)}

THIs is one of our most common cage birds; and is very generally known, not only in North America, but even in Europe, numbers of them having been carried over both to France and England, in which last country they are usually called Virginia Nightingales. To this name, Dr. Latham observes, "they are fully entitled," from the clearness and 


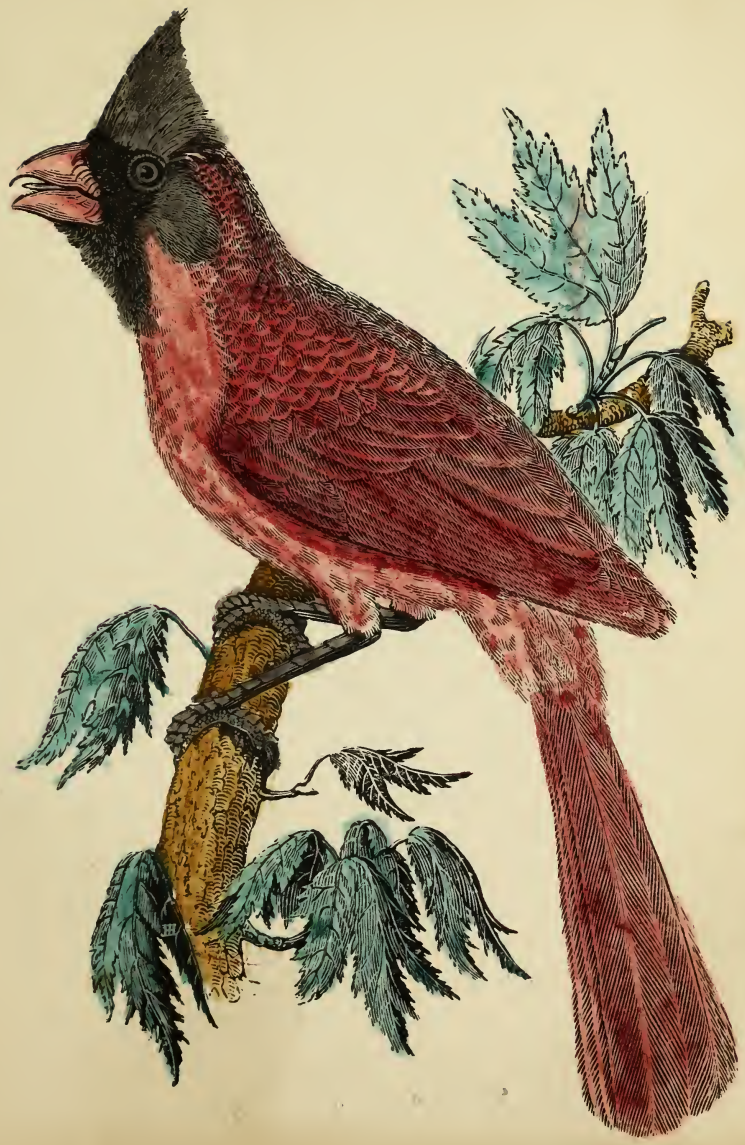



variety of their notes, which, both in a wild and domestic state, are very various and musical : many of them resemble the high notes of a fife, and are nearly as loud. They are in song from March to September, beginning at the first appearance of dawn, and repeating a favourite stanza, or passage, twenty or thirty times successively; sometimes, with little intermission, for a whole morning together, which, like a good story too often repeated, becomes at length tiresome and insipid. But the sprightly figure and gaudy plumage of the Red-Bird, his vivacity, strength of voice, and actual variety of note, and the little expense with which he is kept, will always make him a favourite.

The Cardinal Bird is eight inches long, and eleven in extent. The whole upper parts are a dusky red, except the sides of the neck and the head, which, as well as all the lower parts, are bright vermilion, and chin and front black. The head is ornamented with a pointed crest, which may be raised or lowered at pleasure. The beak is red, thick and strong. The female is smaller, but nearly as brilliant in plumage, and sings nearly as well as the male.

\section{ILLUSTRATIVE ANECDOTES.}

The opinion which so generally prevails in England (says Wilson) that the music of the groves and woods of America is far inferior to that of Europe, I, who have a thousand times listened to both, cannot admit to be correct. We cannot with fairness draw a comparison between tho depth 
66 THE CAR DINAL BIRD

of the forest in America, and the cultivated fields of England; because it is a well-known fact, that singing birds seldom frequent the former in any country. But let the latter places be compared with the like situations in the United States, and the superiority of song, I am fully persuaded, would justly belong to the western continent. The few of our song birds that have visited Europe extort admiration from the best judges. "The notes of the Cardinal Grosbeak," says Latham, "are almost equal to those of the nightingale." Yet these notes, clear and excellent as they are, are far inferior to those of the wood thrush, and even to those of the brown thrush, or thrasher. Our inimitable mocking bird is also acknowledged, by themselves, to be fully equal to the song of the nightingale, "in its whole compass." Yet these are not one tenth of the number of our singing birds. Could these people be transported to the borders of our woods and settlements, in the month of May, about half an hour before sunrise, such a ravishing concert would greet their ear as they have no conception of.

The males of the Cardinal Grosbeak, when confined together in a cage, fight violently. On placing a lookingglass before the cage, the gesticulations of the tenant are truly laughable: yet with this he soon becomes so well acquainted, that, in a short time, he takes no notice whatever of it; a pretty good proof that he has discovered the true cause of the appearance to proceed from himself. They 
are hardy birds, easily kept, sing six or eight months in the year, and are most lively in wet weather. They are generally known by the names; Red-Bird, Virginia RedBird, Virginia Nightingale, and Crested Red-Bird, to distinguish them from another beautiful species, the Scarlet Tanager.

I do not know that any successful attempts have been made to induce these birds to pair and breed in confinement; but I have no doubt of its practicability, by proper management. Some months ago, I placed a young, unfledged cow-bird, whose mother, like the cuckoo of Europe, abandons her eggs and progeny to the mercy and management of other smaller birds, in the same cage with a Red-Bird, which fed and reared it with great tenderness. They both continue to inhabit the same cage, and I have hopes that the Red-Bird will finish his pupil's education by teaching him his song.

\section{THE MOCKING BIRD. (Mimus Polyglottus.)}

THIs splendid songster is not remarkable for the beauty of his plumage. His general colour is ashy, whitish beneath, tips of the wing-coverts and lateral tail-feathers white; general form slender and graceful; length nine inches and a half, extent thirteen inches. He is found in various parts 
68

T II E M O C K ING B I R D.

of America, from the Middle States to Brazil. His food consists of insects, berries, and worms.

\section{ILLUSTRATIVE ANECDOTES.}

Mr. Wilson, an enthusiastic admirer of the Mocking Bird, thus describes his song:

The Mocking Bird loses little of the power and energy of his song by confinement. In his domesticated state, when he commences his career of song, it is impossible to stand by uninterested. He whistles for the dog,-Cæsar starts up, wags his tail, and runs to meet his master. He squeaks out like a hurt chicken,-and the hen hurries about with hanging wings, and bristled feathers, clucking to protect its injured brood. The barking of the dog, the mewing of the cat, the creaking of a passing wheelbarrow, follow with great truth and rapidity. He repeats the tune taught him by his master, though of considerable length, fully and faithfully. He runs over the quiverings of the canary, and the clear whistlings of the Virginia nightingale, or red-bird, with such superior execution and effect, that the mortified songsters feel their own inferiority, and become altogether silent; while he seems to triumph in their defeat by redoubling his exertions.

Were it not to seem invidious in the eyes of foreigners, I might, in this place, make a comparative statement between the powers of the Mocking Bird, and the only bird, I believe, in the world, worthy of being compared with him,-the 
European nightingale. This, however, I am unable to do from my own observation, having never myself heard the song of the latter; and, even if I had, perhaps something might be laid to the score of partiality, which, as a faithful biographer, I am anxious to avoid. I shall, therefore, present the reader with the opinion of a distinguished English naturalist and curious observer, on this subject, the Honourable Daines Barrington, who, at the time he made the communication, was vice-president of the Royal Society, to which it was addressed.

"It may not be improper here," says this gentleman, "to consider whether the nightingale may not have a very formidable competitor in the American Mocking Bird, though almost all travellers agree, that the concert in the European woods is superior to that of the other parts of the globe." "I have happened, however, to hear the American Mocking Bird, in great perfection, at Messrs. Vogels and Scotts, in Love Lane, Eastcheap. This bird is believed to be still living, and hath been in England these six years. During the space of a minute, he imitated the woodlark, chaffinch, blackbird, thrush, and sparrow. I was told also that he would bark like a dog; so that the bird seems to have no choice in his imitations, though his pipe comes nearest to our nightingale of any bird I have yet met with.

"With regard to the original notes, however, of this bird, we are still at a loss, as this can only be known by those who are accurately acquainted with the song of the other 
American birds. Kalm indeed informs us, that the natural song is excellent; but this traveller seems not to have been long enough in America to have distinguished what were the genuine notes: with us, mimies do not often succeed but in imitations. I have little doubt, however, but that this bird would be fully equal to the song of the nightingale in its whole compass; but then, from the attention which the Mocker pays to any other sort of disagreeable noise, these capital notes would be always debased by a bad mixture."

\section{THE CROW. (Corvus Corone.)}

Mr. WILson considers our American Crow identical with the European species. It is eighteen inches and a half long, and three feet two inches in extent; the colour shining glossy blue-black; bill and legs black. In other particulars it agrees with the European Crow.

$\mathrm{He}$ is the most generally known and least beloved of all our land birds; having (as Mr. Wilson observes) neither melody of song, nor beauty of plumage, nor excellence of flesh, nor civility of manners to recommend him; on the contrary, he is branded as a thief and a plunderer - a kind of black-coated vagabond, who hovers over the fields of the industrious, fattening on their labours, and, by his voracity, 
often blasting their expectations. Hated as he is by the farmer, watched and persecuted by almost every bearer of a gun, who all triumph in his destruction, had not Heaven bestowed on him intelligence and sagacity far beyond common, there is reason to believe that the whole tribe (in these parts at least) would long ago have ceased to exist.

It is in the month of May, and until the middle of June, that the Crow is most destructive to the corn-fields, digging up the newly planted grains of maize, pulling up by the roots those that have begun to vegetate, and thus frequently obliging the farmer to replant, or lose the benefit of the soil; and this sometimes twice, and even three times, occasioning a considerable additional expense, and inequality of harvest. No mercy is now shown him. The myriads of worms, moles, mice, caterpillars, grubs, and beetles, which he has destroyed, are altogether overlooked on these occasions. Detected in robbing the hens' nests, pulling up the corn, and killing the young chickens, he is considered as an outlaw, and sentenced to destruction. But the great difficulty is, how to put this sentence in execution. In vain the gunner skulks along the hedges and fences; his faithful sentinels, planted on some commanding point, raise the alarm, and disappoint vengeance of its object. The coast again clear, he returns once more in silence, to finish the repast he had begun. Sometimes he approaches the farm-house by stealth, in search of young chickens, which he is in the habit of snatching off, when be can elude the 
vigilance of the mother hen, who often proves too formidable for him.

\section{ILLUSTRATIVE ANECDOTES.}

A few days ago (says Mr. Wilson), a Crow was observed eagerly attempting to seize some young chickens in an orchard, near the room where I write; but these clustering close round the hen, she resolutely defended them, drove the Crow into an apple-tree, whither she instantly pursued him with such spirit and intrepidity, that he was glad to make a speedy retreat, and abandon his design.

The Crow himself sometimes falls a prey to the superior strength and rapacity of the great owl, whose weapons of offence are by far the more formidable of the two.

"A few years ago," says a correspondent of Mr. Wilson, "I resided on the banks of the Hudson, about seven miles from the city of New York. Not far from the place of my residence was a pretty thick wood or swamp, in which great numbers of Crows, who used to cross the river from the opposite shore, were accustomed to roost. Returning homeward one afternoon, from a shooting excursion, I had occasion to pass through this swamp. It was near sunset, and troops of Crows were flying in all directions over my head. While engaged in observing their flight, and endeavouring to select from among them an object to shoot at, my ears were suddenly assailed by the distressful cries of a Crow, who was evidently struggling under the talons of a merci- 
less and rapacious enemy. I hastened to the spot whence the sounds proceeded, and, to my great surprise, found a Crow lying on the ground, just expiring, and, seated upon the body of the yet warm and bleeding quarry, a large brown owl, who was beginning to make a meal of the unfortunate robber of corn-fields. Perceiving my approach, he forsook his prey with evident reluctance, and flew into a tree at a little distance, where he sat watching all my movements, alternately regarding, with longing eyes, the victim he had been forced to leave, and darting at me no very friendly looks, that seemed to reproach me for having deprived him of his expected regale.

"I confess that the scene before me was altogether novel and surprising. I am but little conversant with natural history; but I had always understood, that the depredations of the owl were confined to the smaller birds, and animals of the lesser kind, such as mice, young rabbits, \&c., and that he obtained his prey rather by fraud and stratagem, than by open rapacity and violence. I was the more confirmed in this belief, from the recollection of a passage in Macbeth, which now forcibly recurred to my memory. The courtiers of King Duncan are recounting to each other the various prodigies that preceded his death, and one of them relates to his wondering auditors, that

An eagle, towering in his pride of place,

Was by a mousing owl hawked at and killed. 
But to resume my relation: That the owl was the murderer of the unfortunate Crow, there could be no doubt. No other bird of prey was in sight; I had not fired my gun since I entered the wood; nor heard any one else shoot: besides, the unequivocal situation in which I found the parties, would have been sufficient, before any 'twelve good men and true,' or a jury of Crows, to have convicted him of his guilt. It is proper to add, that I avenged the death of the hapless Crow, by a well-aimed shot at the felonious robber, that extended him breathless on the ground."

\section{THE WHIP-POOR-WILL. (Caprimulgus vociferus.)}

THIs celebrated bird is common in various parts of the United States. Its name is derived from its notes, which seem pretty plainly to articulate the words whip-poor-will, the first and last syllable being uttered with great emphasis, and the whole in about a second to each repetition. It has been sometimes confounded with the two other species of the genus, the church-will's-widow and the night-hawk. Mr. Wilson, however, has settled the question, by examining and accurately describing the different species. The Whip-poor-will is nine inches long and nineteen in extent; the bill is blackish, a quarter of an inch long, much stronger 
than that of the night-hawk, and bent at the point. The mouth is very large, and beset on the sides with long elastic bristles, which serve as feelers and prevent the escape of the winged insects on which it feeds. Our engraving shows its figure in flight, and its curious markings.

The Whip-poor-will is never seen during the day, unless in circumstances such as have been described. Their food appears to be large moths, grasshoppers, pismires, and such insects as frequent the bark of old rotten and decaying timber. They are also expert in darting after winged insects. They will sometimes skim in the dust, within a few feet of a person, uttering a kind of Iow chatter as they pass. In their migrations north, and on their return, they probably stop a day or two at some of their former stages, and do not advance in one continued flight.

\section{ILLUSTRATIVE ANECDOTE.}

The following little incident, narrated by Mr. Wilson, illustrates at once a trait in the character of the bird, and the gentle and humane disposition of the naturalist:

In traversing the woods one day in the early part of June, along the brow of a rocky declivity, a Whip-poorwill rose from my feet, and fluttered along, sometimes prostrating herself, and beating the ground with her wings, as if just expiring. Aware of her purpose, I stood still, and began to examine the space immediately around me for 
the eggs or young, one or other of which I was certain must be near. After a long search, to my mortification, I could find neither; and was just going to abandon the spot, when I perceived somewhat like a slight mouldiness among the withered leaves, and, on stooping down, discovered it to be a young Whip-poor-will, seemingly asleep, as its eyelids were nearly closed; or perhaps this might only be to protect its tender eyes from the glare of day. I sat down by it on the leaves, and drew it as it then appeared. It was probably not a week old. All the while I was thus engaged, it neither moved its body, nor opened its eyes more than half; and I left it as I found it. After I had walked about a quarter of a mile from the spot, recollecting that I had left a pencil behind, I returned and found my pencil, but the young bird was gone.

\section{THE CUCKOO. (Cuculus canorus.)}

The third order of birds, Scansores, or Climbers, includes some species which are very interesting. Of these we will first notice the English Cuckoo. She is twelve inches in length from the tip of the bill to the end of the tail; yellow breast, with transverse lines; head, wings, and body marked with black and tawny stripes, legs short and covered 
with feathers. The curious part of this bird's history is the fact that the female does not build a nest, but lays her eggs in that of another bird, generally the sparrow.

The American Cuckoo, or Cow-bird, is quite different in its habits from the European Cuckoo, as it buildsı a nest for its eggs, and hatches its young itself, like other birds.

On the 18th June, 1787, Dr. Jenner examined a nest of a hedge-sparrow, which then contained a Cuckoo's and three hedge-sparrow's eggs. On inspecting it the day following, the bird had hatched; but the nest then contained only a young Cuckoo and one young hedge-sparrow. The nest was placed so near the extremity of a hedge, that he could distinctly see what was going forward in it; and, to his great astonishment, he saw the young Cuckoo, though so lately hatched, in the act of turning out the young hedgesparrow.

The mode of accomplishing this was curious: the little animal, with the assistance of its rump and wings, contrived to get the bird upon its back, and making a lodgment for its burden by elevating its elbows, climbed backward with it up the side of the nest, till it reached the top; where, resting for a moment, it threw off its load with a jerk, and quite disengaged it from the nest. After remaining a short time in this situation, and feeling about with the extremities of its wings, as if to be convinced that the business was properly executed, it dropped into the nest again.

Dr. Jenner made several experiments in different nests, 
by repeatedly putting in an egg to the young Cuckoo; which he always found to be disposed of in a similar manner.

\section{THE KINGFISHER. (Alcedo ispida.)}

THIs bird is nearly as small as a common sparrow, but the head and beak appear proportionally too big for the body. The bright blue of the back and wings claims our admiration, as it changes into deep purple or lively green, according to the angles of light under which the bird presents itself to the eye. It is generally seen on the banks of rivers, for the purpose of seizing small fish, on which it subsists, and which it takes in amazing quantities, by balancing itself at a distance above the water for a certain time, and then darting on the fish with unerring aim. It dives perpendicularly into the water, where it continues several seconds, and then brings up the fish, which it carries to the land, beats to death, and afterwards swallows. When the bird cannot find a projecting bough, it sits on some stone near the brink, or even on the gravel; but the moment it perceives the fish, it takes a spring upwards of twelve or fifteen feet, and drops from that height upon its prey. 


\section{THE GREEN WOODPECKER, (Picus viridis,)}

RECEIVEs his name from the facility with which he pecks the insects from the chinks of trees and holes in the bark. The bill is straight, strong, and angular at the end; and in most of the species is formed like a wedge, for the purpose of piercing the trees. The nostrils are covered with bristles. The tongue is very long, slender, cylindrical, bony, hard, and jagged at the end. The toes are placed two forward and two backward; and the tail consists of ten hard, stiff, and sharp-pointed feathers. A Woodpecker is often seen hanging by his claws, and resting upon his breast against the stem of a tree; when, after darting, with great strength and noise, his beak against the bark, he runs round the tree with great alacrity, which manouvre has made the country people suppose that he goes round to see whether he has not pierced the tree through its trunk; though the fact is, the bird is in search of the insects, which he hopes to have driven out by his blow.

\section{THE TOUCAN, (Ramphastos tucanus,)}

Is a native of South America, very conspicuous for the magnitude and shape of his bill. It is about the size of 
the magpie, but the beak alone is nearly as big as the rest of the body; the head is large and strong, and the neck short, in order the more easily to support the bulk of such a beak. The head, neck, and wings are black; the breast shines with a most lovely saffron colour, with a certain redness near the beginning; the lower part of the body and the thighs are of a most beautiful vermilion; the tail is black, but of a bright red at the end.

One of these birds that was kept in a cage was very fond of fruit, which it held for some time in its beak, touching it with great delight with the tip of its feathery tongue, and then tossing them into its throat by a sudden upright jerk; it also fed on birds and other small animals.

\section{CAROLINA PARROT. (Psittacus Carolinensis.)}

OF one hundred and sixty-eight kinds of Parrots (says Wilson) enumerated by writers as inhabiting the various regions of the globe, this is the only species found native within the territory of the United States. Our engraving shows that this bird has a far more elegant form than the imported parrots which we see in cages. It is thirteen inches long and twenty-one in extent; its forehead and cheeks are orange red; beyond this, for an inch and a half 


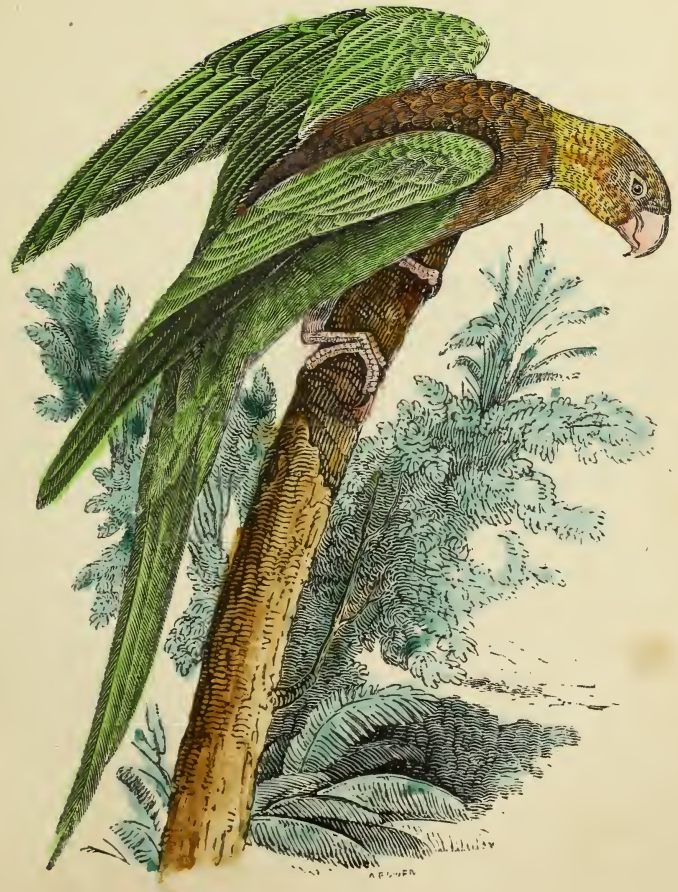



down and round the neck, a rich and pure yellow; shoulder and bend of the wing, also edged with rich orange red. The general colour of the rest of the plumage is a bright yellowish, silky green, with light blue reflections; feet a pale flesh-colour; bill white, inclining to cream-colour. It is found in the Southern and Western States.

\section{ILLUSTRATIVE ANECDOTES.}

Mr. Wilson gives the following very lively account of the captive state of one of these birds:-

Anxious to try the effects of education on one of those which I had procured at Big Bone Lick, and which was but slightly wounded in the wing, I fixed up a place for it in the stern of my boat, and presented it with some cockle burs, which it freely fed on in less than an hour after being on board. The intermediate time between eating and sleeping was occupied in gnawing the sticks that formed its place of confinement, in order to make a practicable breach; which it repeatedly effected. When I abandoned the river, and travelled by land, I wrapped it up closely in a silk handkerchief, tying it tightly around, and carried it in my pocket.

When I stopped for refreshment, I unbound my prisoner, and gave it its allowance, which it generally despatched with great dexterity, unhusking the seeds from the bur in a twinkling; in doing which, it always employed its left foot to hold the bur, as did several others that I kept for 
some time. I began to think that this might be peculiar to the whole tribe, and that the whole were, if I may use the expression, left-footed; but, by shooting a number afterwards while engaged in eating mulberries, I found sometimes the left, sometimes the right, foot stained with the fruit, the other always clean ; from which, and the constant practice of those I kept, it appears, that, like the human species in the use of their hands, they do not prefer one or the other indiscriminately, but are either left or right-footed.

But to return to my prisoner: In recommitting it to "durance vile," we generally had a quarrel; during which it frequently paid me in kind for the wound I had inflicted, and for depriving it of liberty, by cutting and almost disabling several of my fingers with its sharp and powerful bill. The path through the wilderness between Nashville and Natchez is in some places bad beyond description. There are dangerous creeks to swim, miles of morass to struggle through, rendered almost as gloomy as night by a prodigious growth of timber, and an underwood of canes and other evergreens; while the descent into these sluggish streams is often ten or fifteen feet perpendicular, into a bed of deep clay. In some of the worst of these places, where I had, as it were, to fight my way through, the Paroquet frequently escaped from my pocket, obliging me to dismount and pursue it through the worst of the morass before I could regain it. On these occasions, I was several times 
tempted to abandon it; but I persisted in bringing it along.

When at night I encamped in the woods, I placed it on the baggage beside me, where it usually sat with great com posure, dozing and gazing at the fire till morning. In this manner I carried it upwards of a thousand miles, in $\mathrm{m}$ J pocket, where it was exposed all day to the jolting of th horse, but regularly liherated at meal-times and in the evening, at which it always expressed great satisfaction In passing through the Shickasaw and Choctaw nations, the Indians, wherever I stopped to feed, collected around me, men, women, and children, laughing, and seeming wonderfully amused with the novelty of my companion. The Chickasaws called it in their language "Kelinky;" but when they heard me call it Poll, they soon repeated the name; and wherever I chanced to stop among these people, we soon became familiar with each other through the medium of Poll.

On arriving at Mr. Dunbar's, below Natchez, I procured a cage, and placed it under the piazza, where, by its call, it soon attracted the passing flocks; such is the attachment they have for each other. Numerous parties frequently alighted on the trees immediately above, keeping up a constant conversation with the prisoner. One of these I wounded slightly in the wing, and the pleasure Poll expressed on meeting with this new companion was really amusing. She crept close up to it as it hung on the side 
of the cage; chattered to it in a low tone of voice, as if sympathizing in its misfortune; scratched about its head and neck with her bill; and both at night nestled as close as possible to each other, sometimes Poll's head being thrust among the plumage of the other. On the death of this companion, she appeared restless and inconsolable for several days.

On reaching New Orleans, I placed a looking-glass beside the place where she usually sat, and the instant she perceived her image, all her former fondness seemed to return, so that she could scarcely absent herself from it a moment. It was evident that she was completely deceived. Always when evening drew on, and often during the day, she laid her head close to that of the image in the glass, and began to doze with great composure and satisfaction. In this short space she had learned to know her name; to answer, and come when called on; to climb up my clothes, sit on my shoulder, and eat from my mouth. I took her with me to sea, determined to persevere in her education; but, destined to another fate, poor Poll, having one morning, about day-break, wrought her way through the cage, while I was asleep, instantly flew overboard and perished in the Gulf of Mexico. 


\section{THE PEACOCK. (Pavo cristatus.)}

The Gallinaceous birds (Rasores) form the fourth order, which includes many of the domestic fowls, and others useful to man. The Peacock is the most celebrated of the order, the beauty of its plumage having rendered it a favourite in all ages of the world; indeed, there is scarcely anything in nature that can vie with the transcendent lustre of the Peacock's feathers. The changing glory of his neck eclipses the deep azure of ultramarine; and at the least evolution, it assumes the green tint of the emerald, and the purple hue of the amethyst. His head, which is small and finely shaped, has several curious stripes of white and black round the eyes, and is surmounted by an elegant plume, or tuft of feathers, each of which is composed of a slender stem and a small tuft at the top. Displayed with conscious pride, and exposed under a variety of angles to the reflections of versatile light, the broad and variegated disks of his tail, of which the neck, head, and breast of the bird become the centre, claims our well merited admiration. By an extraordinary mixture of the brightest colours, it displays at once the richness of gold, and the paler tints of silver, fringed with bronze-coloured edges, and surrounding eyclike spots of dark brown and sapphire. The female does not share in the beauty of the cock, and her feathers are generally of a light brown. She lays only a few eggs at a time, and these at a distance of usually three or four days 
from each other; they are white and spotted, like the eggs of the turkey. She sits from twenty-seven to thirty days.

The loud screamings of the Peacock are worse than the harsh croakings of the raven, and a sure prognostic of bad weather; and his feet, more clumsy than those of the turkey, make a sad contrast with the elegance of the rest.

\section{THE TURKEY, (Meleagris Gallo-Pavo,)}

WAS originally an inhabitant of America, whence he was brought to Europe by some Jesuit missionaries, which accounts for his being called a Jesuit in some parts of continental Europe. Except the tuft on the head, which he does not share with the peacock, and his plumage, which is very different from that of the latter, he is like him in many particulars. The general colour of the feathers is brown and black; and turkeys have about the head, especially the cock, naked and tuberous lumps of flesh of a bright red colour. A long fleshy appendage hangs from the base of the upper mandible, and seems to be lengthened and shortened at pleasure. The hen lays from fifteen to twenty eggs, which are whitish and freckled. The chickens are very tender, and require great care and attentive nursing, before they are able to seek their food. 


\section{THE PINTADO.}

The wild Turkey-cock is, in our American forests, an object of considerable interest. It perches on the tops of the deciduous cypress and magnolias.

\section{ILLUSTRATIVE ANECDOTE.}

A gentleman of New York received from a distant part a Turkey-cock and hen, and with them a pair of bantams; which were put all together into the yard with his other poultry. Some time afterward, as he was feeding them from the barn-door, a large hawk suddenly turned the corncr of the barn, and made a pounce at the bantam hen; she immediately gave the alarm, by a noise which is natural to her on such occasions; when the Turkey-cock, who was at the distance of about two yards, and without doubt understood the hawk's intention, flew at the tyrant with such violence, and gave him so severe a stroke with his spurs, as to knock him from the hen to a considerable distance; by which means the bantam was rescued from destruction.

\section{THE PINTADO, or GUINEA HEN. (Numida Meleagris.)}

THe Pintado is somewhat larger than the common hen; the head is bare of feathers, and covered with a naked 
88

skin of a bluish colour; on the top is a callous protuberance of a conical form. At the base of the bill on each side hangs a loose wattle, red in the female and bluish in the male. The general colour of the plumage is a dark bluish gray, sprinkled with round white spots of different sizes, resembling pearls, from which circumstance the epithet of pearled has been applied to this bird; which, at first sight, appears as if it had been pelted by a strong shower of hail. These spots, which we find of a larger dimension upon some of the feathers of the pheasant, and bigger still on the tail of the peacock, are convincing proofs of a near relationship between these fowls.

\section{ILLUSTRATIVE ANECDOTE.}

M. Brue informs us, that when he was on the coast of Senegal, he received, as a present from an African princess, two Guinea fowls. Both these birds were so familiar that they would approach the table and eat out of his plate; and, when they had liberty to fly about upon the beach, they always returned to the ship when the dinner or supper bell rang.

In a wild state it is asserted that the Pintado associates in numerous flocks. Dampier speaks of having seen betwixt two and three hundred of them together in the Cape de Verd Islands. 


\section{THE TAME PIGEON. (Columba livia.)}

PAssing over the common barn fowl and the partridge, pheasant, quail, and grouse, we come to the common tame Pigeon, as a specimen of the genus Columba, of which there are many species. The tame Pigeon is well known as to the shape, but the colour varies so much, that it eludes the rules of classification. They prefer a gregarious life, and abide often, to the number of five or six thousand, in a cot purposely built for them in the neighbourhood of a farmyard, with proper holes to nestle in. The female Pigeon, through the whole species, lays two eggs at a time, which produce generally a male and a female. It is pleasing to see how eager the male is to sit upon the eggs, in order that his mate may rest and feed herself. The young ones, when hatched, require no food for the first three days, warmth is their only nourishment; they are then fed from the crop of the mother; who has the power of forcing up the half-digested peas which she has swallowed to give them to her young. The young ones, open-mouthed, receive this tribute of affection, and are thus fed three times a day.

\section{ILLUSTRATIVE ANECDOTE.}

There are upwards of twenty varieties of the domestic Pigeon, and of these ths Carriers are the most celebrated. They obtain their name from being sometimes employed to 
convey letters or small packets from one place to another. The rapidity of their flight is very wonderful. Leithgow assures us that one of them will carry a letter from Babylon to Aleppo (which, to a man, is usually thirty days' journey) in forty-eight hours. To measure their speed with some degree of exactness, a gentleman many years ago, on a trifling wager, sent a Carrier Pigeon from London, by the coach, to a friend at Bury St. Edmond's ; and along with it a note, desiring that the Pigeon, two days after its arrival there, might be thrown up precisely when the town clock struck nine in the morning. This was accordingly done, and the Pigeon arrived in London at half-past eleven o'clock of the same morning, having flown seventy-two miles in two hours and a half. From the instant of its liberation, its flight is directed through the clouds, at a great height, to its home. By an instinct altogether inconceivable, it darts onward, in a straight line, to the very spot whence it was taken, but how it can direct its flight so exactly will probably for ever remain unknown to us.

\section{THE OSTRICH. (Struthio camelus.)}

We place the Ostrich at the head of the fifth order of birds, the Grallatores, or Waders. The Ostrich is a native of Africa. It is one of the tallest of birds; as when it 
holds up its head it can reach eleven feet in height. The head is very small in comparison with the body, being hardly bigger than one of the toes; it is covered, as well as the neck, with a certain down, or thin-set hairs, instead of feathers. The sides and thighs are entirely bare and fleshcoloured. The lower part of the neck, where the feathers begin, is white. The wings are short and of no use in flying, but when the bird runs, which it does with a strange jumping kind of motion, it raises its short wings, and holds them quivering over its back, where they seem to serve as a kind of sail to gather the wind and carry the bird onwards. The feathers of the back, in the cock, are coalblack; in the hen only dusky, and so soft that they resemble a kind of wool. The tail is thick, bushy, and round; in the cock whitish, in the hen dusky with white tops. These are the feathers so generally in requisition, to decorate the head-dress of ladies and the helmets of warriors.

The Ostrich swallows anything that presents itself, leather, glass, iron, bread, hair, \&c. ; and the power of digestion in the stomach is so strong that even iron is very much affected by it. An Ostrich in the Zoological Gardens in the Regent's Park, was, however, killed by swallowing a lady's parasol.

0'er the wild waste the stupid Ostrich strays,

In devious search to pick her scanty meal,

Whose fierce digestion gnaws the temper'd steel. 
They are polygamous birds; one male being generally seen with two or three, and sometimes with five females. The female Ostrich, in the tropical regions, after depositing her eggs in the sand, trusts them to be hatched by the heat of the climate, and leaves the young ones to provide for themselves.

\section{ILLUSTRATIVE ANECDOTES.}

That Ostriches have great affection for their offspring, may be inferred from the assertion of Professor Thunberg, that he once rode past the place where a hen Ostrich was sitting in her nest; when the bird sprang up and pursued him, evidently with a view to prevent his noticing her eggs or young. Every time he turned his horse towards her, she retreated ten or twelve paces; but as soon as he rode on again, she pursued him, till he had got to a considerable distance from the place where he had started her. In the tropical regions, some persons breed Ostriches in flocks; for they may be tamed with very little trouble; and in their domestic state, few animals may be rendered more useful. When M. Adanson was at Podar, a French factory on the southern bank of the river Niger, two young but full-grown Ostriches, belonging to the factory, afforded him a very amusing sight. They were so tame that two little blacks mounted both together on the back of the largest. No sooner did he feel their weight, than he began to run as fast as possible, and carried them several times round the village; 
and it was impossible to stop him otherwise than by obstructing the passage. This sight pleased M. Adanson so much, that he wished it to be repeated; and to try their strength, he directed a full-grown negro to mount the smaller, and two others the larger of the birds. This burden did not seem at all disproportioned to their strength. At first, they went at a tolerably sharp trot; but when they became heated a little, they expanded their wings, as though to catch the wind, and moved with such fleetness that they scarcely seemed to touch the ground. The foot of the Ostrich has only two toes; one of which is extremely large and strong, to make its way through the moving sands of the desert.

\section{THE CASSOWARY, (Casuarius galeatus,)}

Is next in size to the ostrich, but of a different nature. His wings are hardly perceptible, being very short, and entirely concealed under the plumage. The general tint of his feathers is brown, with some spots of vermilion red; his head is small and depressed, with a horny crown; the head and neck are deprived of feathers, and only set with a kind of hairy down. From the bill to the claws the body measures about five feet and a half; about the neck are two protuberances of a bluish colour, and in shape like the 


\section{THE WHOOPING CRANE.}

wattles of a cock. Unlike other birds, the feathers of the wings, and other parts of the body, are exactly the same; so that at a distance he looks rather as if he were entirely covered with hairs like a bear, than with plumage like a bird. The Cassowary eats indiscriminately whatever comes in his way, and does not seem to have any sort of predilection in the choice of his food. He is a native of the southern parts of India; the eggs of the female are nearly fifteen inches in circumference, of a grayish ash-colour, marked with green. It has been said of the Cassowary, that he has the head of a warrior, the eye of a lion, the armament of a porcupine, and the swiftness of a courser.

\section{THE WHOOPING CRANE. (Grus Americana.)}

THIs stately Crane (says Mr. Nuttall), the largest of all the feathered tribes in the United States, like the rest of its family, dwelling amidst marshes, and dark and desolate swamps, according to the season, is met with in almost every part of North America, from the islands of the West Indies, to which it retires to pass the winter, to the utmost habitable regions and fur countries of the North. A few hybernate in the warmer parts of the Union, and some have been known to linger through the whole of the inclement season in the swamps of New Jersey, near to Cape May. When dis- 


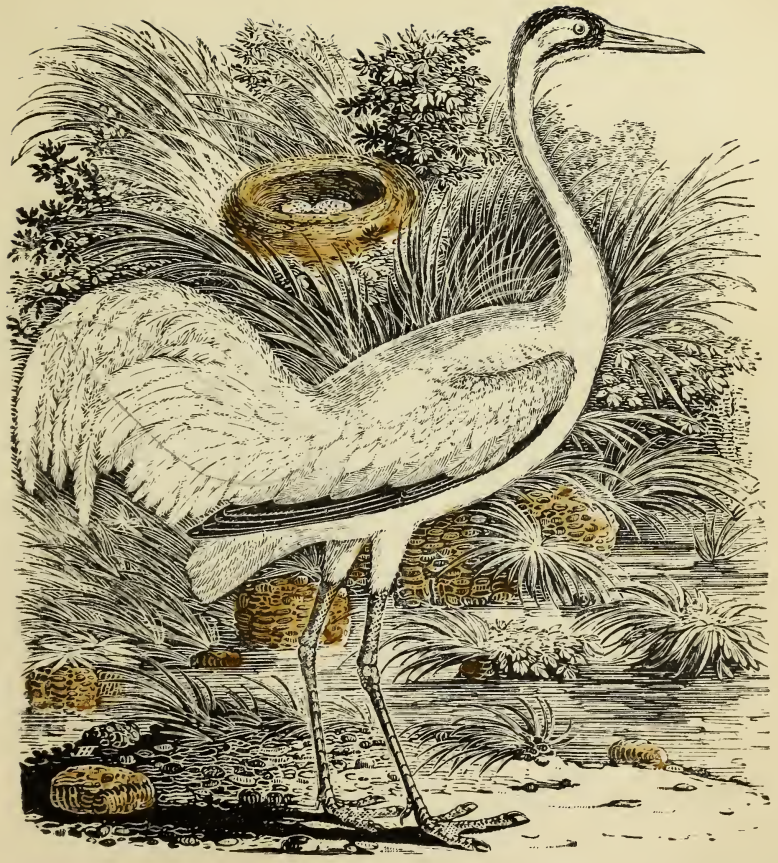



covered in their retreats, they are observed wandering along the marshes and muddy flats near the sea-shore, in quest of reptiles, fish, and marine worms. Occasionally they are seen sailing along from place to place with a heavy, silent flight, elevated but little above the surface of the earth. Ever wary, and stealing from the view of all observers, these gaunt shades of something which constantly avoids the social light, impress the mind no less with curiosity than aversion, and it is surprising, that furtive and inharmonious as owls, they have not excited the prejudice of the superstitious.

At times they utter a loud, clear, and piercing cry, that may be heard to a very considerable distance, and which, being not unaptly compared to the whoop or yell of the savages when rushing to battle, has conferred upon our bird his peculiar appellation. Other species of the genus possess also the same sonorous cry. When wounded, they attack those who approach them with considerable vigour, so much so as to have been known to dart their sharp and dagger-like bill through the incautious hand held out for their capture. Indeed, according to Dr. Richardson, they have sometimes driven the fowler fairly out of the field.

\section{ILLUSTRATIVE ANECDOTES.}

Captain Amidas (the first Englishman who ever set foot in North America) thus graphically describes the clamour of the Whooping Cranes, on his landing on the isle of Wo- 
kokou, off the coast of North Carolina, in the month of July: "Such a flock of Cranes (the most part white) arose under us, with such a cry, redoubled by many echoes, as if an armiy of men had shouted altogether." But though this display of their discordant calls may be amusing, the bustle of their great migrations, and the passage of their mighty armies, fills the mind with wonder.

In the month of December, 1811 (says Mr. Nuttall), while leisurely descending on the bosom of the Mississippi, in one of the trading boats of that period, I had an opportunity of witnessing one of these vast migrations of the Whooping Cranes, assembled by many thousands from all the marshes and impassable swamps of the north and west. The whole continent seemed as if giving up its quota of the species to swell the mighty host. Their flight took place in the night, down the great aerial valley of the river, whose southern course conducted them every instant towards warmer and more hospitable climes. The clangour of these numerous legions passing along, high in air, seemed almost deafening; the confused cry of the vast army continued, with the lengthening procession, and as the vocal call continued nearly throughout the whole night, without intermission, some idea may be formed of the immensity of the numbers now assembled on their annual journey to the regions of the south. 



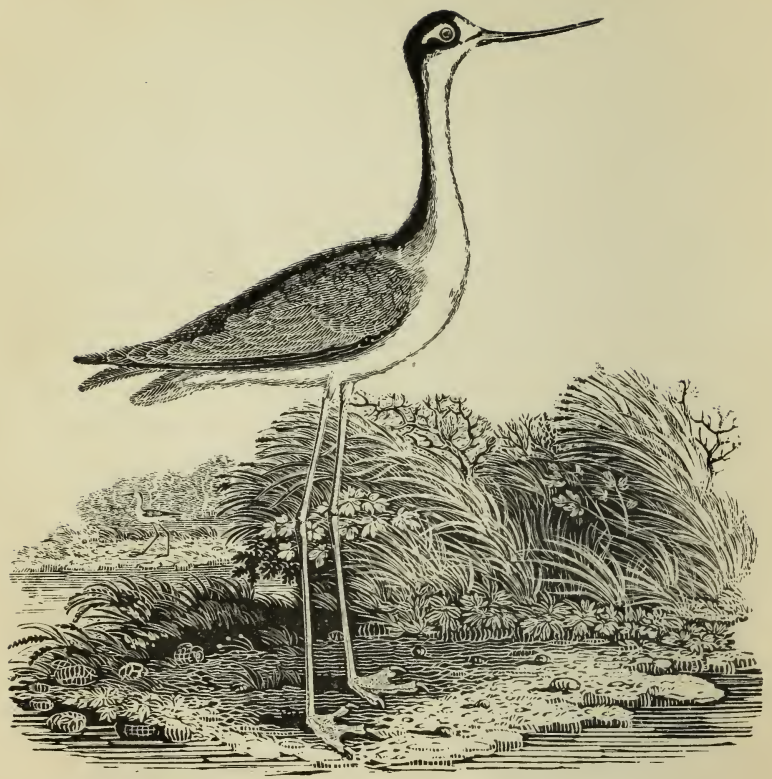




\section{THE BLACK-NECKED STILT. \\ (Himantopus nigricollis.)}

THIs curious bird, under the name of Long-legged Avoset, is described by Mr. Wilson in his usual lively and interesting style. He says :-

This species arrives on the sea-coast of New Jersey about the 25th of April, in small, detached flocks, of twenty or thirty together. These sometimes again subdivide into lesser parties; but it rarely happens that a pair is found solitary, as, during the breeding season, they usually associate in small companies. On their first arrival, and, indeed, during the whole of their residence, they inhabit those particular parts of the salt marshes pretty high up towards the land, that are broken into numerous shallow pools, but are not usually overflowed by the tides during the summer. These pools, or ponds, are generally so shallow, that, with their long legs, the Avosets can easily wade them in every direction; and, as they abound with minute shell-fish, and multitudes of aquatic insects and their larvæ, besides the eggs and spawn of others deposited in the soft mud below, these birds find here an abundant supply of food, and are almost continually seen wading about in such places, often up to the breast in water.

In the vicinity of these bald places, as they are called by the country people, and at the distance of forty or fifty yards off, among the thick tufts of grass, one of these small 
associations, consisting perhaps of six or eight pair, takes up its residence during the breeding season. About the first week in May they begin to construct their nests, which are at first slightly formed of a small quantity of old grass, scarcely sufficient to keep the eggs from the wet marsh. As they lay and sit, however, either dreading the rise of the tides, or for some other purpose, the nest is increased in height, with dry twigs of a shrub very common in the marshes, roots of the salt grass, sea-weed, and various other substances, the whole weighing between two and three pounds. This habit of adding materials to the nest after the female begins sitting, is common to almost all other birds that breed in the marshes. The eggs are four in number, of a dark yellowish clay-colour, thickly marked with large blotches of black. These nests are often placed within fifteen or twenty yards of each other; but the greatest harmony seems to prevail among the proprietors.

While the females are sitting, the males are either wading through the ponds, or roaming over the adjoining marshes; but should a person make his appearance, the whole collect together in the air, flying with their long legs extended behind them, keeping up a continual yelping note of click, click, click. Their flight is steady, and not in short, sudden jerks, like that of the plover. As they frequently alight on the bare marsh, they drop their wings, stand with their legs half bent, and trembling, as if unable to sustain the burden of their bodies. In this ridiculous posture they 
. 


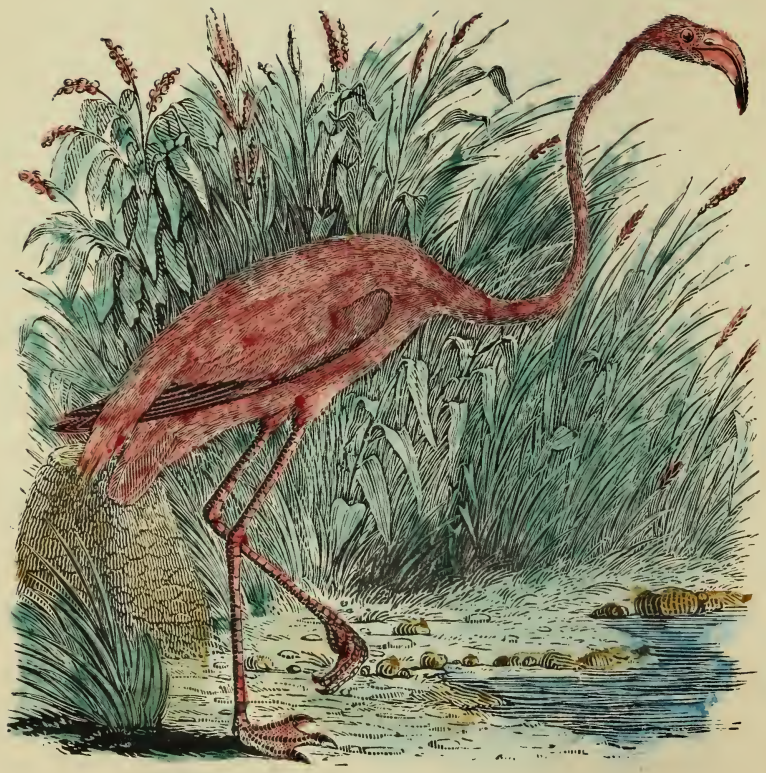


will sometimes stand for several minutes, uttering a curring sound, while, from the corresponding quiverings of their wings and long legs, they seem to balance themselves with great difficulty. This singular manouvre is, no doubt, intended to induce a belief that they may be easily caught, and so turn the attention of the person, from the pursuit of their nests and young, to themselves.

The Red-necked Avoset practises the very same deception, in the same ludicrous manner, and both alight indiscriminately on the ground or in the water. Both will also occasionally swim for a few feet, when they chance in wading to lose their depth, as I have had several times an opportunity of observing.

The name by which this bird is known on the sea-coast is the Stilt, or Tilt, or Long-Shanks. They are but sparingly dispersed over the marshes, having, as has been already observed, their particular favourite spots, while in large intermediate tracts, there are few or none to be found.

\section{THE AMERICAN, OR RED FLAMINGO. (Phoenicopterus ruber.)}

The Flamingo of America (says Mr. Nuttall) is found chiefly in the tropical regions, from whence it appears to 
emigrate in summer, on either side of the equator; in the southern hemisphere, visiting Brazil, Peru, Chili, and Buenos Ayres, on the shores of La Plata. It is also seen in Cayenne (where it is known by the name of Tococo, from the usual sound of its call), and in various islands of the West Indies. They breed in Cuba and the Bahamas, are not unfrequent at certain seasons on the coast of Florida, and sometimes solitary individuals are observed even in the Middle States; but in the Union generally, the species may be considered as rare.

When seen at a distance, such is the brilliancy of their dress, and the elevation at which they stand, that they appear like a troop of soldiers, being arranged alongside of each other, in lines, while on the borders of rivers and estuaries near the sea, they assemble in search of their food, which consists chiefly of small fish, spawn, and aquatic insects.

They collect their prey by plunging in the bill and part of the head; and from time to time trample with their feet, to disturb the water, and raise it from the bottom. While the rest are thus employed in seeking their subsistence, one of them stands sentinel, and, on the first note of alarm, a kind of trumpet-call, he takes to wing, and the whole flock immediately follow.

The Flamingo has the neck and legs in a greater disproportion than any other bird. The length from the end of the bill to that of the tail is four feet two or three inches; 
but to the end of the claws measures sometimes more than six feet. The bill is four inches and a quarter long; as far as the bend black, but from thence to the base, reddishyellow; round the base quite to the eye, covered with a flesh-coloured cere.

The plumage deep scarlet in the adult, except the quills, wnich are black. From the base of the thigh to the claws, measures thirty-two inches, of which the feathered part takes up no more than three.

\section{WILSON'S STORMY PETREL. (ThalasidromaWilsonii.)}

We commence our series of the Palmipedes, or WebFooted birds, with this, which is called Wilson's Stormy Petrel, in honour of Alexander Wilson, the celebrated historian of American birds. It is on his authority that we give the following description and illustrative anecdotes:-

The Stormy Petrel, the least of the whole twenty-four species of its tribe enumerated by ornithologists, and the smallest of all palmated fowls, is found over the whole Atlantic Ocean, from Europe to North America, at all distances from land, and in all weathers, but is particularly numerous near vessels, immediately preceding and during a gale, when flocks of them crowd in her wake, seeming then 
102 THE STORMY PETREL.

more than usually active in picking up various matters from the surface of the water.

The Stormy Petrels, or Mother Carey's Chickens, breed in great numbers on the rocky shores of the Bahama and the Bermuda Islands, and in some places on the coast of East Florida and Cuba. They breed in communities, like the bank swallows, making their nests in the holes and cavities of the rocks above the sea, returning to feed their young only during the night, with the superabundant oily food from their stomachs. At these times they may be heard making a continued cluttering sound, like frogs, during the whole night. In the day they are silent, and wander widely over the ocean. This easily accounts for the vast distance they are sometimes seen from land, even in the breeding season. The rapidity of their flight is at least equal to the fleetness of our swallows. Calculating this at the rate of one mile per minute, twelve hours would be sufficient to waft them a distance of seven hundred and twenty miles; but it is probable that the far greater part confine themselves much nearer land during that interesting period.

\section{ILLUSTRATIVE ANECDOTES.}

In the month of July, while on a voyage from New Orleans to New York, I saw few or none of these birds in the Gulf of Mexico, although our ship was detained there by calms for twenty days, and carried by currents as far 
south as Cape Antonio, the westernmost extremity of Cuba. On entering the Gulf Stream, and passing along the coasts of Florida and the Carolinas, these birds made their appearance in great numbers, and in all weathers, contributing much by their sprightly evolutions of wing to enliven the scene, and affording me every day several hours of amusement. It is indeed an interesting sight to observe these little birds in a gale, coursing over the waves, down the declivities, up the ascents of the foaming surf that threatens to burst over their heads, sweeping along the hollow troughs of the sea as in a sheltered valley, and again mounting with the rising billow, and just above its surface occasionally dropping its feet, which, striking the water, throw it up again with additional force; sometimes leaping, with both legs parallel, on the surface of the roughest waves for several yards at a time. Meanwhile it continues coursing from side to side of the ship's wake, making excursions far and wide, to the right and to the left, now a great way ahead, and now shooting astern for several hundred yards, returning again to the ship as if she were all the while stationary, though perhaps running at the rate of ten knots an hour! But the most singular peculiarity of this bird is its faculty of standing, and even running, on the surface of the water, which it performs with apparent facility. When any greasy matter is thrown overboard, these birds instantly collect around it, and, facing to windward, with their long wings expanded, and their webbed feet patting the water, the lightness of - 
their bodies and the action of the wind on their wings enable them to do this with ease. In calm weather, they perform the same manœuvre, by keeping their wings just so much in action as to prevent their feet from sinking below the surface. According to Buffon, it is from this singular habit that the whole genus have obtained the name Petrel, from the Apostle Peter, who, as Scripture informs us, also walked on the water.

As these birds often come up immediately under the stern, one can examine their form and plumage with nearly as much accuracy as if they were in the hand. They fly with the wings forming an almost straight, horizontal line with the body, the legs extended behind, and the feet partly seen stretching beyond the tail. Their common note of "weet, weet," is scarcely louder than that of a young duck of a week old, and much resembling it. During the whole of a dark, wet, and boisterous night which I spent on deck, they flew about the after rigging, making a singular hoarse chattering, which in sound resembled the syllables patrèt tu $c u k c u k$, $t u t u$, laying the accent strongly on the second syllable tret. Now and then I conjectured that they alighted on the rigging, making then a lower, curring noise.

Notwithstanding the superstitious fears of the seamen, who dreaded the vengeance of the survivors, I shot fourteen of these birds one calm day, in lat. $33^{\circ}$, eighty or ninety miles off the coast of Carolina, and had the boat lowered to pick them up. These I examined with consider- 
able attention, and found the most perfect specimens as follows :-

Length, six inches and three quarters; extent, thirteen inches and a half; bill, black, nostrils, united in a tubular projection, the upper mandible grooved from thence, and overhanging the lower like that of a bird of prey; head, back, and lower parts, brown sooty black; greater wingcoverts, pale brown, minutely tipped with white; sides of the vent, and whole tail-coverts, pure white; wings and tail, deep black, the latter nearly even at the tip, or very slightly forked; in some specimens, two or three of the exterior tail-feathers were white for an inch or so at the root; legs and naked part of the thighs, black; feet, webbed, with the slight rudiments of a hind toe ; the membrane of the food is marked with a spot of straw yellow, and finely serrated along the edges; eyes, black. Male and female differing nothing in colour.

\section{THE PIED OYSTER-CATCHER. ostralegus.)}

(Hæmatopus

THIs singular species (says Wilson) although nowhere numerous, inhabits almost every sea-shore, both on the new and old continent, but is never found inland. It is the only one of its genus hitherto discovered, and from the con- 


\section{THE PIED O Y S TER-CA T C II ER.}

formation of some of its parts, one might almost be led by fancy to suppose, that it had borrowed the eye of the pheasant, the legs and feet of the bustard, and the bill of the woodpecker.

The Oyster-Catcher frequents the sandy sea-beach of New Jersey, and other parts of our Atlantic coast, in summer, in small parties of two or three pairs together. They are extremely shy, and, except about the season of breeding, will seldom permit a person to approach within gunshot. They walk along the shore in a watchful, stately manner, at times probing it with their long, wedge-like bills, in search of small shell-fish. This appears evident, on examining the hard sands where they usually resort, which are found thickly perforated with oblong holes, two or three inches in depth. The small crabs called fiddlers, that burrow in the mud at the bottom of inlets, are frequently the prey of the Oyster-Catcher; as are muscles, spout fish, and a variety of other shell-fish and sea insects with which those shores abound.

The principal food, however, of this bird, according to European writers, and that from which it derives its name, is the oyster, which it is said to watch for, and snatch suddenly from the shells, whenever it surprises them sufficiently open. In search of these, it is reported that it often frequents the oyster-beds, looking out for the slightest opening through which it may attack its unwary prey. For this purpose the form of its bill seems very fitly cal- 
culated. Yet the truth of these accounts is doubted by the inhabitants of Egg Harbor, and other parts of our coast, who positively assert, that it never haunts such places, but confines itself almost solely to the sands; and this opinion I am inclined to believe correct, having myself uniformly found these birds on the smooth beach bordering the ocean, and on the higher, dry, and level sands, just beyond the reach of the summer tides. On this last situation, where the dry flats are thickly interspersed with drifted shells, I have repeatedly found their nests, between the middle and 25th of May. The nest itself is a slight hollow in the sand, containing three eggs, somewhat less than those of a hen, and nearly of the same shape, of a bluish cream-colour, marked with large, roundish spots of black, and others of a fainter tint. In some, the ground cream-colour is destitute of the bluish tint, the blotches larger, and of a deep brown. The young are hatched about the 25th of May, and sometimes earlier, having myself caught them running along the beach about that period. They are at first covered with down of a grayish colour, very much resembling that of the sand, and marked with a streak of brownish black on the back, rump, and neck, the breast being dusky, where, in the old ones, it is black. The bill is at that age slightly bent downwards at the tip, where, like most other young birds, it has a hard protuberance that assists them in breaking the shell; but in a few days afterwards this falls off. These run along the shore with great ease and swiftness. 


\section{THE PIED OY STER-CATCHER.}

Latham observes, that the young are said to be hatched in about three weeks; and though they are wild when in flocks, yet are easily brought up tame, if taken young. "I have known them," says he, "to be thus kept for a long time, frequenting the ponds and ditches during the day, attending the ducks and other poultry to shelter of nights, and not unfrequently to come up of themselves as evening approaches."

The female sits on her eggs only during the night, or in remarkably cold and rainy weather; at other times the heat of the sun and of the sand, which is sometimes great, renders incubation unnecessary. But although this is the case, she is not deficient in care or affection. She watches the spot with an attachment, anxiety, and perseverance, that are really surprising, till the time arrives when her little offspring burst their prisons, and follow the guiding voice of their mother. When there is appearance of danger, they squat on the sand, from which they are with difficulty distinguished, while the parents make large circuits around the intruder, alighting sometimes on this hand, sometimes on that, uttering repeated cries, and practising the common affectionate stratagem of counterfeited lameness, to allure him from their young.

\section{ILLUSTRATIVE ANECDOTES.}

Some time ago (says Mr. Wilson) I received a stuffed. specimen of the Oyster-Catcher, from a gentleman of Boston, 
an experienced sportsman, who, nevertheless, was unacquainted with this bird. He informed me, that two very old men to whom it was shown, called it a Hagdel. He adds, "It was shot from a flock, which was first discovered on the beach near the entrance of Boston Harbour. On the approach of the gunner, they rose, and instantly formed in line, like a corps of troops, and advanced in perfect order, keeping well dressed. They made a number of circuits in the air previous to being shot at, but wheeled in line; and the man who fired into the flock, observed that all their evolutions were like those of a regularly-organized military company."

The Oyster-Catcher will not only take to the water when wounded, but can also swim and -dive well. This fact I can assert from my own observation, the exploits of one of them in this way having nearly cost me my life. On the sea-beach of Cape May, not far from a deep and rapid inlet, I broke the wing of one of these birds, and being without a dog, instantly pursued it towards the inlet, which it made for with great rapidity. We both plunged in nearly at the same instant; but the bird eluded my grasp, and I sunk beyond my depth; it was not until this moment that I recollected having carried in my gun along with me. On rising to the surface, I found the bird had dived, and a strong ebb current was carrying me fast towards the ocean, encumbered with a gun and all my shooting apparatus; I was compelled to relinquish my bird, and to make for the 


\section{THE PIED OY STER-CATCHER.}

shore, with considerable mortification, and the total destruction of the contents of my powderhorn. The wounded bird afterwards rose, and swam with great buoyancy out among the breakers.

On the same day, I shot and examined three individuals of this species, two of which measured each eighteen inches in length, and thirty-five inches in extent; the other was somewhat less. The bills varied in length, measuring three inches and three quarters, three and a half, and three and a quarter, thinly compressed at the point, very much like that of the woodpecker tribe, but remarkably narrowed near the base where the nostrils are placed, probably that it may work with more freedom in the sand. This instrument, for two-thirds of its length towards the point, was evidently much worn by digging; its colour, a rich orangescarlet, somewhat yellowish near the tip; eye, large; orbits, of the same bright scarlet as the bill; irides, brilliant yellow; pupil, small, bluish black; under the eye is a small spot of white, and a large bed of the same on the wing-coverts; head, neck, scapulars, rump, wing-quills, and tail, black; several of the primaries are marked on the outer vanes with a slanting band of white; secondaries, white, part of them tipped with black; the whole lower parts of the body, sides of the rump, tail-coverts, and that portion of the tail which they cover, are pure white; the wings, when shut, cover the whole white plumage of the back and rump; legs and naked part of the thighs, pale red; feet, 
three-toed, the outer joined to the middle by a broad and strong. membrane, and each bordered with a rough, warty edge; the soles of the feet are defended from the hard sand and shells by a remarkably thick and callous warty skin.

On opening these birds, the smallest of the three was found to be a male; the gullet widened into a kind of crop; the stomach, or gizzard, contained fragments of shellfish, pieces of crabs, and of the great king-crab, with some dark brown marine insects. The flesh was remarkably firm and muscular; the skull, thick and strong, intended, no doubt, as in the woodpecker tribe, for the security of the brain from the violent concussions it might receive while the bird was engaged in digging. The female and young birds have the back and scapulars of a sooty brownish olive.

\section{THE GREAT HERON. (Ardea Herodias.)}

The Great Heron (says Mr. Wilson) is a constant inhabitant of the Atlantic coast, from New York to Florida; in deep snows and severe weather seeking the open springs of the cedar and cypress swamps, and the muddy inlets occasionally covered by the tides. On the higher inland parts of the country, beyond the mountains, they are less numerous; and one which was shot in the upper parts of $\mathrm{New}$ 
Hampshire, was described to me as a great curiosity. Many of their breeding-places occur in both Carolinas, chiefly in the vicinity of the sea. In the lower parts of New Jersey, they have also their favourite places for building, and rearing their young. These are generally in the gloomy solitudes of the tallest cedar swamps, where, if unmolested, they continue annually to breed for many years. These swamps are from half a mile to a mile in breadth, and sometimes five or six in length, and appear as if they occupied the former channel of some choked-up river, stream, lake, or arm of the sea. The appearance they present to a stranger is singular - a front of tall and perfectly straight trunks, rising to the height of fifty or sixty feet, without a limb, and crowded in every direction, their tops so closely woven together as to shut out the day, spreading the gloom of a perpetual twilight below. On a nearer approach, they are found to rise out of the water, which, from the impregnation of the fallen leaves and roots of the cedars, is of the colour of brandy. Amidst this bottom of congregated springs, the ruins of the former forest lie piled in every state of confusion. The roots, prostrate logs, and, in many places, the water, are covered with green, mantling moss, while an undergrowth of laurel, fifteen or twenty feet high, intersects every opening so completely, as to render a passage through laborious and harassing beyond description; at every step, you either sink to the knees, clamber over fallen timber, squeeze yourself through between the stubborn laurels, or 
plunge to the middle in ponds made by the uprooting of large trees, which the green moss concealed from observation. In calm weather, the silence of death reigns in these dreary regions; a few interrupted rays of light shoot across the gloom; and unless for the occasional hollow screams of the Herons, and the melancholy chirping of one or two species of small birds, all is silence, solitude, and desolation. When a breeze rises, at first it sighs mournfully through the tops; but as the gale increases, the tall mast-like cedars wave like fishing-poles, and rubbing against each other, produce a variety of singular noises, that, with the help of a little imagination, resemble shrieks, groans, growling of bears, wolves, and such like comfortable music.

On the tops of the tallest of these cedars the Herons construct their nests, ten or fifteen pair sometimes occupying a particular part of the swamp. The nests are large, formed of sticks, and lined with smaller twigs; each occupies the top of a single tree. The eggs are generally four, of an oblong, pointed form, larger than those of a hen, and of a light greenish blue, without any spots. The young are produced about the middle of May, and remain on the trees until they are full as heavy as the old ones, being extremely fat, before they are able to fly. They breed but once in the season. If disturbed in their breeding-place, the old birds fly occasionally over the spot, sometimes honking like a goose, sometimes uttering a coarse, hollow, grunting noise, like that of a hog, but much louder. 
The Great Heron is said to be fat at the full moon, and lean at its decrease ; this might be accounted for by the fact of their fishing regularly by moonlight through the greater part of the night, as well as during the day; but the observation is not universal, for at such times $I$ have found some lean, as well as others fat. The young are said to be excellent for the table, and even the old birds, when in good order, and properly cooked, are esteemed by many.

The principal food of the Great Heron is fish, for which he watches with the most unwearied patience, and seizes them with surprising dexterity. At the edge of the river, pond, or sea-shore, he stands fixed and motionless, sometimes for hours together. But his stroke is quick as thought, and sure as fate, to the first luckless fish that approaches within his reach; these he sometimes beats to death, and always swallows head foremost, such being their uniform position in the stomach. He is also an excellent mouser, and of great service to our meadows, in destroying the shorttailed or meadow mouse, so injurious to the banks. He also feeds eagerly on grasshoppers, various winged insects, particularly dragon flies, which he is very expert at striking, and also eats the seeds of that species of nymphre usually called spatterdocks, so abundant along our fresh-water ponds and rivers.

The Heron has great powers of wing, flying sometimes very high, and to a great distance; his neck doubled, his head drawn in, and his long legs stretched out in a right 
line behind him, appearing like a tail, and, probably, serving the same rudder-like office. When he leaves the sea-coast, and traces, on wing, the courses of the creeks or rivers upwards, he is said to prognosticate rain; when downwards, dry weather. $\mathrm{He}$ is most jealously vigilant and watchful of man, so that those who wish to succeed in shooting the Heron, must approach him entirely unseen, and by stratagem. The same inducements, however, for his destruction, do not prevail here as in Europe. Our sea-shores and rivers are free to all for the amusement of fishing. Luxury has not yet constructed her thousands of fish-ponds, and surrounded them with steel traps, spring guns and Heron snares. In our vast fens, meadows, and sea-marshes, this stately bird roams at pleasure, feasting on the never-failing magazines of frogs, fish, seeds, and insects, with which they abound, and of which he, probably, considers himself the sole lord and proprietor. I have several times seen the bald eagle attack and tease the Great Heron; but whether for sport, or to make him disgorge his fish, I am uncertain.

The Common Heron of Europe very much resembles the present, which might, as usual, have probably been ranked as the original stock, of which the present was a mere degenerated species, were it not that the American is greatly superior, in size and weight, to the European species; the former measuring four feet four inches, and weighing upwards of seven pounds; the latter, three feet three inches, and rarely weighing more than four pounds. Yet, with the 


\section{THE GREAT HERON.}

cxception of size, and the rust-coloured thighs of the present, they are extremely alike. The Common Heron of Europe, however, is not an inhabitant of the United States.

The Great Heron does not receive his full plumage during the first season, nor until the summer of the second. In the first season, the young birds are entirely destitute of the white plumage of the crown, and the long, pointed feathers of the back, shoulders, and breast. In this dress I have frequently shot them in autumn; but in the third year, both males and females have assumed their complete dress, and, contrary to all the European accounts which I have met with, both are then so nearly alike in colour and markings, as scarcely to be distinguished from each other, both having the long, flowing crest, and all the ornamental, white, pointed plumage of the back and breast. Indeed, this sameness in the plumage of the males and females, when arrived at their perfect state, is a characteristic of the whole of the genus with which I am acquainted. Whether it be different with those of Europe, or that the young and imperfect birds have been hitherto mistaken for females, I will not pretend to say, though I think the latter conjecture highly probable, as the night raven has been known in Europe for several centuries, and yet, in all their accounts, the sameness of the colours and plumage of the male and female of that bird is nowhere mentioned; on the contrary, the young, or yearling bird, has been universally described as the female. 


\section{ILLUSTRATIVE ANECDOTES.}

"The Heron," says an English writer, "is a very "great devourer of fish, and does more mischief in a pond than an otter. People who have kept Herons, have had the curiosity to number the fish they feed them with into a tub of water, and counting them again afterwards, it has been found that they will eat up fifty moderate dace and roaches in a day. It has been found, that in carp-ponds visited by this bird, one Heron will eat up a thousand store carp in a year; and will hunt them so close, as to let very few escape. The readiest method of destroying this mischievous bird, is by fishing for him in the manner of pike, with a baited hook. When the haunt of the Heron is found out, three or four small roach, or dace, are to be procured, and each of them is to be baited on a wire, with a strong hook at the end, entering the wire just at the gills, and letting it run just under the skin to the tail; the fish will live in this manner for five or six days, which is a very essential thing; for if it be dead, the Heron will not touch it. A strong line is then to be prepared of silk and wire twisted together, and is to be about two yards long; tie this to the wire that holds the hook, and to the other end of it there is to be tied a stone of about a pound weight; let three or four of these baits be sunk in different shallow parts of the pond, and, in a night or two's time, the Heron will not fail to be taken with one or other of them." 


\section{THE WOOD IBIS. (Tantalus loculator.)}

THe Wood Ibis (says Mr. Wilson) inhabits the lower parts of Louisiana, Carolina, and Georgia; is very common in Florida, and extends as far south as Cayenne, Brazil, and various parts of South America. In the United States it is migratory; but has never, to my knowledge, been found to the north of Virginia. Its favourite haunts are watery savannas and inland swamps, where it feeds on fish and reptiles. The French inhabitants of Louisiana esteem it good eating.

With the particular manners of this species I am not personally acquainted; but the following characteristic traits are given of it by. Mr. William Bartram, who had the best opportunities of noting them:

"This solitary bird," he observes, "does not associate in flocks, but is generally seen alone, commonly near the banks of great rivers, in vast marshes or meadows, especially such as are covered by inundations, and also in the vast, deserted rice plantations; he stands alone on the topmost limb of tall, dead cypress-trees, his neck contracted or drawn in upon his shoulders, and his beak resting, like a long scythe, upon his breast; in this pensive posture, and solitary situation, they look extremely grave, sorrowful, and melancholy, as if in the deepest thought. They are never seen on the sea-coast, and yet are never found at a great distance from it. They feed on serpents, young alligators, frogs, and other reptiles." 


\section{THE SNOW GOOSE. (Anas hyperborea.)}

This species, called on the sea-coast the Red Goose, arrives in the river Delaware, from the north, early in November, sometimes in considerable flocks, and is extremely noisy, their notes being shriller and more squeaking than those of the Canada, or Common Wild Goose. On their first arrival they make but a short stay, proceeding, as the depth of winter approaches, farther to the south; but from the middle of February, until the breaking up of the ice in March, they are frequently numerous along both shores of the Delaware, about and below Reedy Island, particularly near Old Duck Creek, in the state of Delaware. They feed on the roots of the reeds there, tearing them up from the marshes like hogs. Their flesh, like most others of their tribe, that feed on vegetables, is excellent.

The Snow Groose is two feet eight inches in length, and five feet in extent; the bill is three inches in length, remarkably thick at the base, and rising high in the forehead, but becomes small and compressed at the extremity, where each mandible is furnished with a whitish rounding nail; the colour of the bill is a purplish carmine; the edges of the two mandibles separate from each other, in a singular manner, for their whole length, and this gibbosity is occupied by dentated rows, resembling teeth, these, and the parts adjoining, being of a blackish colour; the whole plumage is of a snowy whiteness, with the exception, first, 
of the fore part of the head all round as far as the eyes, which is of a yellowish rust-colour, intermixed with white; and, second, the nine exterior quill-feathers, which are black, shafted with white, and white at the root; the covers of these last, and also the bastard wing, are sometimes of a pale ash-colour; the legs and feet, of the same purplish carmine as the bill; iris, dark hazel; the tail is rounded and consists of sixteen feathers ; that, and the wings, when shut, nearly of a length.

The bill of this bird is singularly curious; the edges of the upper and lower gibbosities have each twenty-three indentations, or strong teeth, on each side; the inside, or concavity of the upper mandible, has also seven lateral rows of strong, projecting teeth ; and the tongue, which is horny at the extremity, is armed on each side with thirteen long and sharp, bony teeth, placed like those of a saw, with their points directed backwards; the tongue turned up, and viewed on its lower side, looks very much like a human finger with its nail. This conformation of the mandibles, exposing two rows of strong teeth, has, probably, given rise to the epithet Laughing, bestowed on one of its varieties, though it might, with as much propriety, have been named the Grinning Goose.

The specimen from which the above description was taken, was shot on the Delaware, below Philadelphia, on the 15th of February, and on dissection proved to be a male; the windpipe had no labyrinth, but, for an inch or two 
before its divarication into the lungs, was inflexible, not extensile, like the rest, and rather wider in diameter. The gullet had an expansion before entering the stomach, which last was remarkably strong, the two great grinding muscles being nearly five inches in diameter. The stomach was filled with fragments of the roots of reeds, and fine sand. The intestines measured eight feet in length, and were not remarkably thick. The liver was small.

\section{ILLUSTRATIVE ANECDOTES.}

Latham observes that this species is very numerous at Hudson's Bay, that they visit Severn river in May, and stay a fortnight, but go farther north to breed; they return to Severn Fort the beginning of September, and stay till the middle of October, when they depart for the south, and are observed to be attended by their young, in flocks innumerable. They seem to occupy also the western side of America, as they were seen at Aoonalashka, as well as Kamtschatka. White Brant, with black tips to their wings, were also shot by Captains Lewis and Clark's exploring party, near the mouth of the Columbia river, which were probably the same as the present species. Mr. Pennant says, "They are taken by the Siberians in nets, under which they are decoyed by a person covered with a white skin, and crawling on all fours; when, others driving them, these stupid birds, mistaking him for their leader, follow him, when they are entangled in the nets, or led into a kind of pond made for the pur- 
pose!" We might here, with propriety, add-This wants confirmation.

\section{THE WANDERING ALBATROSS. (Diomedea exulans.)}

THIs bird is found in the Atlantic Ocean, from Southern Africa to the American coast, as well as in the Pacific. There are three species of the genus, viz: the Albatross of China; the Yellow and Black-beaked Albatross, and the Common or Wandering Albatross.

The Common Albatross is the species which is most frequently met with in the seas of Southern Africa. It is the largest sea-bird known. On account of its size and colour it is often called the Sheep of the Cape,-a name under which it is found in several voyages. The top of the head is a ruddy gray; the rest of the plumage is white, with the exception of several transverse black bands on the back, and a few of the wing-feathers. The feet and membrane are of a deep flesh-colour; the bill a pale yellow.

The weight of this bird has been variously stated, at from twelve to twenty-eight pounds; and a similar difference appears to exist in authors, with respect to the distance between the extremity of the extended wings. Forster says about ten feet,-Parkins, eleven feet seven inches,-Cook, eleven feet; another says twelve feet; a specimen in the 


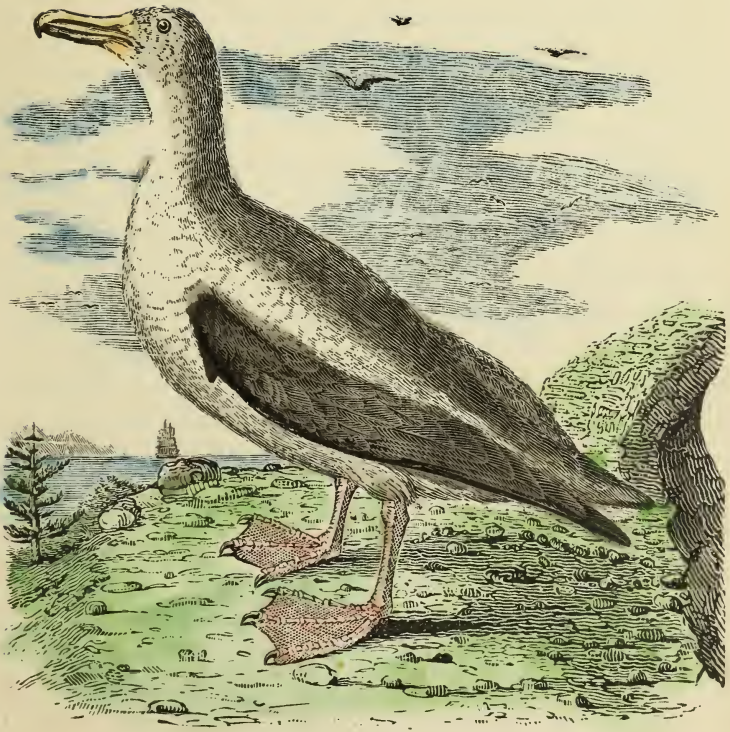



Leverian museum measured thirteen feet; and Ives (p. 5), mentions one, shot off the Cape of Good Hope, which measured seventeen feet and a half from wing to wing. Dr. Arnott, in his Physies, says,- " How powerful must be the wing-muscles of birds, which sustain themselves in the sky for hours together! The Great Albatross, with wings extending fourteen feet or more, is seen in the stormy solitude of the Southern Ocean, accompanying ships for whole days without ever resting on the waves!"

We can, from this circumstance, readily understand the extensive range in which the Albatross is found; not being confined, as Buffon imagined, to the Southern Ocean, but being equally abundant in the northern latitudes, though Forster says, he never observed it within the tropics. These birds are seen in immense flocks about Behring's Straits and Kamtschatka, about the end of June, frequenting chiefly the inner sea, the Kurile Islands, and the Bay of Pentschinensi, whereas scarcely a straggler is to be seen on the eastern or American shore. They seem to be attracted thither by vast shoals of fish, whose migratory movements the albatrosses follow. On their first appearing in those seas, they are very lean, but, from finding abundance of food, they soon become fat. Their voracity is so great, that they will often swallow a salmon of four or five pounds weight, and then, being half choked, and unable, in consequence, to move, the natives easily knock them down with a stick. 
They do not, however, confine themselves to fish, but will prey on any other sea-animal; and Cook's sailors caught them with a line and a hook. The Kamtschadales take them by fastening a cord to a large hook, baited with a whole fish, which the birds greedily seize. Their usual food, however, seems rather to be fish-spawn and small molluscæ. M. Querhoent never found in their stomachs anything besides a thick mucilage.

Notwithstanding their strength, they never venture to attack other sea-birds, but are, on the contrary, attacked by the gulls. "Several large grey gulls," says Cook, "that were pursuing a white albatross, afforded us a diverting spectacle; they overtook it, notwithstanding the length of its wings, and they tried to attack it under the belly, that part being probably defenceless; the albatross had now no means of escaping, but by dipping its body into the water; its formidable bill seemed to repel them."

Their flesh is tough and dry; but the Kamtschadales take them for the sake of their entrails, which they blow and use as buoys for their nets. They employ the wingbones also, which Edwards says are as long as their whole body, for tobacco pipes. 


\section{THE SWAN. (Anas Cygnus.)}

So much difference is there between this bird when on land and in the water, that it is hardly to be supposed the same; for in the latter, no bird can possibly exceed it for beauty and majestic appearance. When it ascends from its favourite element, its motions are awkward, and its neck is stretched forward with an air of stupidity; it has, indeed, the air of being only a larger sort of goose; but when seen smoothly gliding along the water, displaying a thousand graceful attitudes, and moving at pleasure without the smallest apparent effort, there is not a more beautiful figure in all nature. In its form, we find no broken or harsh lines; in its motions, nothing constrained or abrupt; but the roundest contours, and the easiest transitions; the eye wanders over the whole with unalloyed pleasure, and with every change of position every part assumes a new grace. It will swim faster than a man can walk.

This bird has long been rendered domestic; and it is now a doubt whether there be any of the tame kind in a state of nature. The colour of the tame Swan is entirely white, and it generally weighs full twenty pounds. Under the feathers is a very thick soft down, which is made an article of commerce, for purposes of both use and ornament. The windpipe sinks down into the lungs in the ordinary manner ; and it is the most silent of all the feathered tribes; it can do nothing more than hiss, which it does on receiving 
any provocation. In these respects it is very different from the wild or Whistling Swan.

This beautiful bird is as delicate in its appetites as it is elegant in its form. Its chief food is corn, bread, herbs growing in the water, and roots and seeds, which are found near the margin. At the time of incubation it prepares a nest in some retired part of the bank, and chiefly where there is an inlet in the stream. This is composed of water plants, long grass, and sticks: and the male and female assist in forming it with great assiduity. The Swan lays seven or eight eggs, white, one every other day, much larger than those of a goose, with a hard, and sometimes a tuberous shell. It sits six weeks before its young are excluded; which are ash-coloured when they first leave the shell, and for some months after. It is not a little dangerous to approach the old ones, when their little family are feeding round them. Their fears, as well as their pride, seem to take the alarm, and when in danger, the old birds carry off the young ones on their back. A female has been known to attack and drown a fox, which was swimming towards her nest; they are able to throw down and trample on youths of fifteen or sixtecn; and an old Swan can break the leg of a man with a single stroke of its wing. 


\section{THE CINEREOUS COOT. (Fulica Americana.)}

THIs species makes its appearance in Pennsylvania about the first of October. Among the muddy flats and islands of the river Delaware, which are periodically overflowed, and which are overgrown with the reed, or wild oats, and rushes, the Coots are found. They are not numerous, and are seldom seen, except their places of resort be covered with water ; in that case they are generally found sitting on the fallen reed, waiting for the ebbing of the tide, which will enable them to feed. Their food consists of various aquatic plants, seeds, insects, and, it is said, small fish.

The Coot has an aversion to take wing, and can seldom be sprung in its retreat at low water; for, although it walks rather awkwardly, yet it contrives to skulk through the grass and reeais with great speed, the compressed form of its body, like that of the rail genus, being well adapted to the purpose. It swims remarkably well, and, when wounded, will dive like a duck. When closely pursued in the water, it generally takes to the shore, rising with apparent reluctance, like a wounded duck, and fluttering along the surface, with its feet pattering on the water. It is known in Pennsylvania by the name of the Mud-Hen.

I have never yet discovered that this species breeds with us (says Wilson), though it is highly probable that some few may occupy the marshes of the interior, in the vicinity of the ponds and lakes, for this purpose ; those retired situ- 
ations being well adapted to the hatching and rearing of their young. In the Southern States, particularly South Carolina, they are well known; but the Floridas appear to be their principal rendezvous for the business of incubation. "The Coot," says William Bartram, "is a native of North America, from Pennsylvania to Florida. They inhabit large rivers, fresh-water inlets or bays, lagoons, \&c., where they swim and feed amongst the reeds and grass of the shores; particularly in the river St. Juan, in East Florida ; where they are found in immense flocks. They are loquacious and noisy, talking to one another night and day; are constantly on the water, the broad, lobated membranes on their toes enabling them to swim and dive like ducks."

The Coot inhabits the shores of Sweden and Norway; appears in the spring, and very rarely visits the lakes or moors. Is found in Russia, China, Persia, Greenland, and Siberia. It is common in France, particularly in Lorraine.

"This species is met with in Great Britain, at all seasons of the year; and it is generally believed, that it does not migrate to other countries, but changes its stations, and removes in the autumn from the lesser pools, or loughs, where the young have been reared, to the larger lakes, where flocks assemble in the winter. The female commonly builds her nest in a bunch of rushes, surrounded by the water; it is composed of a great quantity of coarse dried weeds, well matted together, and lined within with softer and finer grasses; she lays from twelve to fifteen eggs at a 
time, and commonly hatches twice in a season; her eggs are about the size of those of a pullet, and are of a pale brownish white colour, sprinkled with numerous small, dark, spots, which at the thicker end, seem as if they had run into each other, and formed bigger blotches.

"As soon as the young quit the shell, they plunge into the water, dive, and swim about with great ease; but they still gather together about the mother, and take shelter under her wings, and do not entirely leave her for some time. They are at first covered with sooty coloured down, and are of a shapeless appearance; while they are in this state, and before they have learned by experience to shun danger, the kite, moor buzzard, and others of the hawk tribe, make dreadful havoc among them."

The Cinereous Coot is sixteen inches in length, and twenty-eight in extent; bill, one inch and a half long, white, the upper mandible slightly notched near the tip, and marked across with a band of chestnut, the lower mandible marked on each side with a squarish spot of the like colour, edged on the lower part with bright yellow, or gamboge, thence to the tip, pale horn colour; membrane of the forehead, dark chestnut brown; irides, cornelian red; beneath the eye, in most specimens, a whitish spot; the head and neck are of a deep shining black, resembling satin; back and scapulars, dirty greenish olive; shoulders, breast, and wing-coverts, slate blue; the under parts are hoary; vent black; beneath the tail, pure white; primaries 
and secondaries, slate, the former tipped with black, the latter with white, which does not appear when the wing is closed; outer edges of the wings, white; legs and toes yellowish green, the scalloped membrane of the latter, lead colour; middle toe, including the claw, three inches and three-auarters long.

\section{ILLUSTRATIVE ANECDOTES.}

Buffon describes the mode of shooting Coots in France, particularly in Lorraine, on the great pools of Tiaucourt, and of Indre; hence we are led to suppose, that they are esteemed as an article of food. But with us, who are enabled, by the abundance and variety of game, to indulge in greater luxuries in that season when our Coots visit us, they are considered as of no account, and are seldom eaten.

The European ornithologists represent the membrane on the forehead of the Coot as white, except in the breeding season, when it is said to change its colour to pale red. This circumstance would induce one to suppose, that our Coot is a different species from the European, which I have never had the satisfaction to behold; and, indeed, I am much of that opinion.

It is a very rare occurrence, that the Coot is seen in the vicinity of Philadelphia in the spring or summer. The 19th of March, 1814, I had the satisfaction of being presented with one, a female, which was shot in the Schuylkill, at Gray's Ferry. I could see no difference in its plumage 
and markings, from those of the full-grown male, except the head and neck not being of so deep a black. The membrane on the forehead was not more than half the size of that of the female specimen, described above, and it was of the same colour, viz., dark chestnut. All the birds which I have ever seen, had this appendage of the same colour.

In Lewis and Clark's history of their expedition, mention is made of a bird which is common on the Columbia; is said to be very noisy, to have a sharp, shrill whistle, and to associate in large flocks; it is called the Black Duck. This is doubtless a species of Coot, but whether or not different from ours, cannot be ascertained. How much is it to be regretted, that, in an expedition of discovery, planned and fitted out by an enlightened government, furnished with every means for safety, subsistence, and research, not one naturalist, not one draughtsman, should have been sent, to observe and perpetuate the infinite variety of natural productions, many of which are entirely unknown to the community of science, which that extensive tour must have revealed!

\section{THE SUMMER, or WOOD DUCK. (Anas sponsa.)}

THIs most beautiful of Ducks (says Nuttall) seems to be dressed in a studied attire, to which the addition of a flow- 
ing crest adds a finish of peculiar elegance; and hence Linnæus has dignified the species with the title of Sponsa, or the Bride. This splendid bird is peculiar to America, but extends its residence from the cold regions of Hudson's Bay, in the 54th parallel, to Mexico and the Antilles. Throughout a great part of this vast space, or at least as far south as Florida and the Mississippi territory, the Summer Duck is known to breed. In the interior they are also found in the state of Missouri, and along the woody borders and still streams which flow into most of the great northwestern lakes of the St. Lawrence. The Summer Duck, so called from its constant residence in the United States, has indeed but little predilection for the sea-coast, its favourite haunts being the solitary, deep, and still waters, ponds, woody lakes, and the mill-dams in the interior, making its nest often in decayed and hollow trees impending over the water.

Though many migrate probably to the shores of the Mexican Gulf, numbers pass the winter in the states south of Virginia. Early in February they are seen associated by pairs on the inundated banks of the Alabama, and are frequent at the same season in the waters of West Florida. In Pennsylvania they usually nest late in April or early in May, choosing the hollow of some broken or decayed tree, and sometimes even constructing a rude nest of sticks in the forks of branches. The eggs, twelve or thirteen, are yellowish-white, rather less than those of the domestic hen, and 
they are usually covered with down, probably plucked from the breast of the parent. The same tree is sometimes occupied, by the same pair, for several successive years, in the breeding season. The young, when hatched, are carried down in the bill of the female, and afterwards conducted by her to the nearest water. To these places, when once selected, if not disturbed, they sometimes show a strong predilection, and are not easily induced to forsake the premises, however invaded by noise and bustle. While the female is sitting, the male is usually perched on some adjoining limb of the same tree, keeping watch for their common safety. The species is scarcely ever gregarious, they are only seen in pairs or by families. The common note of the drake is peet, peet; but when on his post as sentinel, on espying danger, he makes a sort of crowing noise, like 'hoo eek, 'hoo eek.

The food of the Wood Duck consists principally of acorns, the seeds of aquatic plants, such as the Wild Oat, Ruppia, \&c., and insects, which inhabit in or near waters; and I have seen a fine male whose stomach was wholly filled with a mass of the small coleoptera, called Donatias, which are seen so nimbly flying over or resting on the leaves of the pond lily; they are therefore very alert in quest of their prey, or they could never capture these wary insects. They are not uncommon in the markets of the Eastern and Middle States, and are justly esteemed as food.

The Wood Duck has sometimes been tamed, and soon 


\section{THE S UMMER D U CK.}

becomes familiar. They have even been so far domesticated as to run about at large in the barn-yard like ordinary fowls. In France they have also been acclimated and tamed, and have bred in this condition.

\section{ILLUSTRATIVE ANE,CDOTES.}

The Summer Duck is equally well known in Mexico and many of the West India islands. During the whole of our winters, they are occasionally seen in the states south of the Potomac. On the 10th of January (says Wilson), I met with two on a creek near Petersburgh, in Virginia. In the more northern districts, however, they are migratory. In Pennsylvania, the female usually begins to lay late in April or early in May. Instances have been known where the nest was constructed of a few sticks laid in a fork of the branches; usually, however, the inside of a hollow tree is selected for this purpose.

On the 18th of May I visited a tree containing the nest of a Summer Duck, on the banks of Tuckahoe river, New Jersey. It was an old, grotesque white oak, whose top had been torn off by a storm. It stood on the declivity of the bank, about twenty yards from the water. In this hollow and broken top, and about six feet down, on the soft, decayed wood, lay thirteen eggs, snugly covered with down, doubtless taken from the breast of the bird. These eggs were of an exact oval shape, less than those of a hen, the surface exceedingly fine grained, and of the highest polish, 
and slightly yellowish, greatly resembling old, polished ivory. The egg measured two inches and an eighth by one inch and a half. On breaking one of them, the young bird was found to be nearly hatched, but dead, as neither of the parents had been observed about the tree during the three or four days preceding, and were conjectured to have been shot.

This tree had been occupied, probably by the same pair, for four successive years, in breeding time; the person who gave me the information, and whose house was within twenty or thirty yards of the tree, said that he had seen the female, the spring preceding, carry down thirteen young, one by one, in less than ten minutes. She caught them in her bill by the wing or back of the neck, and landed them safely at the foot of the tree, whence she afterwards led them to the water.

Under this same tree, at the time I visited it, a large sloop lay on the stocks, nearly finished; the deck was not more than twelve feet distant from the nest, yet notwithstanding the presence and noise of the workmen, the Ducks would not abandon their old breeding place, but continued to pass out and in, as if no person had been near. The male usually perched on an adjoining limb, and kept watch while the female was laying, and also often while she was sitting. A tame goose had chosen a hollow space at the root of the same tree, to lay and hatch her young in. 
The Summer Duck seldom flies in flocks of more than three or four individuals together, and most commonly in pairs, or singly. Their flesh is inferior to that of the bluewinged teal. They are frequent in the markets of Philadelphia.

Among other gaudy feathers with which the Indians ornament the calumet or pipe of peace, the skin of the head and neck of the Summer Duck is frequently seen covering the stem.

This beautiful bird has often been tamed, and soon becomes so familiar as to permit one to stroke its back with the hand. I have seen individuals so tamed, in various parts of the Union. Captain Boyer, collector of the port of Havre-de-Grace, informs me, that, about forty years ago, a Mr. Nathan Nicols, who lived on the west side of Gunpowder Creek, had a whole yard swarming with Summer Ducks, which he had tamed and completely domesticated, so that they bred and were as familiar as any other tame fowls; that he (Captain Boyer) himself saw them in that state, but does not know what became of them. Latham says, that they are often kept in European menageries, and will breed there. 


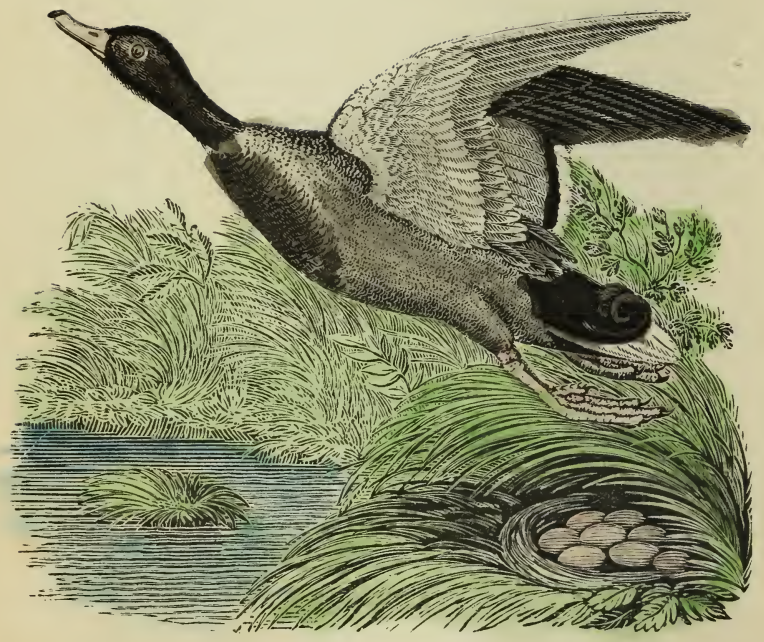




\section{THE COMMON DUCK, or MALLARD. (Anas domestica.)}

THe Mallard, or original of our domestic Duck, like so many other species (says Mr. Nuttall) is common to most parts of the northern hemisphere. As a bird of passage, in spring and autumn, it is seen in every part of the United States, and indeed inhabits more or less the whole continent, from the Gulf of Mexico to the 68th parallel in the fur countries of the Canadian wilderness. In Europe it is met with everywhere, up to the dreary climates of Greenland, where many even pass the greater part of the winter. They breed in the inland woody districts of the fur countries, and more or less through all the intermediate space as far south as Pennsylvania. In England also, as well as in Sweden, Denmark, Germany, and all parts of the vast dominions of Russia, no less than Arctic Europe, and the Aleutian Islands in the north Pacific, the Wild Duck is known to breed. They nest commonly on the borders of rivers and lakes, sometimes at a considerable distance from water, amongst reeds, grass, or in fields and copses, according to the convenience of the locality, and occasionally even upon trees impending over waters. For its nest it scrapes together a small quantity of such dry weeds as happen to be contiguous, and lays from ten to eighteen eggs of a bluish-white. At the time of incubation, the female plucks 
the down from her breast to line the nest, and frequently covers the eggs when she leaves them.

\section{ILLUSTRATIVE ANECDOTES.}

The Duck, like other birds whose young ones run as soon as they are hatched, generally deposits her eggs on the ground; but there are some exceptions to this rule. Mr. Selby says: "Such an instance once occurred within my knowledge, and near my own residence, where a Wild Duck laid her eggs in the old nest of a crow, at least thirty feet from the ground. At this elevation she hatehed her young; and as none of them were found dead beneath the tree, it is presumed she carried them safely to the ground in her bill, a mode of conveyance known to be frequently adopted by the Eider Duck." Montagu says, "We have been assured by a person of undoubted veracity that a half domesticated Duck made a nest in Rumford Tower, hatched her young, and brought them down in safety to a piece of water at a considerable distance. Others have been known to breed in trees; and we recollect the nest of this bird being found in the head of an ald pollard willow, impending the water, from whence the young might readily drop unhurt into their natural element. Mr. Tunstall mentions one, at Etchingham, in Sussex, which was found sitting upon nine eggs, on an oak-tree, twenty-five feet from the ground: and the author of the 'Rural Sports' records an instance of one taking possession of the nest of a hawk in a large oak. To 
these we can add, upon the testimony of a gentleman of the strictest veracity, that out of a large flock of half-domesticated Ducks, one deposited her eggs in the principal fork of a large tree near his house. Eggs, ten to fourteen, of a bluish-white; the female, when she quits the nest for food, covers them with down and other substances.

\section{'IHE CANVASS-BACK DUCK. (Anas valisineria.)}

THIs celebrated American species (says Mr. Wilson), as far as can be judged from the best figures and descriptions of foreign birds, is altogether unknown in Europe. It approaches nearest to the pochard of England, but differs from that bird in being superior in size and weight, in the greater magnitude of its bill, and the general whiteness of its plumage. A short comparison of the two will elucidate this point: The Canvass-Back measures two feet in length by three feet in extent, and, when in the best order, weighs three pounds and upwards. The pochard, according to Latham and Bewick, measures nineteen inches in length, and thirty in extent, and weighs one pound twelve or thirteen ounces. The latter writer says of the pochard, "The plumage, above and below, is wholly covered with prettilyfreckled, slender, dusky threads, disposed transversely in 


\section{THE CAN VASS-B A C K D U C .}

close-set, zigzag lines, on a pale ground, more or less shaded off with ash," - a description much more applicable to the red-head, which, very probably, is the species meant.

In the figure of the pochard given by Mr. Bewick, who is generally correct, the bill agrees very well with that of our red-head; but is scarcely half the size and thickness of that of the Canvass-Back; and the figure in the Planches Enluminées corresponds, in that respect, with Bewick's. In short, either these writers are egregiously erroneous in their figures and descriptions, or the present Duck was altogether unknown to them. Considering the latter supposition the more probable of the two, I have designated this as a new species, and shall proceed to detail some particulars of its history.

The Canvass-Back Duck arrives in the United States from the north about the middle of October; a few descend to the Hudson and Delaware, but the great body of these birds resort to the numerous rivers belonging to and in the neighbourhood of the Chesapeake Bay, particularly the Susquehanna, the Patapsco, Potomac, and James rivers, which appear to be their general winter rendezvous. Beyond this, to the south, I can find no certain accounts of them. At the Susquehanna, they are called Canvass-Backs; on the Potomac, White-Backs; and on James river, Sheldrakes. They are seldom found at a great distance up any of these rivers, or even in the salt-water bay; but in that particular part of tide water where a certain grass-like plant 
grows, on the roots of which they feed. This plant, which is said to be a species of valisineria, grows on fresh-water shoals of from seven to nine feet (but never where these are occasionally dry), in long, narrow, grass-like blades, of four or five feet in length; the root is white, and has some resemblance to small celery. This grass is in many places so thick that a boat can with difficulty be rowed through it, it so impedes the oars. The shores are lined with large quantities of it, torn up by the Ducks, and drifted up by the winds, lying, like hay, in windrows.

Wherever this plant grows in abundance, the CanvassBacks may be expected, either to pay occasional visits, or to make it their regular residence during the winter. It occurs in some parts of the Hudson; in the Delaware, near Gloucester, a few miles below Philadelphia; and in most of the rivers that fall into the Chesapeake, to each of which particular places these Ducks resort; while, in waters unprovided with this nutritive plant, they are altogether unknown.

On the first arrival of these birds in the Susquehanna, near Havre-de-Grace, they are generally lean; but such is the abundance of their favourite food that, towards the beginning of November, they are in pretty good order. They are excellent divers, and swim with great speed and agility. They sometimes assemble in such multitudes as to cover several acres of the river, and when they rise suddenly, produce a noise resembling thunder. They float 
about these shoals, diving, and tearing up the grass by the roots, which is the only part they eat. They are extremely shy, and can rarely be approached, unless by stratagem. When wounded in the wing, they dive to such prodigious distances, and with such rapidity, continuing it so perseveringly, and with such cunning and active vigour, as almost always to render the pursuit hopeless.

From the great demand for these Ducks, and the high price they uniformly bring in market, various modes are practised to get within gunshot of them. The most successful way is said to be decoying them to the shore by means of a dog, while the gunner lies closely concealed in a proper situation. The dog, if properly trained, plays backwards and forwards along the margin of the water; and the Ducks, observing his manœuvres, enticed perhaps by curiosity, gradually approach the shore, until they are sometimes within twenty or thirty yards of the spot where the gunner lies concealed, and from which he rakes them, first on the water, and then as they rise. This method is called tolling them in. If the Ducks seem difficult to decoy, any glaring object, such as a red handkerchief, is fixed round the dog's middle, or to his tail; and this rarely fails to attract them. Sometimes, by moonlight, the sportsman directs his skiff towards a flock whose position he had previously ascertained, keeping within the projecting shadow of some wood, bank, or headland, and paddles along so silently and imperceptibly as often to approach within fifteen 
or twenty yards of a flock of many thousands, among whom he generally makes great slaughter.

Many other stratagems are practised, and, indeed, every plan that the ingenuity of the experienced sportsman can suggest, to approach within gunshot of these birds; but, of all the modes pursued, none intimidate them so much as shooting them by night; and they soon abandon the place where they have been thus repeatedly shot at. During the day, they are dispersed about; but towards evening, collect in large flocks, and come into the mouths of creeks, where they often ride as at anchor, with their head under their wing, asleep, there being always sentinels awake, ready to raise an alarm on the least appearance of danger. Even when feeding and diving in small parties, the whole never go down at one time, but some are still left above on the look-out.

When the winter sets in severely, and the river is frozen, the Canvass-Backs retreat to its confluence with the bay, occasionally frequenting air-holes in the ice, which are sometimes made for the purpose, immediately above their farourite grass, to entice them within gunshot of the hut or bush which is usually fixed at a proper distance, and where the gunner lies concealed, ready to take advantage of their distress.

A Mr. Hill, who lives near James river, at a place called Herring Creek, informs me, that, one severe winter, he and another person broke a hole in the ice, about twenty by 
144 THE CAN V A S -B A C K UCK.

forty feet, immediately over a shoal of grass, and took their stand on the shore in a hut of brush, each having three guns well loaded with large shot. The Ducks, which were flying up and down the river, in great extremity, soon crowded to this place, so that the whole open space was not only covered with them, but vast numbers stood on the ice around it. They had three rounds, firing both at once, and picked up eighty-eight Canvass-Backs, and might have collected more, had they been able to get to the extremity of the ice after the wounded ones.

In the severe winter of $1779-80$, the grass, on the roots of which these birds feed, was almost wholly destroyed in James river. In the month of January, the wind continued to blow from W. N. W. for twenty-one days, which caused such low tides in the river, that the grass froze to the ice everywhere; and, a thaw coming on suddenly, the whole was raised by the roots, and carried off by the freshet. The next winter, a few of these Ducks were seen, but they soon went away again; and, for many years after, they continued to be scarce; and, even to the present day, in the opinion of my informant, have never been so plenty as before.

The Canvass-Back, in the rich juicy tenderness of its flesh, and its delicacy of flavour, stands unrivalled by the whole of its tribe in this or perhaps in any other quarter of the world. Those killed in the waters of the Chesapeake are generally esteemed superior to all others doubtless from the great abundance of their favourite food which these 
rivers produce. At our public dinners, hotels, and particular entertainments, the Canvass-Backs are universal favourites. They not only grace but dignify the table, and their very name conveys to the imagination of the eager epicure the most comfortable and exhilarating ideas. Hence, on such occasions, it has not been uncommon to pay from one to three dollars a pair for these Ducks; and, indeed, at such times, if they can, they must be had, whatever may be the price.

The Canvass-Back will feed readily on grain, especially wheat, and may be decoyed to particular places by baiting them with that grain for several successive days. Some few years since, a vessel loaded with wheat was wrecked near the entrance of Great Egg Harbor, in the autumn, and went to pieces. The wheat floated out in vast quantities, and the whole surface of the bay was in a few days covered with Ducks of a kind altogether unknown to the people of that quarter. The gunners of the neighbourhood collected in boats, in every direction, shooting them; and so successful were they, that, as Mr. Beaseley informs me, two hundred and forty were killed in one day, and sold among the neighbours, at twelve and a half cents apiece, without the feathers. The wounded ones were generally abandoned, as being too difficult to be come up with. They continued about for three weeks, and during the greater part of that time a continual cannonading was heard from every quarter. The gunners called then Sea Ducks. They were all Canvass-Backs, at 
that time on their way from the north, when this floating feast attracted their attention, and for a while arrested them in their course. A pair of these very Ducks I myself bought in Philadelphia market at the time, from an Egg Harbor gunner, and never met with their superior, either in weight or excellence of flesh. When it was known among those people the loss they had sustained in selling for twenty-five cents what would have brought them from a dollar to a dollar and a half per pair, universal surprise and regret were naturally enough excited.

The Canvass-Back is two feet long, and three feet in extent, and, when in good order, weighs three pounds; the bill is large, rising high in the head, three inches in length, and one inch and three-eighths thick at the base, of a glossy black; eye, very small; irides, dark red; cheeks and fore part of the head, blackish-brown; rest of the head and greater part of the neck, bright glossy reddish chestnut, ending in a broad space of black that covers the upper part of the breast, and spreads round to the back; back, scapulars, and tertials, white, faintly marked with an infinite number $;$ of transverse, waving lines or points, as if done with a pencil; whole lower parts of the breast, also the belly, white, slightly pencilled in the same manner, scarcely perceptible on the breast, pretty thick towards the vent; wing-coverts, gray, with numerous specks of blackish; primaries and secondaries, pale slate, two or three of the latter of which nearest the body are finely edged with deep velvety black, 
the former dusky at the tips; tail, very short, pointed, consisting of fourteen feathers of a hoary brown; vent and tailcoverts, black; lining of the wing, white; legs and feet, very pale ash, the latter three inches in width - a circumstance which partly accounts for its great powers of swimming.

The female is somewhat less than the male, and weighs two pounds and three-quarters; the crown is blackishbrown; cheeks and throat, of a pale drab; neck, dull brown; breast, as far as the black extends on the male, dull brown, skirted in places with pale drab; back, dusky white, crossed with fine waving lines; belly, of the same dull white, pencilled like the back; wings, feet, and bill, as in the male; tail-coverts, dusky; vent, white, waved with brown.

The windpipe of the male has a large, flattish, concave labyrinth, the ridge of which is covered with a thin, transparent membrane; where the trachea enters this, it is very narrow, but immediately above swells to three times that diameter. The intestines are wide, and measure five feet in length. 


\section{THE PELICAN. (Pelecanus onocrotalus.)}

The White or Great Pelican, or Pelecan, resembles the swan in shape and colour, but exceeds it in size. The singularity, however, which distinguishes it from all other birds, is in the bill and the great pouch underneath, which merit a particular description.

The bill of this bird is about sixteen inches long, from the point to the opening of the mouth, which is a good way behind the eyes. It is very thick at the base, where it is of a greenish tint, but tapers off towards the end, which curves downward, and is of a reddish blue. At the lower edge of the under chap hangs a pouch, capable of containing fifteen quarts of water, and reaching the whole length of the bill to the neck: this bag is covered with a very soft and smooth down, and, when empty, is scarcely perceptible; as the bird has the power of wrinkling it up into the-lower jaw. This bird was formerly known in Europe, particularly in Russia ; but at present it is only found in Africa and America.

The Pelican has strong wings, furnished with thick plumage of an ash-colour, as are the rest of the feathers over the whole body. The large legs are lead-coloured, and the claws gray. The number of toes is four, and these are all webbed together. The eyes are very small, when compared with the size of the head, and there is something in the countenance very sad and melancholy. 


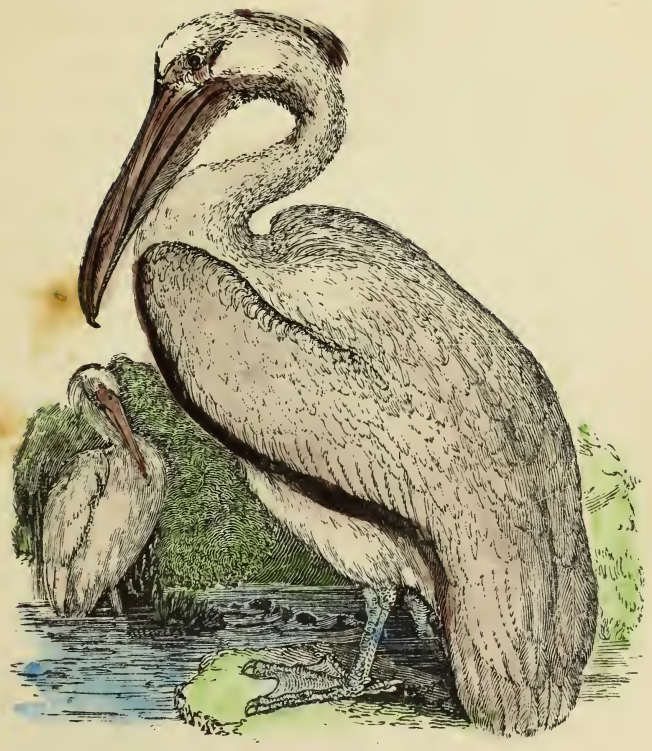



These birds are torpid and inactive to the last degree, so that nothing can exceed their indolence but their gluttony; for were they not excited to labour by the stimulus of hunger, they would always continue in fixed repose. They will often sit for whole days and nights on rocks and branches of trees, motionless, and in a melancholy posture, till the cravings of the stomach compel them to seek for food. When they have raised themselves about thirty or forty feet above the surface of the sea, they turn their head with one eye downward, and continue to fly in that posture. As soon as they perceive a fish sufficiently near the surface, they dart down with the swiftness of an arrow, seize it with unerring certainty, and store it up in their pouch: they then rise again, and continue hovering and fishing, till their bag is filled; when they retire to land, and greedily devour the fruits of their industry. They then sink to sleep, and remain inert till again obliged to provide for their subsistence.

The same habits of indolence seem to attend the Pelican in every situation; for the female does not prepare for the duties of incubation, but drops her eggs on the bare ground, to the number of five or six, and there contrives to hatch them. It is a mere poetical fiction that the Pelican feeds her young with blood from her own breast. Her little progeny, however, seem to call forth some maternal affections; for its young have been taken and tied by the leg to 
a post, and the parent bird has been observed for several days to come and feed them; remaining with them the greatest part of the day, and spending the night on the branch of a tree that hung over them. By these means they became so familiar that they suffered themselves to be handled; and they very readily accepted whatever fish was given to them. These they always put first into their pouch, and then swallowed them at leisure.

Notwithstanding their natural indolence and stupidity, these birds appear to be susceptible of instruction in a domestic state. Some of them have been known to go off at the word of command, and return to their owners with their pouches distended with plunder.

It is said that, when the Pelican and the cormorant fish in company, they adopt a singular mode of catching their prey. They form a large circle, at some distance from the land, and, while the Pelicans flap their wings above, the cormorants dive beneath. The fish are thus driven before the birds, who lessen the circle as they approach the land, and thus enclose their finny spoil within a narrow space, so as to have no difficulty in seizing on a sufficient number. 


\section{THE CORMORANT. (Phalacrocorax carbo.)}

THe Cormorant, or Corvorant, weighs about seven pounds, and is nearly the same size as a goose. The head and neck are of a sooty blackness, and the body is thick and heavy, more inclining in figure to that of the goose than the gull. Its distinguished character, however, consists in its toes being united by membranes, and by the middle toe being notched, like a saw, to assist it in holding its fishy prey.

On the approach of winter, these birds are seen dispersed along the sea-shore, and ascending the mouths of rivers, carrying destruction to all the finny tribe, as they are remarkably voracious, and have such a quick digestion that their appetite appears completely insatiable. Their intestines being thronged with small worms may, perhaps, contribute to their insatiable craving for food. They build their nests on the highest parts of the cliffs that overhang the sea; and the female usually lays three or four eggs about the size of those of the goose, and of a pale green colour.

In China these birds are bred up tame, for the purposes of fishing, and one man can easily manage a hundred of them. When a fisherman intends to fish, he carries them out into the lake, perched on the gunnel of his boat, where they continue tranquil, and expect his orders with patience. When arrived at the proper place, each flies a different way, on a given signal, to fulfil the task assigned it: and it is very pleasant on this occasion to behold with what 
sagacity they portion out the lake or canal where they are upon duty. They hunt about, they plunge, they rise a hundred times to the surface, until they have at last found their prey. They then seize it with their beak by the middle, and carry it to their master. When weary they are suffered to rest for a while, but they are never fed till their work is over. In this manner they supply a very plentiful table; but still their natural voracity cannot be restrained even by education. While they fish, they have always a string fastened round their throats, to prevent them from devouring their prey; as otherwise they would soon satiate themselves, and then discontinue their pursuit. Such was formerly the practice in England; and as late as the reign of Charles $\mathrm{I}$. there was an officer of the household who bore the title of Master of the Cormorants.

\section{THE BLACK AND WHITE GULL. (Larus marinus.)}

GuLLs frequent principally the northern countries, and do not dive so much as the other water fowl; they chiefly subsisting on the gregarious fish which they catch near the surface of the water. When the sea is rough, they come into the harbours, and feed on worms. Occasionally they will even eat carrion. They fly with great rapidity; their body being light, and their wings long. It is not until the 
third year that the young birds acquire the same colour as the olit.

The Black and White Gull is by far the largest of all the Gull kind, as it generally weighs upwards of four pounds, and is twenty-five or twenty-six inches from the point of the bill to the end of the tail; and from the tip of each wing, when extended, five feet and several inches. The bill appears compressed sideways, being more than three inches long, and hooked towards the end, like the rest of this kind, of a sort of orange colour; the nostrils are of an oblong form; the mouth is wide, with a long tongue and very open gullet. The irides of the eyes are of a very delightful red. The wings and the middle of the back are black, only the tips of the covert and quill-feathers are white. The head, breast, tail, and other parts of the body are likewise white. The tail is near six inches long, the legs and feet are flesh-coloured, and the claws black. There are about twenty varieties of this tribe, which are all distinguished by an angular knob on the chap.

Gulls are found in great plenty in every place; but it is chiefly round our rockiest shores, that they are seen in the greatest abundance; it is there that the Gull breeds and brings up its young; it is there that millions of them are heard screaming with discordant notes for months together.

These birds, like all others of the rapacious kind, lay but few eggs; and hence, in ziany places, their number is daily seen to diminish. The lessening of so many rapacious 10 
birds may, at first sight, appear a benefit to mankind; but when we consider how many persons are sustained by their flesh, either fresh or salted, we shall find no satisfaction in thinking that these poor people may in time lose their chief support. The Gull usually builds on the ledges of rocks, and lays from one egg to three, in a nest formed of long grass and sea-weed. It defends its young with great intrepidity. When the natives of the Fero Islands attempt to plunder the nest, the parent birds attack them with such vehemence that, on the men holding a knife perpendicularly above their own heads, the Gulls will sometimes transfix themselves in pouncing on the invaders. Most of the kind are fishy tasted, with black stringy flesh; yet the young ones are better food; and of these, with several other birds of the penguin kind, the poor inhabitants of the Arctic regions make their wretched banquets. They have been long used to no other food; and even a salted Gull can be relished by those who know no better.

\section{THE GREAT TERN. (Sterna hisundo.)}

THIs bird is about fourteen inches long, and weighs four ounces and a quarter. The bill and feet are a fine crimson, the former is tipped with black, and very slender. The back of the head is black; the upper part of the body is a 
pale gray, and the under part white. They have been called Sea Swallows, from appearing to have all the same actions at sea that the swallow has on land, seizing every insect which appears on the surface, and darting down upon the smaller fishes, which they seize with incredible rapidity.

The Lesser Tern weighs only two ounces five grains. The bill is yellow, and from the eyes to the bill is a black line: in other respects it almost exactly resembles the preceding.

The Black Tern is of a middle size between the two preceding species. It weighs two ounces and a half. It receives its name from being all black as far as the vent, except a white spot under the throat. This bird is called in some parts the Car Swallow. It is very noisy.

Among the birds of this tribe, one of the most singular is the Striated Tern, which is a native of New Zealand. It has a black bill, and the body is in general mottled, or rather striped with black and white. Its length is about thirteen inches.

\section{PURPLE GALLINULE. (Gallinula porphyrio.)}

"This bird," says Latham, "is more or less common in all the warmer parts of the globe. On the coasts of Barbary they abound, as well as in some of the islands of the 
Mediterranean. In Sicily, they are bred in plenty, and kept for their beauty; but whether indigenous there, we are not certain. It is frequently met with in various parts of the south of Russia, and western parts of Siberia, among reedy places; and in the neighbourhood of the Caspian Sea not uncommon; but in the cultivated rice grounds of Ghilan in Persia, in great plenty, and in high plumage. The female makes her nest among the reeds, in the middle of March; lays three or four eggs, and sits from three to four weeks. That it is common in China, the paper-hangings thence will everywhere testify. It is also met with in the East Indies, the islands of Java, Madagascar, and many others. Our late navigators saw them at Tongataboo in vast numbers, as well as the islands of Tanna, and other parts. It is also common in the southern parts of America.

"In respect to its manners, it is a very docile bird, being easily tamed, and feeding with the poultry, scratching the ground with the foot, as the cock and hen. It will feed on many things, such as fruits, roots of plants, and grain; but will eat fish with avidity, dipping them into the water before it swallows them; will frequently stand on one leg, and lift the food to its mouth with the other, like a parrot. The flesh is said to be exquisite in taste."

"The moderns," says Buffon, "have given the name of Sultana Hen to a bird famous among the ancients, under the name of Porphyrion. We have frequently had occasion to remark the justness of the denominations bestowed by 
the Greeks, which generally allude to the distinctive characters, and are therefore superior to the terms hastily adopted in our languages, from superficial or inaccurate views. The present is an instance; as this bird seemed to bear some resemblance to the gallinaceous tribe, it got the name of Hen; but as, at the same time, it differed widely, and excelled by its beauty and port, it received the epithet of Sultana. But the term Porphyrion, indicating the red or purple tint of its bill and feet, was more just and characteristic; and should we not rebuild the fine ruins of learned antiquity, and restore to nature those brilliant images, and thuse faithful portraits from the delicate pencil of the Greeks, ever awake to her beauties and her animation?

"Both the Greeks and Romans, notwithstanding their voracious luxury, abstained from eating the Porphyrion. They brought it from Lybia, from Comagene, and from the Balearic Islands, to be fed and to be placed in their palaces and temples, where it was left at liberty as a guest, whose noble aspect, whose gentle disposition, and whose elegant plumage, merited such honours.

"Searcely any bird has more beautiful colours; the blue of its plumage is soft and glossy, embellished with brilliant reflections; its long feet, and the plate from the top of its head to the root of its bill, are of a fine red; and a tuft of white feathers under the tail heightens the lustre of its charming garb. Except that it is rather smaller, the female 
differs not from the male, which exceeds the partridge, but is inferior to a domestic hen. The Marquis de Nesle brought a pair from Sicily, where they are known under the name of Gallofagiani; they are found on the lake Lentini, above Catana, and are sold for a moderate price in that city, as well as in Syracuse and the adjacent towns. They appear alive in the public places, and plant themselves beside the sellers of vegetables and fruits to pick up the refuse; and this beautiful bird, which the Romans lodged in their temples, now experiences the decline of Italy."

The length of the Purple Gallinule is fourteen inches; its bill is an inch and a quarter long, red, yellow at the tips; nostril, small, oblong, and near the centre of the bill; irides, tawny; the naked front and crown are red; the head, part of the neck, throat, and breast are of a rich violet purple; the back and scapulars, brownish-green; rump, tail, and its coverts, of a duller brownish-green; the sides of the neck, ultramarine; wings, the same, tinged with green; the inner webs of the quill-feathers and tail, dusky brown; upper lining and side lining of the wings, under the spurious wing, rich light blue; the belly, thighs, and for an inch behind, dull purplish black; the vent pure white; tail, rounded; thighs, legs, and feet, red; span of the foot, five inches; hind toe and claws, long. 


\section{GREAT NORTHERN DIVER, OR LOON. \\ (Colymbus glacialis.)}

TuIs bird in Pennsylvania is migratory. In the autumn, it makes its appearance with the various feathered tribes that frequent our waters; and, when the streams are obstructed with ice, it departs for the Southern States. In the months of March and April, it is again seen, and, after lingering a while, it leaves us for the purpose of breeding. The Loons are found along the coast, as well as in the interior; but in the summer they retire to the fresh-water lakes and ponds. We have never heard that they breed in Pennsylvania, but it is said they do in Missibisci Pond, near Boston, Massachusetts. The female lays two large brownish eggs. They are commonly seen in pairs; and procure their food, which is fish, in the deepest water of our rivers, diving after it, and continuing under for a length of time. Being a wary bird, it is seldom they are killed, eluding their pursuers by their astonishing faculty of diving. They seem averse from flying, and are but seldom seen on the wing. They are never eaten.

The Loon is restless before a storm ; and an experienced master of a coasting-vessel informed me that he always knew when a tempest was approaching by the cry of this bird, which is very shrill, and may be heard at the distance of a mile or more. 
This species seldom visits the shores of Britain, except in very severe winters; but it is met with in the north of Europe, and spreads along the Arctic coast as far as the mouth of the river $\mathrm{Ob}$, in the dominions of Russia. It is found about Spitzbergen, Iceland, and Hudson's Bay. Nakes its nest, in the more northern regions, on the little isles of fresh-water lakes : every pair keep a lake to themselves. It sees well, flies very high, and, darting obliquely, falls secure into its nest. Appears in Greenland in April, or the beginning of May, and goes away in September, or October, on the first fall of snow. It is also found at Nootka Sound, and Kamtschatka.

The Parabinzians - a nation situated between the river 01 and the Irtisch, in the Russian dominions - tan the breasts of this and other water fowl, whose skins they prepare in such a manner as to preserve the down upon them; aud, sewing a number of these together, they sell them to make pelisses, caps, \&c. Garments made of these are very warm, never imbibing the least moisture, and are more lasting than could be imagined.

The natives of Greenland use the skins for clothing, and the Indians about Hudson's Bay adorn their heads with circlets of their feathers.

Lewis and Clark's party, at the mouth of the Columbia, saw robes made of the skins of Loons, and abundance of these birds, during the time that they wintered at Fort Clatsop, on that river. 
The Laplanders, according to Regnard, cover their heads with a cap made of the skin of a Loom (Loon), which word signifies in their language, lame, because the bird cannot walk well. They place it on their head in such a manner that the bird's head falls over their brow, and its wings cover their ears.

"Northern Divers," says Hearne, "though common in Hudson's Bay, are by no means plentiful; they are seldom found near the coast, but more frequently in fresh-water lakes, and usually in pairs. They build their nests at the edge of small islands, or the margins of lakes or ponds; they lay only two eggs; and it is very common to find only one pair and their young in one sheet of water-a great proof of their aversion to society. They are known in Hudson's Bay by the name of Loons."

The Great Northern Diver measures two feet ten inches from the tip of the bill to the end of the tail, and four feet six inches in breadth.

\section{BLACK-HEADED GULL. (Larus ridibundus.)}

Length, seventeen inches; extent, three feet six inches; bill, thighs, legs, feet, sides of the mouth, and eyelids, dark blood red; inside of the mouth, vermilion; bill, nearly two 
inches and a half long; the nostril is placed rather low; the eyes are black; above and below each eye there is a spot of white; the head and part of the neck are black, remainder of the neck, breast, whole lower parts, tailcoverts, and tail, pure white; the scapulars, wing-coverts, and whole upper parts, are of a fine blue ash colour; the first five primaries are black towards their extremities; the secondaries are tipped largely with white, and almost all the primaries slightly; the bend of the wing is white, and nearly three inches long; the tail is almost even; it consists of twelve feathers, and its coverts reach within an inch and a half of its tip; the wings extend two inches beyond the tail; a delicate blush is perceivable on the breast and belly.

The head of the female is of a dark dusky slate colour; in other respects, she resembles the male.

We are inclined (says Wilson) to the opinion, that the three Gulls of Latham, viz., the Black-headed Gull, the Red-legged Gull, and the Laughing Gull, are one and the same species, the very bird which we have been describing, the difference in their markings arising from their age and sex. We feel emboldened to this declaration from the circumstance of having ourselves shot Gulls which corresponded almost precisely to those of the above author, of the same habits, the same voice, and which were found associating together.

In some individuals, the crown is of a dusky gray; the 
upper part and sides of the neck, of a lead colour; the bill and legs, of a dirty, dark, purplish brown. Others have not the white spots above and below the eyes; these are young birds.

The changes of plumage, to which birds of this genus are subject, have tended not a little to confound the naturalist; and a considerable collision of opinion, arising from an imperfect acquaintance with the living subjects, has been the result. To investigate thoroughly their history, it is obviously necessary that the ornithologist should frequently explore their native haunts; and, to determine the species of periodical or occasional visiters, an accurate comparative examination of many specimens, either alive or recently killed, is indispensable. Less confusion would arise among authors, if they would occasionally abandon their accustomed walks - their studies and their museums, and seek correct knowledge in the only place where it is to be obtainedin the grand temple of nature. As it respects, in particular, the tribe under review, the zealous inquirer would find himself amply compensated for all his toil, by observing these neat and clean birds coursing along the rivers and coast, enlivening the prospect by their airy movements, now skimming closely over the watery element, watching the motions of the surges, and now rising into the higher regions, sporting with the winds, - while he inhaled the invigorating breezes of the ocean, and listened to the soothing murmurs of its billows. 


\section{THE B L A C K-HEADED GULL.}

The Black-headed Gull is the most beautiful and most sociable of its genus. They make their appearance on the coast of New Jersey in the latter part of April; and do not fail to give notice of their arrival by their familiarity and loquacity. The inhabitants treat them with the same indifference that they manifest towards all those harmless birds which do not minister either to their appetite or their avarice; and hence the Black-Heads may be seen in companies around the farm-house, coursing along the river-shores, gleaning up the refuse of the fishermen, and the animal substances left by the tide; or scattered over the marshes and newly-ploughed fields, regaling on the worms, insects, and their larvæ, which, in the vernal season, the bounty of Nature provides for the sustenance of myriads of the feathered race.

On the Jersey side of the Delaware Bay, in the neighbourhood of Fishing Creek, about the middle of May, the Black-headed Gulls assemble in great multitudes, to feed upon the remains of the king-crabs which the hogs have left, or upon the spawn which those curious animals deposit in the sand, and which is scattered along the shore by the waves. At such times, if any one approach to disturb them, the Gulls will rise up in clouds, every individual squalling so loud, that the roar may be heard at the distance of two or three miles.

It is an interesting spectacle to behold this species when about recommencing their migrations. If the weather be 
calm, they will rise up in the air, spirally, chattering all the while to each other in the most sprightly manner, their notes at such times resembling the singing of a hen, but far louder, changing often into a haw, ha, $h a, h a$, haw! the last syllable lengthened out like the excessive laugh of a negro. When mounting and mingling together, like motes in the sunbeams, their black heads and wing-tips, and snowwhite plumage, give them a very beautiful appearance. After gaining an immense height, they all move off, with one consent, in a direct line towards the point of their destination.

This bird breeds in the marshes. The eggs are three in number, of a dun clay colour, thinly marked with small, irregular touches of a pale purple, and pale brown; some are of a deeper dun, with larger marks, and less tapering than others; the egg measures two inches and a quarter by one inch and a half.

The Black-Heads frequently penetrate into the interior, especially as far as Philadelphia; but they seem to prefer the neighbourhood of the coast for the purpose of breeding. They retire southward early in autumn.

\section{ILLUSTRATIVE ANECDOTES.}

This species is found in every part of Russia and Siberia, and even in Kamtschatka. They are seen throughout the winter at Aleppo, in great numbers, and so tame, that the women are said to call them from the terraces of their 
houses, throwing up pieces of bread, which these birds catch in the air.

The Black-headed Gull is common in Great Britain. "In former times," says Bewick, "these birds were looked upon as valuable property, by the owners of some of the fens and marshes in this kingdom, who, every autumn, caused the little islets or hafts, in those wastes, to be cleared of the reeds and rushes, in order properly to prepare the spots for the reception of the old birds in the spring, to which places at that season they regularly returned in great flocks to breed. The young ones were then highly esteemed, as excellent eating, and on that account were caught in great numbers, before they were able to fly. Six or seven men, equipped for this business, waded through the pools, and with long staves drove them to the land, against nets placed upon the shores of these hafts, where they were easily caught by the hand, and put into pens ready prepared for their reception. The gentry assembled from all parts to see the sport.

"Dr. Plot, in his Natural History of Staffordshire, published in 1686, gives the above particulars, and says that in this manner as many have been caught in one morning as, when sold at five shillings per dozen (the usual price at that time), produced the sum of twelve pounds ten shillings; and that in the several drifts on the few succeeding days of this sport, they have been taken in some years in such abundance, that their value, according to the above 



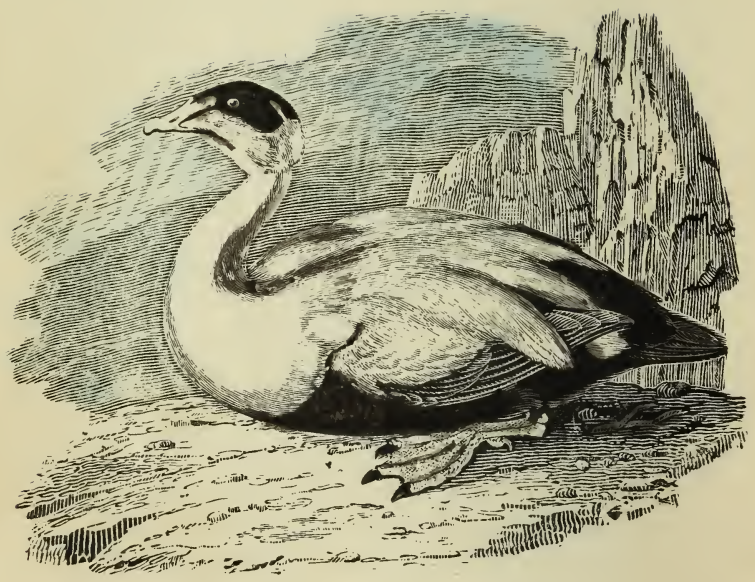


rate, was from thirty to sixty pounds - a great sum in those days. These were the See Gulles, of which we read as being so plentifully provided at the great feasts of the ancient nobility and bishops of this realm. Although the flesh of these birds is not now esteemed a dainty, and they are seldom sought after as an article of food, yet in the breeding season, where accommodation and protection are afforded them, they still regularly resort to the same old haunts, which have been occupied by their kind for a long time past. This is the case with the flocks which now breed at Pallinsburne, in Northumberland, where they are accounted of great use in clearing the surrounding lands of noxious insects, worms, slugs, \&c."

\section{THE EIDER DUCK. (Anas mollissima.)}

Tue Eider Duck has been long celebrated in Europe, for the abundance and excellence of its down, which, for softness, warmth, lightness, and elasticity, surpasses that of all other ducks. The quantity found in one nest more than filled the crown of a hat, yet weighed no more than threequarters of an ounce; and it is asserted, that three pounds of this down may be compressed into a space scarce bigger than a man's fist, yet is afterwards so dilatable as to fill a quilt five feet square. 
The native regions of the Eider Duck extend from $45^{\circ}$ $N$. to the highest latitudes yet discovered, both in Europe and America. Solitary rocky shores and islands are thcir farourite haunts. Some wandering pairs have been known to breed on the rocky islands beyond Portland, in the state of Maine, which is perhaps the most southern extent of their breeding place.

In England, the Fern Isles, on the coast of Northumberland, are annually visited by a few of these birds, being the only place in South Britain where they are known to breed. They occur again in some of the Western Isles of Scotland. Greenland and Iceland abound with them, and here, in particular places, their nests are crowded so close together, that a person can scarcely walk without treading on them.

The natives of these countries know the value of the down, and carry on a regular system of plunder, both of it and also of the eggs. The nest is generally formed outwardly of drift-grass, dry sea-weed, and such like materials; the inside composed of a large quantity of down, plucked from the breast of the female. In this soft, elastic bed she deposits five eggs, extremely smooth and glossy, of a pale olive colour; they are also warmly covered with the same kind of down. When the whole number is laid, they are taken away by the natives, and also the down with which the nest is lined, together with that which covers the eggs. The female once more strips her breast of the remaining down, and lays a second time; even this, with the eggs, is 
generally taken away; and it is said that the male, in this extremity, furnishes the third quantity of down from his own breast; but if the cruel robbery be a third time repeated, they abandon the place altogether.

One female, during the whole time of laying, generally gives half a pound of down; and we are told, that, in the year 1750, the Iceland Company sold as much of this article, as amounted to three thousand seven hundred and forty-five banco dollars, besides what was directly sent to Gluckstadt. The down from dead birds is little esteemed, having lost its elasticity.

These birds associate together in flocks, generally in deep water, diving for shell-fish, which constitute their principal food. They frequently retire to the rocky shores to rest, particularly on the appearance of an approaching storm. They are numerous on the coast of Labrador, and are occasionally seen in winter as far south as the Capes of Delaware. Their flesh is esteemed by the inhabitants of Greenland, but tastes strongly of fish.

\section{THE CANADA GOOSE. (Anas Canac'ensis.)}

This (says Wilson) is the Common Wild Goose of the United States, universally known over the whole country; 11 
whose regular periodical migrations are the sure signals of returning spring, or approaching winter. The tracts of their vast migratory journeys are not confined to the seacoast or its vicinity. In their aerial voyages to and from the north, these winged pilgrims pass over the interior, on both sides of the mountains, as far west, at least, as the Osage river; and $\mathrm{I}$ have never yet visited any quarter of the country where the inhabitants are not familiarly acquainted with the regular passing and repassing of the Wild Geese.

The general opinion here is, that they are on their way to the lakes to breed; but the inhabitants on the confines of the great lakes that separate us from Canada, are equally ignorant with ourselves of the particular breeding plaees of those birds. There, their journey north is but commencing; and how far it extends it is impossible for us, at present, to ascertain, from our little acquaintance with these frozen regions. They were seen by Hearne, in large flocks, within the Arctic circle, and were then pursuing their way still further north. Captain Phipps speaks of seeing Wild Geese feeding at the water's edge on the dreary coast of Spitzbergen, in lat. $80^{\circ} 27 \%$. It is highly probable that they extend their migrations under the very pole itself, amid the silent desolation of unknown countries, shut out since creation from the prying eye of man by everlasting and insuperable barriers of ice. That such places abound with their suitable food, we cannot for a moment doubt; 
while the absence of their great destroyer, man, and the splendours of a perpetual day, may render such regions the most suitable for their purpose.

Having fulfilled the great law of nature, the approaching rigours of that dreary climate oblige these vast, congregated flocks to steer for the more genial regions of the south. And no sooner do they arrive at those countries of the earth inhabited by man, than carnage and slaughter is commenced on their ranks. The English at Hudson's Bay, says Pennant, depend greatly on Geese, and in favourable years, kill three or four thousand, and barrel them up for use. They send out their servants, as well as Indians, to shoot these birds on their passage. It is in vain to pursue them; they therefore form a row of huts, made of boughs, at musket-shot distance from each other, and place them in a line across the vast marshes of the country. Each stand, or hovel, as it is called, is occupied by only a single person. These attend the flight of the birds, and, on their approach, mimic their cackle so well that the Geese will answer, and wheel, and come nearer the stand. The sportsman keeps motionless, and on his knees, with his gun cocked the whole time, and never fires till he has seen the eyes of the Geese. He fires as they are going from him; then picks up another gun that lies by him and discharges that. The Greese which he has killed he sets upon sticks, as if alive, to decoy others; he also makes artificial birds for the same purpose. 
In a good day,- - for they fly in very uncertain and unequal numbers, - a single Indian will kill two hundred. Notwithstanding every species of Goose has a different call, yet the Indians are admirable in their imitations of every one. The autumnal flight lasts from the middle of August to the middle of October; those which are taken in this season, when the frosts begin, are preserved in their feathers, and left to be frozen for the fresh provisions of the winter stock. The feathers constitute an article of commerce, and are sent to England.

The vernal flight of the Geese lasts from the middle of April until the middle of May. Their first appearance coincides with the thawing of the swamps, when they are very lean. Their arrival from the south is impatiently attended; it is the harbinger of the spring, and the month named by the Indians the Goose moon. They appear usually at their settlements about St. George's day, O. S., and fly northward, to nestle in security. They prefer islands to the continent, as further from the haunts of man.

After such prodigious havoc as thus appears to be made among these birds, and their running the gauntlet, if I may so speak, for many hundreds of miles through such destructive fires, no wonder they should have become more scarce, as well as shy, by the time they reach the shores of the United States.

Their first arrival on the coast of New Jersey is early in October, and their first numerous appearance is the sure 
prognostic of severe weather. Those which continue all winter frequent the shallow bays and marsh islands; their principal food being the broad, tender, green leaves of a marine plant which grows on stones and shells, and is usually called sea cabbage; and also the roots of the sedge, which they are frequently observed in the act of tearing up.

The Wild Goose, when in good order, weighs from ten to twelve, and sometimes fourteen pounds. They are sold in the Philadelphia markets at from seventy-five cents to one dollar each; and are estimated to yield half-a-pound of feathers apiece, which produces twenty-five or thirty cents more.

The Canada Goose is now domesticated in numerous quarters of the country, and is remarked for being extremely watchful, and more sensible of approaching changes in the atmosphere than the common gray goose. In England, France, and Germany, they have also been long ago domesticated.

\section{ILLUSTRATIVE ANECDOTE.}

Mr. Platt, a respectable farmer on Long Island, being out shooting in one of the bays, which, in that part of the country, abound with water-fowl, wounded a Wild Goose. Being wing-tipped, and unable to fly, he caught it, and brought it home alive. It proved to be a female; and, turning it into his yard, with a flock of tame geese, it soon became quite tame and familiar, and in a little time its 
wounded wing entirely healed. In the following spring, when the Wild Geese migrate to the northward, a flock passed over Mir. Platt's barn-yard ; and, just at that moment, their leader happening to sound his bugle-note, our Goose, in whom its new habits and enjoyments had not quite extinguished the love of liberty, and remembering the wellknown sound, spread its wings, mounted into the air, joined the travellers, and soon disappeared. In the succeeding autumn, the Wild Geese, as was usual, returned from the northward in great numbers, to pass the winter in our bays and rivers. Mr. Platt happened to be standing in his yard when a flock passed directly over his barn. At that instant, he observed three Geese detach themselves from the rest, and, after wheeling round several times, alight in the middle of the yard. Imagine his surprise and pleasure, when, by certain well-remembered signs, he recognised in one of the three his long-lost fugitive. It was she indeed! She had travelled many hundred miles to the lakes; had there hatched and reared her offspring; and had now returned with her little family, to share with them the sweets of civilized life. 


\section{THE SKUA GULL. (Lestris catarractes.)}

Tris daring Jager, or feathered pirate of the ocean (says Nuttall) has spread its dominion to the extremes of both hemispheres, dwelling chiefly on the hyperboreal or antarctic seas. It is found in the Hebrides, Orkney, Shetland, and Faroe Islands, as well as in Norway and Iceland. In America, it is found in the high northern regions; then again in many parts of the Pacific, at Port Egmont, in the Falkland Islands (hence called Port Egmont Hens.) In the latter end of December, their breeding season in that hemisphere, at Christmas Sound, in Terra del Fuego, they were found in great plenty, making their nests in the dry grass. They are also seen to the east of New Zealand. Such is the extensive geographic range of this species, according to Pennant and others, at the same time, we may fairly doubt the identity of the northern and southern birds, since they are but rarely seen on their passage any great distance towards the south. Off the coast of Newfoundland, probably this species is seen in June, widely exploring the ocean, and in the depth of winter they migrate into the bays along the coast of Massachusetts, but I believe they are nearly unknown as far south as the coast of New Jersey.

As the supposed identic species of the two hemispheres appear therefore never to meet in their range to warmer 
countries, proceeding rarely, if ever, into the tropics, we may almost rest satisfied that, however closely allied, they are still of distinct races, originating from different creative points of the globe.

The Cataract Yager, so called by Linnæus from the rapidity and violence with which it darts down on its prey, is a very bold and voracious species. Like the eagle it sometimes pounces upon the domestic flocks, and tearing up a lamb, carries the mangled pieces to feed its craving brood. In the rocky island of Foula, however, better supplied with its ordinary fare from the deep, it even refrains from injuring the poultry, and in its enmity to the eagle, defends the flocks from its attacks; so different, according to circumstances, are the habits and propensities of animals.

It however often preys on the small gulls and other birds with all the rapacity of a hawk, and for which its powerful claws seem to indicate both the ability and instinctive inclination. It is often, at the same time, satisfied with seizing on the fish, which its accidental provider easily disgorges whenever alarmed. In defence of its young its temerity scarcely knows any bound. It will at such times often attack a whole company of men, should they disturb it, or molest its cherished brood.

After the breeding season, old and young take to the sea, in small companies or pairs, and venture, like the albatross, boldly and securely over the wide ocean. Off the stormy 
Cape of Good Hope and Cape Horn, as in the middle of the vast Atlantic, these black and piratical birds, like weathered mariners, are seen to levy their contributions upon the inhabitants of the deep, soaring on high above the mountain wave, and flying out in easy circling tours like so many boding ravens, occasionally reconnoitring at a distance the sailing vessel that accidentally ventures across their wide and desolate domain.

In the southern hemisphere, bold and predaceous by privation, the Skua Jager is frequently seen to attack the gigantic albatross, beating it with violence while on the wing, and who generally escapes from the daring freebooter alone by settling down into the water. Still the Jager himself succumbs to the rage and violence of the elements, and at the approach, or during the continuance of the tempest, he condescends to seek out the shelter of the bay or the neighbouring coast. They are also not unfrequently associated with the common tern, and have a somewhat similar cry.

The Skua, like the larger Gulls, commonly feeds on fish and mollusca, as well as on carrion and cetaceous animals, and seeking out the nests of other marine birds, he robs them frequently of their eggs. They nest themselves in the remote and cold regions, associating in large bands, on the summits of mountains, or in the herbage and heath contiguous to the coast. They lay three or four very pointed olivaceous eggs, sprinkled with large brown spots. 


\section{THE WOODCOCK. (Rusticola minor.)}

The American Woodcock, like the snipe, appears again to be a near representative of that of Europe, whose manners and habits it almost entirely possesses, differing, however, materially in the temperature of the climates selected for its residence, confining itself in the summer to the south side of the St. Lawrence, breeding in all the intermediato space as far as the limits of the Middle States, and retiring in winter, for the most part, either to or beyond the boundary of the Union.

The European species, on the contrary, courting cooler climates, winters in Great Britain and the north of Europe, and retires as early as March, to breed in the Alps or in the frigid wilds of Sweden, Norway, Russia, and penetrates even to the icy shores of Greenland, and the heaths of Iceland. About the same period, early in March, the American Woodcock revisits Pennsylvania, and soon after the New England or Eastern States. Indeed, so sedentary is the species at times, that a few are known to winter in the sheltered forests and open watery glades of Pennsylvania; at the same season also, many are seen in the vicinity of Natchez, in Mississippi.

According to their usual habits, they keep secluded in the woods and thickets, till the approach of evening, when they sally forth to seek out springs, paths, and broken soil, in quest of worms and other insects, on which they feed. 
They now disperse themselves over the country to breed, and indicate their presence in all directions by the marks of their boring bills, which are seen in such soft and boggy places as are usually sheltered by thickets and woods. They also turn over the fallen leaves from side to side with their bills in quest of lurking insects, but never scratch with their feet, though so robust in their appearance.

The sensibility possessed by the extremity of the bill, as in the snipe, is of such an exquisite nature, that they are enabled to collect their food by the mere touch, without using their eyes, which are set at such a distance and elevation in the back part of the head, as to give the bird a remarkable aspect of stupidity. When flushed or surprised in their hiding-places, they only rise in a hurried manner to the tops of the bushes, or glide through the undergrowth to a short distance, when they instantly drop down again, and run out for some space on touching the ground, lurking as soon as they imagine themselves in a safe retreat. At times, in open woods, they fly out straight with considerable vigour and swiftness, but the effort, from the shortness of the wing, is always attended with much muscular exertion.

Early in April, the Woodcocks in pairs select a spot for breeding, which is generally in or near some retired part of the same woods which usually affords them their food and shelter. The nest is placed on the ground, in a tuft of grass, or in the protection of some old stump. It is formed 
with little art, of such withered leaves and old grass as the convenience of the place affords; the eggs are four, rather large, of a dark yellowish-white approaching olive, specked and confluently blotched with three slightly different shades of dark yellowish-brown spots, most numerous at the greater end. Eggs have been found, even in Massachusetts, in sheltered woods, as early as the month of February; but the usual time, according to the age and general appearance of the young, is not before the commencement of April.

At this time, in the morning, as well as evening, but more particularly the latter, the male, in the vicinity of his mate and nest, rises successively in a spiral course, like a lark. While ascending he utters a hurried and feeble warble; but in descending the tones increase as he approaches towards the ground, and then, becoming loud and sweet, passes into an agreeable, quick, and tumultuous song. As soon as the performer descends, the sound ceases for a moment, when with a sort of stifled utterance, accompanied by a stiff and balancing motion of the body, the word blaik, and sometimes paip paip is uttered. This uncouth and guttural bleating seems a singular contrast to the delightful serenade, of which this is uniformly the close.

I heard this piping and bleating (says Mr. Nuttall) in the marshes of West Cambridge, on the 15th of April, and they had arrived about the first week in that month. This nocturnal music continued at regular intervals, and in succes- 
sion, until near nine o'clock in the evening, and is prolonged for a number of days during the period of incubation, probably ceasing with the new cares attendant on the hatching of the brood. The female, as in the European species, is greatly attached to her nest, and an instance is related to me of a hen being taken up from it, and put on again without attempting to fly.

\section{ILLUSTRATIVE ANECDOTES.}

Mr. Latham mentions a female of the common Woodcock sitting on her eggs so tamely, that she suffered herself to be stroked on the back without offering to rise, and the male, no less interested in the common object of their cares, sat also close at hand. The European species has had the credit of exercising so much ingenuity and affection, as to seize upon one of its weakly young, and carry it along to a place of security from its enemies.

Mr. Ives, of Salem, once on flushing an American Woodcock from its nest, was astonished to see that it carried off in its foot one of its brood, the only one which happened to be newly hatched; and as the young run immediately on leaving the shell, it is obvious that the little nurslings could be well reared, or all of them, as they might appear, without the aid of the nest, now no longer secured from intrusion.

In New England this highly esteemed game is common in the market of Boston to the close of October, but they 
all disappear in the latter part of December. In that quarter of the Union they are scarcely in order for shooting before the latter end of July, or beginning of August; but from this time to their departure, they continue in good condition for the table.

The springes or springers, set for Woodcocks in Europe, in places they are found to frequent by the evidence of their borings, \&c., are commonly formed of an elastic stick, to which is fastened a horse-hair noose, put through a hole in a peg, fastened into the ground, to which a trigger is annexed: and, in order to compel the Woodcock to walk into the trap, an extended fence is made on each side, by small sticks, set up close enough to prevent the bird passing between them; these concentrate at the trap, so that in this funnel-shaped fence, the bird, in feeding, is made to pass through the narrow passage, and is almost to a certainty caught by the legs.

As the season advances, and food begins to fail, by reason of inclement and cold weather, the Woodcocks leave the interior; and approaching the shelter of the sea-coast and the neighbouring marshes, they now become abundant, and are, at such times, late in autumn, killed in great numbers. These are also their assembling points previous to their southern migrations, which are performed in a desultory and irregular manner, their motions, as usual, being mostly nocturnal, or in the twilight; and though many are now met with in the same low meadows and marshes, they are 



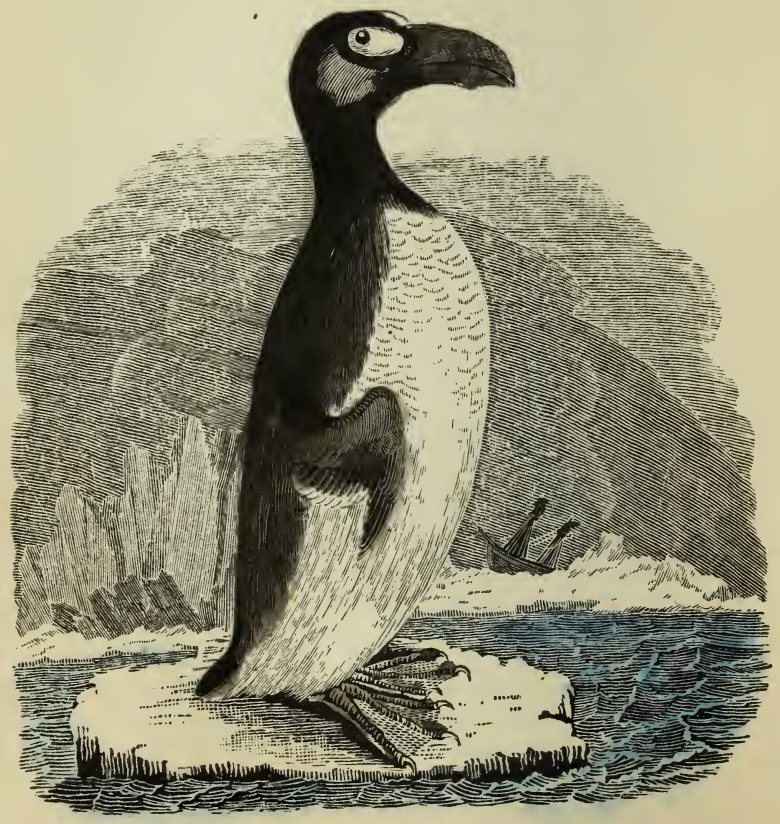


brought together by common necessity, and never move in concerted flocks.

At this season, their movements are not betrayed by any note or call; the vocal powers of the species are only called into existence at the period of propagation; at other times they move and start to wing in silence. The young run or wander off as soon as they are hatched, are at this period covered with a brownish-white down, and, on being taken, utter a slender bleat, or clear and long drawn péep.

\section{THE GREAT AUK. (Alca impennis).}

THIs bird is of the size of a goose; its bill is black, and covered at the base with short velvetlike feathers. The upper parts of the plumage are black, and the lower parts white, with a spot of white between the bill and the eyes, and an oblong stripe of the same on the wings, which are too short for flight. It is a very bad walker, but swims and dives well. It is, however observed by seamen, that it is never seen out of soundings, so that its appearance serves as an infallible direction to land. It feeds on the lumpfish, and others of the same size; and is frequently seen on the coasts of Norway, Greenland, Newfoundland, \&c. The female lays but one egg, which she hatches on a ledge, close to the seamark. 
There is another bird of this description, called the Penguin, of which there are several varieties, which seems to hold the same place in the southern parts of the world, that the Auks do in the northern; being only found in the temperate and frigid zones of the southern hemisphere. It resembles the former in almost all its habits: walking erect, and being very stupid : it also resembles it in colour, shortness of wings, rapidity of swimming, mode of feeding, and of making its nest. These birds hatch their young in an erect position; and cackle like geese, but in a hoarser tone. The most remarkable kind is the Crested Penguin, which inhabits several of the South Sea islands, and which is sometimes called the Hopping Penguin, or Jumping Jack, from the circumstance of its leaping quite out of the water, sometimes to the height of three or four feet, when it meets an obstacle in its course.

\section{THE SNIPE. (Scolopax Wilsonii.)}

The Snipe of North America, so nearly related to that of Europe, is found according to the season, in every part of the continent, from Hudson's Bay to Cayenne, and does not appear indeed sufficiently distinct from the Brazilian Snipe of Swainson, which inhabits abundantly the whole of 
South America as far as Chili. Many winter in the marshes and inundated river-grounds of the Southern States of the Union, where they are seen in the month of February, frequenting springs and boggy thickets; others proceed along the coast of the Gulf of Mexico, and even penetrate into the equatorial regions.

By the second week in March, they begin to revisit the marshes, meadows, and low grounds of the Middle States, and soon after they arrive in New England. In mild and cloudy weather, towards evening, and until the last rays of the setting sun have disappeared from the horizon, we hear, as in the north of Europe, the singular tremulous murmurings of the Snipes, making their gyratory rounds so high in the air as scarcely to be visible to the sight. This humming, or rather flickering and somewhat wailing sound, has a great similarity to the booming of the night-hawk; but more resembles the sound produced by quickly and interruptedly blowing into the neck of a large bottle than the whirring of a spinning-wheel.

But, however difficult and awkward may be our attempts to convey any adequate idea of this quailing murmur, it seems to be, to its agent, an expression of tender feeling or amatory revery, as it is only uttered at the commencement, and during the early part of the pairing season, while hovering over those marshes or river-meadows, which are to be the cradle and domicil of their expected progeny, as they have already been of themselves and their mates. 
This note is probably produced by an undulatory motion of air in the throat, while in the act of whirling flight; and appears most distinct as the Snipe descends towards the ground. However produced, the sound and its originators are commonly so concealed by the fast closing shades of night, and the elevation from whence it issues in cloudy weather, that the whole seems shrouded in mystery.

My aged maternal parent (says Mr. Nuttall) remembered, and could imitate with exactness this low wailing murmur, which she had for so many years heard over the marshes of my native Ribble, in the fine evenings of spring, when all nature seemed ready to do homage for the bounties of the season; and yet at the age of seventy, the riddle had not been expounded with satisfaction.

Over the wide marshes of Fresh Pond, about the middle of April, my attention was called to the same invisible voice, which issued from the floating clouds of a dark evening; the author was here called the Alewife Bird, from its arrival with the shoals of that fish in the neighbouring lake.

From the elevation at which the sound issued, probably, it appeared less loud and distinct than that which I have since heard from the English Snipe. I imagined then, that the noise was made by the quick and undulatory fanning of the wings, but this would not produce the shrillness of tone by which it is characterized, as any one may satisfy himself by hearkening to the very different low buzz 
made by the wings of the humming bird. In this instance, as well as in the former, all my sporting acquaintance were familiar with this quivering call, but had never decided upon its author.

At the same time, probably instigated by anger and jealousy, I observed flying high and rapid, a pair of these Snipes, who then uttered a discordant quacking sound; something like the bleat they make when they have descended to the ground, and which they accompany with an attitude of peculiar stupidity, balancing the head forwards, and the tail upwards and downwards, like the action of some automaton toy, jerked and set in motion by a tightdrawn string.

After incubation, which takes place rather early in the spring, the humming is no longer heard, and the sprightly aerial evolutions which appeared so indefatigable, have now given way to sedater attitudes and feebler tones. A few pairs no doubt breed in the extensive and almost inaccessible morasses of Cambridge ponds or lagoons; and I have been informed, that they select a tuft of sedge for the foundation of the nest, which is constructed with considerable art; the eggs, like those of the European species, about four, are perhaps alike olivaceous and spotted with brown.

They probably scatter themselves over the interior of the continent to breed, nowhere associating in great numbers; nor are they at all common in the hyperboreal retreats chosen by so many of the other wading birds. My friend, 
Mr. Ires, of Salem, also informs me, that a few pairs of this species breed in that vicinity.

The Snipe, almost nocturnal in its habits, conceals itself with assiduity in the long grass, sedge, and rushes of its enswamped and boggy retreat. Aware of danger from the approach of the sportsman, it springs at a distance with great rapidity, uttering usually a feeble squeak ; and making several inflections before it takes a direct course, it becomes very difficult to shoot, and is more easily caught with a snare or springe similar to that which is set for woodcocks. Being, deservedly, in high repute, as an exquisite flavoured game, great pains are taken to obtain Snipes.

In the spring season, on their first arrival, they are lean; but in the autumn, assembled towards the coast from all parts of the interior, breeding even to the banks of the Mississippi, they are now fat and abundant, and, accompanied by their young, are at this time met with in all the low grounds and enswamped marshes along the whole range of the Atlantic; but ever shy and dexterous, they are only game for the most active and eager sportsmen. When on the wing, they may, like many other birds of this family, be decoyed and attracted by the imitation of their voice.

They are, like the European Snipe, which migrates to winter in England, by no means averse to cold weather, so long as the ground is not severely frozen, in such a manner as to exclude their feeding; so that even in Massachusetts they are found occasionally down to the middle of December. 
They are nowhere properly gregarious, but only accidentally associate, where their food happens to be abundant. For this purpose they are perpetually nibbling and boring the black marshy soil, from which they sometimes seem to collect merely the root-fibres which it happens to contain, though their usual and more substantial fare consists of worms, leeches, and some long-legged aquatic insects; the Snipe of Europe also seizes upon the smaller species of Scarabceus. Their food, no doubt, is mixed with the black and slimy earth they raise while boring for roots and worms, and which, in place of gravel, or other hard substances, appears to be the usual succedaneum they employ to assist their digestion and distend the stomach.

\section{THE CAROLINA RAIL. (Rallus Carolinus.)}

The Soree, or Common Rail of America, which assemble in such numbers on the reedy shores of the larger rivers, in the Middle and adjoining warmer states, at the approach of autumn, and which afford such abundant employ to the sportsman, at that season, like most of the tribe to which it belongs, is a bird of passage, wintering generally south of the limits of the Union.

They begin to make their appearance, in the marshes of 
Georgia, by the close of February; and, on the 2d of May, Wilson observed them in the low watery meadows below Philadelphia. In the remote fur countries of the north, up to the $62 \mathrm{~d}$ parallel, they are common through the summer, and were observed by Dr. Richardson to be particularly abundant on the banks of the small lakes that skirt the Saskatchewan plains. In the rast reedy marshes, swamps, and lagoons of these desolate regions, the greater part of the species are no doubt reared, as but few of them are ever known to breed in the warmer parts of the continent, and the history of their manners, at the period of incubation, is, therefore, still a blank.

The observations of persons not conversant with the nice distinctions necessary in natural history, ought to be received with caution, as they might easily confound the mere young of the present and the preceding species, as one and the same. The alleged nest, eggs, and young birds covered with a black down, mentioned by Wilson, agree perfectly with the Virginian Rail; but the length of the bill, and any other discriminating particulars, are wholly omitted.

We may conclude, therefore, up to the present time, that the actual young and nest of the Soree are yet unknown, and that all which has been said on this subject is but conjecture, or a misapplication of facts belonging to the preceding species.

Like the other migrating waders, the Rails, accompanied by their swarming broods, bred in the north and west, 


\section{TII CAROLINA RAIL.}

begin to show themsclves on the reedy borders of the Delaware, and other large waters of the Middle States, whose still and sluggish streams, spreading out over muddy flats, give birth to an abundant crop of the seeds of the wild rice, now the favourite food of the Rails and the rice birds.

On first arriving, from the labour and privation incident to their migrations, they are lean, and little valued as food; but as their favourite natural harvest begins to swell out and approach maturity, they rapidly fatten; and, from the middle of September to the same time in October, they are in excellent order for the table, and eagerly sought after wherever a gun can be obtained and brought into operation.

Walking by the borders of these reedy rivers, in ordinary seasons, you hear, in all directions, the crowding Rails squeaking like young puppies. If a stone be thrown in amongst them, there is a general outcry through the reeds, a confused and reiterated ' $k u k$ ' $k u k$ ' $k u k$ ' $k$ ' $k$ ' $k$ ' $k$, resounds from the covered marsh, and is again renewed by the timid throng, on the discharge of a gun or any other sudden noise within their hearing.

The Rails, however numerous, are scarcely visible, unless it be at or near to high water; for when the tide is down, they have the art so well to conceal themselves among the reeds, that you may walk past and even over them, 
where there are hundreds, without seeing probably a single individual.

The flight of the Rails, while confined among the rice reeds, is low, feeble, and fluttering, with the legs hanging down, as if the effort were unnatural and constrained, which may, no doubt, at times, be produced by the extreme corpulency which they attain in a favourable season for food; yet, occasionally, they will rise to a considerable height, and cross considerable streams without any reluctance or difficulty; so that however short may be their wings, the muscles by which they are set in motion are abundantly sufficient to provide them the means of pursuing the deliberate stages of their migratory course. Wherever the Zizania and its nutritious grain abounds, there the Rails are generally seen.

In the reedy lakes of Michigan, as well as the tide-water streams of the Atlantic, these birds are found congregated, in quest of their favourite food. In Virginia, they are par ticularly abundant along the grassy banks of James River, within the bounds of tide-water, where they are often taken in the night, while perched among the reeds; being stupified by the glare of a fire carried in among them, they are then easily approached by a boat, and rudely knocked on the head with a paddle; sometimes in such quantities, that three negroes, in as many hours, have been known to kill from twenty to eighty dozen.

Fear seems to be a ruling passion among the whole tribe 
of Rails and their kindred allies; with faculties for acting in the day, timidity alone seems to have rendered them almost nocturnal in their actions; their sole address and cunning seems entirely employed in finding out means of concealment; this is particularly the case when wounded; they then swim out and dive with so much caution as seldom to be seen again above water; they even cling with their feet to the reeds beneath that element, where they would sooner endure suffocation than expose themselves with any chance of being seen; they often also skulk, on ordinary occasions, under the floating reeds, with nothing more than the bill above water.

At other times, when wounded, they will dive, and rise under the gunwale of the sportsman's boat, and secreting themselves there, have the cunning to go round as the vessel mores, until, given up as lost, they find an opportunity of completing their escape.

According to the observations of Mr. Ord, the females, more particularly, are sometimes so affected by fear, or some other passion, as to fall into sudden fits, and appear stretched out as lifeless, recovering, after a while, the use of their faculties, and falling again into syncope, on merely presenting the finger in a threatening attitude.

At such times, and during their obstinate divings, they often fall victims, no doubt, to their enemies in the watery element, as they are sometimes seized by eels and other voracious fish, who lie in wait for them; so that the verv 
excess of their fear and caution hurries them into additional dangers, and frustrates the intention of this instinct for preservation.

The swooning, to which they appear subject, is not uncommon with some small and delicate irritable birds, and canaries are often liable to these death-like spasms, into which they also fall at the instigation of some immaterial or trifling excitement of a particular kind.

During the greater part of the months of September and October, the market of Philadelphia is abundantly supplied with this highly esteemed game, and they are usually sold at from fifty cents to a dollar the dozen. But soon after the first frosts of October, or towards the close of that month, they all move off to the south. In Virginia, they usually remain until the first week in November. In the vicinity of Cambridge (Mass.), a few, as a rarity only, are now and then seen in the course of the autumn, in the Zizania patches which border the outlet of Fresh Pond; but none are either known or suspected to breed in any part of this state, where they are, as far as I can learn, everywhere uncommon.

\section{ILLUSTRATIVE ANECDOTES.}

The usual method of shooting Rail on the Delaware, according to Wilson, is as follows:-The sportsman proceeds to the scene of action in a batteau, with an experienced boatman, who propels the boat with a pole. About two 
hours before high water, they enter the reeds, the sportsman taking his place in the bow ready for action; while the boatman in the stern-seat pushes her steadily through the reeds.

The Rails generally spring singly, as the boat advances, and at a short distance ahead, are instantly shot down, while the boatman, keeping his eye on the spot where the bird fell, directs the vessel forward, and picks it up as the gunner is loading.

In this manner the boat continues through and over the wild-rice marsh, the birds flushing and falling, the gunner loading and firing, while the helmsman is pushing and picking up the game; which sport continues till an hour or two after high water, when its shallowness, and the strength and weight of the floating reeds, as also the unwillingness of the game to spring as the tide decreases, oblige them to return.

Several boats are sometimes within a short distance of each other, and a perpetual cracking of musketry prevails along the whole reedy shores of the river. In these excursions, it is not uncommon for an active and expert marksman to kill ten or twelve dozen in the serving of a single tide. 


\section{THE RUFF. (Tringa pugnax.)}

The Ruff (says Mr. Wilson), no less than the family of sandpipers, with which it is associated in the systems, is almost equally given to wandering, being found, according to the season, dispersed in flocks throughout the principal parts of the cold and temperate climates of the northern hemisphere. In spring they arrive in great numbers on the coast of Holland, Germany, Flanders, and England; they are equally abundant in Sweden, occur in Denmark, Norway, Finmark, and Iceland, and breed in the great desolate marshes of Siberia and Lapland, as well as in milder latitudes.

According to Skioldebrand, at Uleaborg, the capital of Ostrobothnia, they arrive in the spring, in such vast flocks, as almost to obscure the heavens, and resting on the floating ice, or on the banks of the rivers, fill the air with their confused cries; and the Ruffs, contending for their mates, appear like a pigmy army of pugilists. My friend, Mr. Cooper, about three years ago, obtained a specimen of the Ruff, from the shores of Long Island. From the rarity of this occurrence, we can only consider the Ruff, on the American coasts, as an accidental straggler; and their visits are probably more common on the western than the eastern side of the continent.

The Ruffs, like most of the birds, bred in high boreal latitudes, are under the necessity of migrating to milder climates, at the approach of winter. These northern hosts 
therefore now spread themselves over Europe, and the contiguous continents, until the return of spring invites them again to revisit the north. Different from the birds of the preceding section of this genus, the breeding limits of the Ruff extend from the marshes of England and Holland to the confines of the Arctic circle, and while the mass of the species are driven by the vicissitudes of the seasons to perform extensive migrations for the means of support, others, residing in milder climes, scarcely proceed further, in the course of the winter, than to the sea-coasts in the vicinity of their native marshes. At any rate, it appears certain, that the Ruff, unlike the sandpiper, never wanders into tropical climates. Come from where they may, they appear again in the eastern parts of Great Britain, to which their visits in that kingdom are now wholly confined, about the latter end of April, resorting to the fens of Lincolnshire, the Isle of Ely, and a few other places, which suit their peculiar habits.

In the month of May, the male, besides the red and carunculated face, acquires the curious and ornamental Ruff, which characterizcs the breeding season. It is scarcely completed in this month, and begins to fall in the latter end of June. With this singular decoration, he also undergoes a complete change in the rest of his plumage, the colours are more gay and brilliant; there is then a predominance of rufous and purple tints among the others, and the plain and sombre livery of winter is laid aside. 
Full of ardour and jealousy, the polygamous Ruffs now seek out the company of the Reeves, and when they have chosen a breeding-place, the males, so remarkable for their irritability, assemble upon some contiguous rising spot of ground, where, like so many professed duellists, erecting the ruff in a threatening attitude, they take their stand at a small distance from each other, and in their sight, combat for the society of their favourite females. This resort for amorous combat is at length so trodden, that the turf appears bare, and this battle-field thus betrays its company to their general enemy the fowler.

The Ruffs feed chiefly by night, repairing to the hill of contest about the dawn of day, and so pugnacious are they at this time, that they will often leap or flirt a yard from the ground, towards some wanderer or company who happen to be passing by; and an imitation of this hostile attitude, by a rudely stuffed bird jerked at the end of a long string, is often sufficient to decoy the passengers to alight in the snare. The pugnacious disposition of the Ruff, according to Mr. Baillon, is exhibited as soon as they appear in April, and before their arrival at their breeding-place. In the marshes of Montreuil-sur-Mer, where he had often occasion to follow them, he remarks, that their first object is to pair, or rather to fight with their rivals, while the feeble screams of the females rouse and exasperate their hostility, and their battles are often long, obstinate, and sometimes bloody. The vanquished betakes himself to flight, but the 
cry of-the first female he hears dispels his fears, and reawakens his courage, and he renews the conflict if another opponent appears. These skirmishes are repeated every morning and evening till their departure, in May.

As soon as the Reeves begin to lay, both those and their mates lay aside their wildness and desire of hostility, so that the whole may be caught with little effort. As the attachment of the females to their charge increases, with the progress of incubation, they become still more emboldened in its defence. At length, the period of excitement subsiding, the males, dropping their nuptial plumage, sink into tame and undistinguishable wanderers, and seceding from the Reeves and their brood, depart to their hybernal seclusion, in some distant country.

The females, associated in numbers, commence laying about the first or second week in May, and the young appear early in June. The nest is formed of grass, in a tussock of the same, in the most swampy part of the marsh. The eggs, four in number, very like those of the snipe, as well as the nest, are however larger, of a pale greenish hue, with a great number of small spots and points of dusky and brown. The Reeve is so remarkably attached to her eggs, that after being caught on the nest and carried some distance, on being liberated, she went again to her eggs, as if nothing had molested her. Indeed the attachment and courage of the female for her young, seem scarcely less remarkable than the pugnacious valour of the Ruff. 
The Ruffs, esteemed as a most delicate game, are so much sought after in England, as to be almost exterminated from many of their native marshes, and sell, when fattened artifcially, at from thirty shillings to two guineas the dozen. They are usually taken in large clap-nets, erected over the mounds that the Ruffs have selected for their daily combats. The fowler, repairing to the spot before daylight, spreads his net, places his decoy birds (which are either real prisoners of the species, or rudely stuffed skins), and takes his stand at the distance of about one hundred and forty yards, or more, according to the shyness of the birds. The net, suspended by poles, and commanded by a rope and pulleys, is at length pulled over its victims, and seldom fails of securing all within its reach.

Although their natural food consists of worms, and insects of the marshes where they dwell, when confined they are fed and fattened on milk and soaked bread, hempseed, sometimes boiled wheat, and to hasten the process sugar is frequently added to the rest of their fare. 


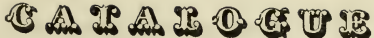

OF

\section{ILLUSTRATED AND ENTERTAINING}

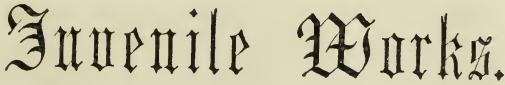

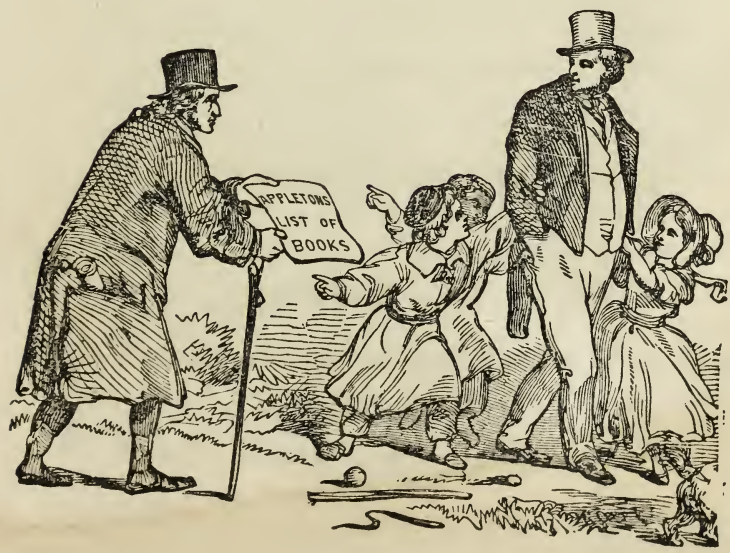

PUBLISHED BY

GEORGE S. APPLETON, 164 CHESTNUT ST.

UNDER BARNUM'S MUSEUM,

I' H I L D E L P H I A. 


\section{fittle Aumie's first Bool,}

CHIEFLY IN WORDS OF THREE LETTERS.

\section{BY HER MOTHER.}

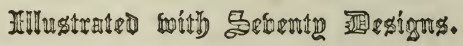

One Volume square $16 \mathrm{mo}$. Price 50 cents.

This little volume will commend itself to parents, as a book for ohildren who have just mastered the alphabet.

T H E

\section{TRAVELS}

AND

\section{EXTRAORDINARY ADVENTURES}

OF

\section{(Dob the Squirrel.}

\section{ILLUSTRATED WITH TWELVE ENGRAVINGS} BY DISTINGUISHED ARTISTS.

One Volume square $16 \mathrm{mo}$. Price 50 cents.

Bob's adventures are full of interest, and no child can fail to be mused and permanently benefited by the perusal of them. The ,ook is designed for a child from six to ten years of age. 
GEORGE S. APPLETON'S JUVENILE PUBLICATIONS.

\section{Claxa's Amusements.}

"Oh, happy childhood! whose sweet fruits of pleasure Are plucked in the safe garden of thy home."-M. S.

BY MRS. ANNA BACHE.

One Volume square $16 \mathrm{mo}$. Illustrated with original designs.

Price 50 cents.

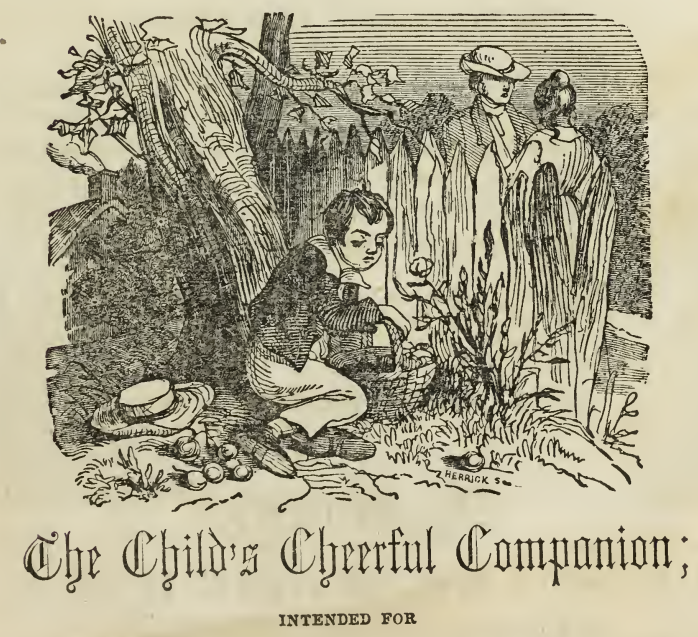

THE AMUSEMENT AND INSTRUCTION OF YOUNG PEOPLE.

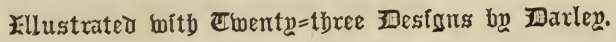

One Volume 15mo. Price $38 \mathrm{cts}$. 


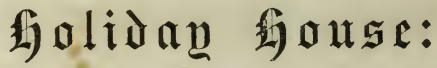 \\ A SERIES OFTALES}

By MISS SINCLAIR,

FROM THE THIRD LONDON EDITION.

\section{PRETTILY ILLUSTRATED BY CROOME.}

One Volume 16mo. Price 75 cents.

"We find in this volume, as in all of Miss Sinclair's other pro ductions, the same lively intellect, the same buoyant good humour, the same easy and vigorous style, the same happy talent for observation and description, the same warfare $a_{s}^{\prime}$ dinst the fashionable foilies of the day, and the same assiduity in inculcating the lessons of morality and religion."-Edinburgh Adve. iiser.

\section{THR}

\section{LIFE AND WANDERINGS}

or

\section{A $\mathfrak{A l} \mathfrak{d} \mathfrak{i t} \mathfrak{e}$.}

ILLUSTRATED WITH TEN LESIGNS BY CROOME, One Volume square $16 \mathrm{mo}$. P.ice 50 cents.

"An instructive and amusing volume, that will be read by every child with pleasure." 
GEORGE S. APPLETr.N'S JUVENILE PUBLICATIONS.

\section{The Clild's Owat Story Book;}

OR, TALES AND DIALOGUES FOR THE NURSERY.

BY MRS. JERRAM.

ILLUSTRATED WITH NUMEROUS ENGRAVINGS.

One Volume square $16 \mathrm{mo}$. Price 50 cents.

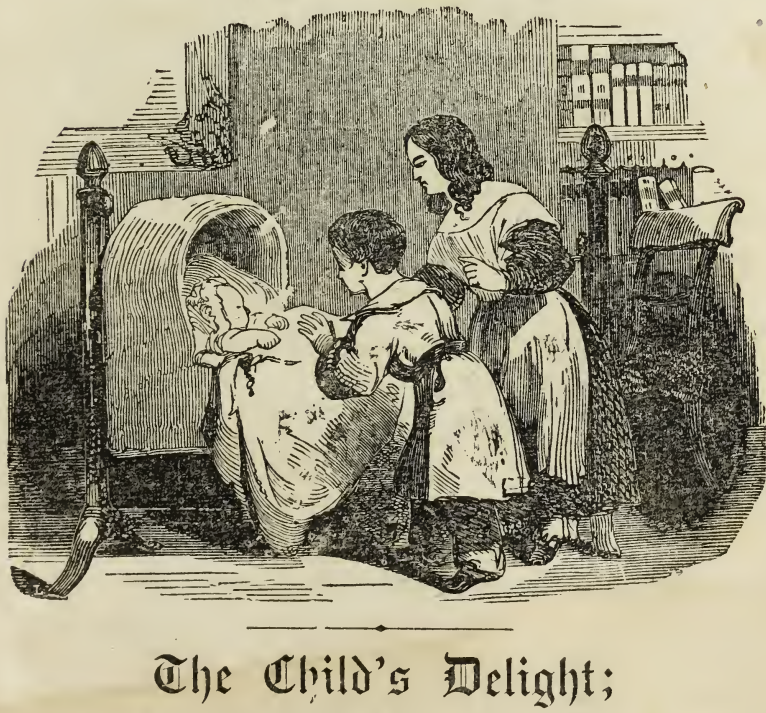

A GIFT FOR ALL SEASONS.

EDITED BY A LADY.

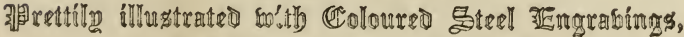

\section{DISIGIFD BY CROOME.}

One Volume square $16 \mathrm{mo}$. Price 50 cents. 
GEORGE S. APPLETON'S JUVENILE PUBLICATIONS.

\section{MARIA FDGIWORTH'S}

CHEAP JUVENILE WORKS.

WASTE NOT, WANT NOT:

or,

TWO STRINAS TO YOUR BOW.

BY MARIA EDGEWORTH.

One Volume square $16 \mathrm{mo}$. Price 25 cents.

LAZY LAWRENCE; OR,

INDUSTRY AND IDLENESS CONTRASTED. BY MARIA EDGEWORTH.

One Volume square $16 \mathrm{mo}$. Price 25 cents.

THE BRACELETS; OR,

AMIABILITY AND INDUSTRY REWARDED. BY MARIA EDGEWORTH.

One Volume square $16 \mathrm{mo}$. Price 25 cents.

THE FIRESIDE STORY BOOK; CONTAINING

"Lazy laWRence " "Waste not, Want nOt," and "THE bRacelets." ELEGANTLY ILLUSTRATED.

On Volume $16 \mathrm{mo}$. Price 50 cents. 


\section{GEORGE S. APPLETON'S JUVENILE PUBLICATIONS}

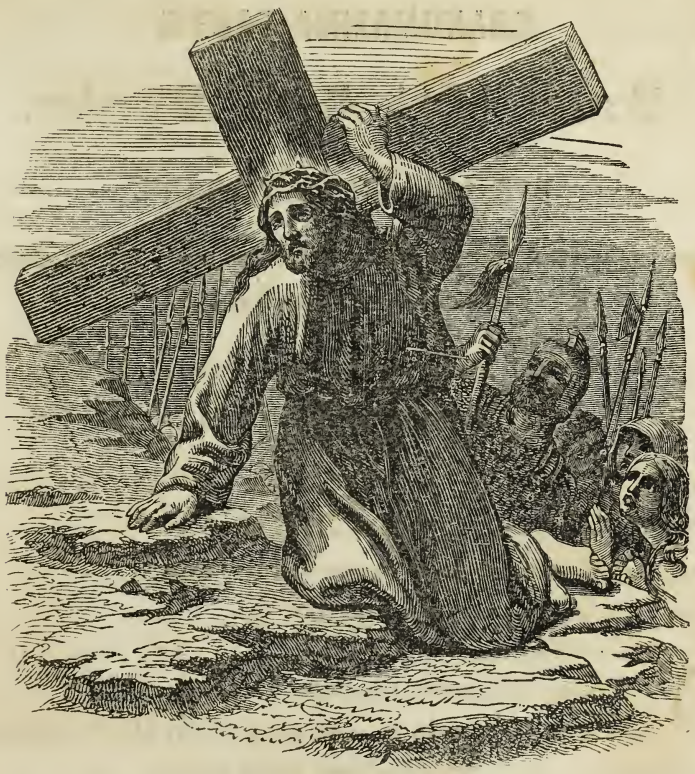

Atlamma's Bible Stories

FOR HER

\section{LITTLE BOYS AND GIRLS,}

A SERIES OF READING LESSONS TAKEN FROM THE BIBIE, AND ADAPTED TO THE CAPACITIES OF VERY YOUNG CHILDREN.

Ellustrateo bitt) nunrerous ZEngrabings.

One Volume square $16 \mathrm{mo}$. Price 50 cents. 
GEORGE 8. APPIETON'S JUVENILE PUBLICATIONS.

\section{GRANDMAMMA EASY'S

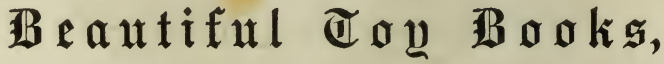 \\ FOR ALL GOOD CHILDREN.}

VERT LARGE STZE, PRINTED ON VERY LARGE TYPE, AND ELEGANTLY COLOURED, WITH GILT EDGES.

Put up in wrappers, each containing one dozen.

Price $\$ 150$ per Dozen.

CONTENTS.

New Story about Little Tom Thumb and his Mother.

New Little Stories about the Alphabet.

Merry Multiplication.

New Story about old Daddy Longlegs.

New Story about Little Jack Horner, and of what his Pie was made

Michaelmas Day, or the Fate of poor Molly Gaosey.

Alderman's Feast: A new Alphabet.

New Story about the Queen of Hearts, and the Stolen Tarts.

New Pictorial Bible Alphabet.

Toy Shop Drolleries, or Wonders of a Toy Shop.

Travels of Matty Macaroni, the Little Organ Boy.

New Story of Joseph and his Brethren. 
GEORGE S. APPLETON'S JUVENILE PUBLICATIONS.

\section{VERY LITTLE TALES FOR VERY LITTLE CHILDREN.}

In Single Syllables of three and four Letters. Large and bold Type. WITH NUMEROUS ILLUSTRATIONS.

Two Volumes $32 \mathrm{mo}$. Price 75 cents.

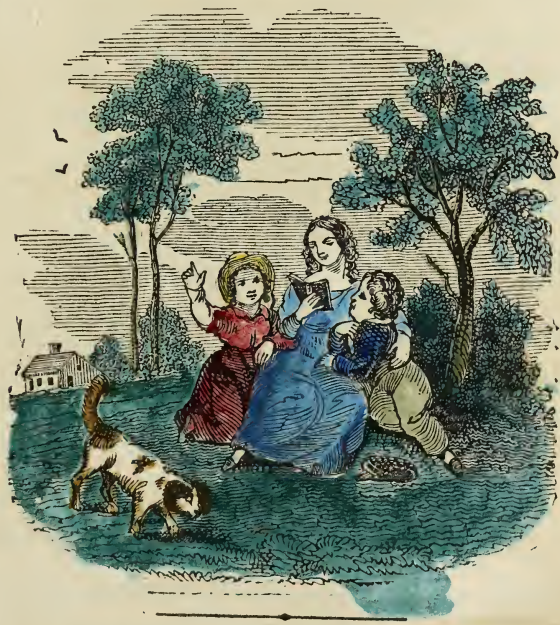

LITTLE LESSONS FOR LITTLE LEARNERS.

In words of one syllable.

BY MRS. BARWELL,

Author of "Mamma's Bible Stories."

One Volume square $16 \mathrm{mo}$. Price 50 cents. 


\section{GEORGE 8. APPLETON'S JUVENILE PUBLICATIONS.}

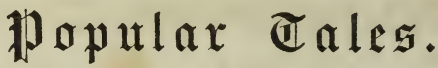

BY MARLA EDEEWORTH.

WITH ORIGINAL DESIGNS BY CROOME,

CON TENT $\mathbf{T}$.

\section{MURAD THE UNLUCKY. THE MANUFACTURERS. THE CONTRAST. THE GRATEFUL NEGRO. TO-MORROW.}

One Volume $16 \mathrm{mo}$. Price 75 cents.

" The writings of Maria Edgeworth have rarely been approached, and none have excelled her. Her stories are so natural, and are told with such truthfulness, that the reader becomes completely captivated."

\section{$\mathfrak{A l} \mathfrak{o} \mathfrak{x} \mathfrak{a}|\mathfrak{U} \mathfrak{a}| \mathfrak{k} \mathfrak{s}$.}

BY MARIA EDGEWORTH.

EMBELLISHED WITH ORIGINAL. DESIGNS BY DARLEY.

Price 75 cents.

"If we wished to do a young person good while offering amusement, to improve the heart while engaging the attention, and to give him or her little books which convey no false or distorted notions of life-Maria Edgeworth is our author." - Post. 
GEORGE S. APPLETON'S JUVENILE PUBLICATIONS.

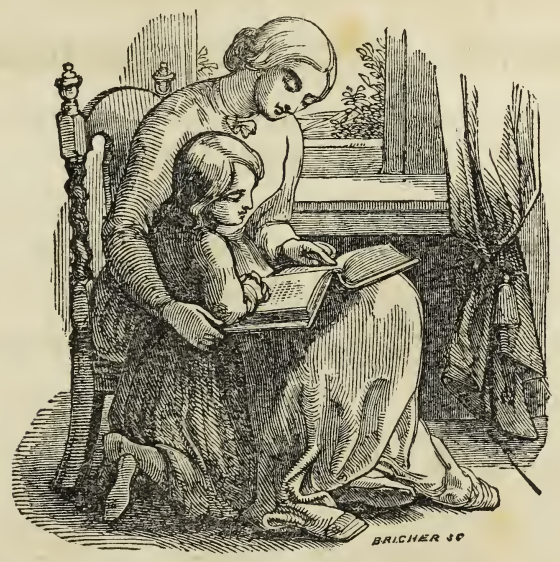

\section{甸ivine and Atloxal songs,}

FOR THE USE OF CHILDREN,

BI ISAAC WATIS, D.D.

ILLUS'TRATED WITH 24 ENGRAVINGS IN THE HIGHEST STYLE OF ART

One elegant volume, $16 \mathrm{mo}$. Price $75 \mathrm{cts}$

"This will be a constant furniture for the minds of children, that they may have something to think of when alone, and sing over to themselves. This may sometimes give their thoughts a divine turn, and raise a young meditation. Thus they will not be forced to seek relief for an emptiness of mind out of the loose and dangerous sonnets of the age." -Extract from Author's Preface. 


\title{
MRS. SHERWOOD'S
}

prettily IIllustrated $\mathfrak{I}$ tweniles.

\author{
DUTY IS SAFETY; \\ (1)
}

TROUBLESOME TOM.

BY MRS. SHERWOOD.

One Volume square $16 \mathrm{mo}$. Illustrated. Price 25 cents.

\section{THINK BEFORE YOU ACT,}

BY MRS. SHERWOOD.

One Volume square $16 \mathrm{mo}$. Illustrated. Price 25 cents

\section{JACK, THE SAILOR BOY,}

BY MRS. SHERWOOD.

One Volume square 16mo. Illustrated. Price 25 cents.

\section{CLEVER STORIES FOR CLEVER BOYS AND GIRLS. CONTAINING}

"Think before you Act," "Jack, the Sailor Boy," "Duty is Safety." One Volume square $16 \mathrm{mo}$. Price 50 cts. 
GEORGE 8. APPLETON'S JUVENILE PUBLICATIONS.

\section{The Jxize story Book; \\ CONSISTING CHIEFLY OF}

TALES TRANSLATED FROM THE GERMAN, FRENCH, AND ITALIAN, TOGETHER WITH

SELECT TALES FROM THE ENGLISH.

Fllustrated with numerous 䀔esigns.

One Volume square $16 \mathrm{mo}$. Half cloth $50 \mathrm{cts}$; cloth extra $63 \mathrm{cts}$.

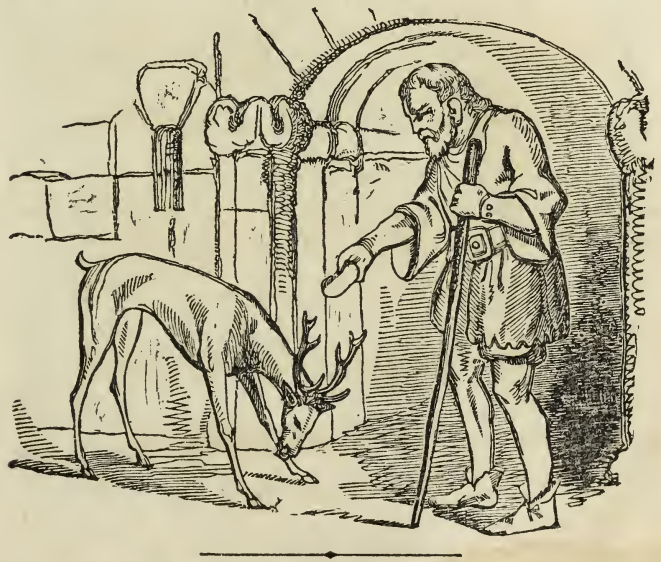

GEORGE'S JOURNEY

TO THE

\section{Land of find $\mathfrak{a} \mathfrak{p} \mathfrak{i} \mathfrak{i} \mathfrak{E} \mathfrak{s}$. BY A LADY.}

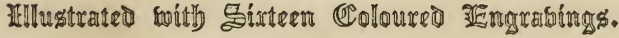

One Volume square $16 \mathrm{mo}$. Price 50 cents. 


\title{
The Book of Animals;
}

INTENDED FOR THE ENTERTAINMENT AND INSTRUCTION

\author{
OF \\ YOUNG PEOPLE. \\ BY R. BILBY.
}

ILLUSTRATED WITH TWELVE DESIGNS OF ANIMALS,

One Volume square $16 \mathrm{mo}$. Price 50 cents.

This volume is intended both as a useful and entertaining book for the young, abounding with Anecdotes of the Quadrupeds, and illustrated with numerous well executed designs.

\section{(⿹勹冫e fappw Children; A TALE OF HOME For}

\section{YOUNG PEOPLE.}

ILLUSTRATED WITH ELEGANT ENGRAVINGS, One Volume square $16 \mathrm{mo}$. Price $50 \mathrm{cts}$.

A very interesting volume for children from six to twelve yeas if age. 
GEORGE S. APPLETON'S JUVENILE PUBLICATIONS.

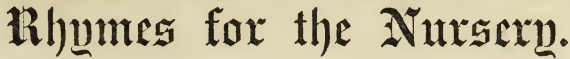

By the Author of "Original Poems."

\section{ILLUSTRATED WITH SIXTEEN DESIGNS.}

One Tolume square $16 \mathrm{mo}$. Price $50 \mathrm{cts}$. plain; $63 \mathrm{cts}$. coloured.

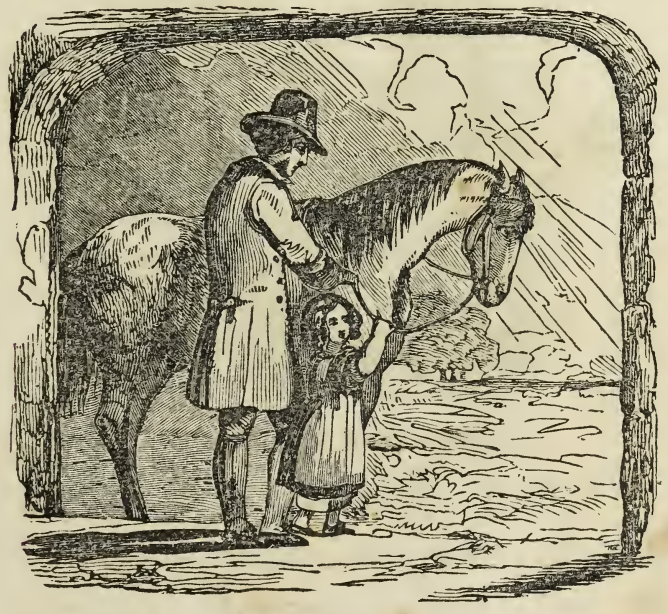

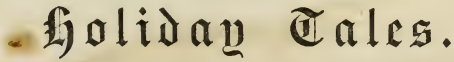

CONTAINING PLEASING STORIES FOR THE YOUNG. PRETTILY ILLUSTRATED.

One Volume square 16 mo. Price in half cloth, 25 cents; cloth gilt, 38 cents. 


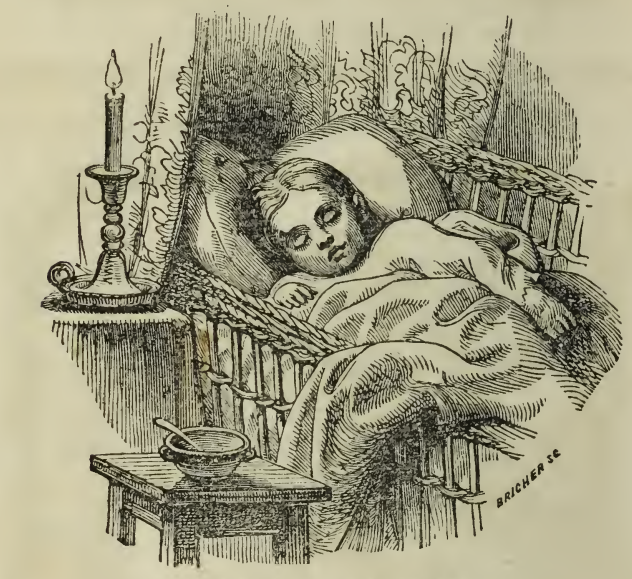

\section{UNCIE JOIIIN \\ Fancy pirture 3 ooks.} IN A NEW AND UNIQUE STYLE,

PUT UP IN DOZENS ASSORTED. SIX KINDS.

\section{CONTENTS.}

UNCLE JOHN'S PICTURE BIBLE ALPHABET.

UNCLE JOHN'S STORY OF BOB.

UNCLE JOHN'S STORY OF DOWNEY THE MOUSE.

UNCLE JOHN'S STORIES OF ANIMALS.

ONCLE JOHN'S BIBLE STORIES.

UNCLE JOHN'S LITTLE RHYMER. 






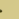


UNIVERSTTY OF ILLINOIS-URBANA 